\title{
Revisiting the genus Cytospora and allied species
}

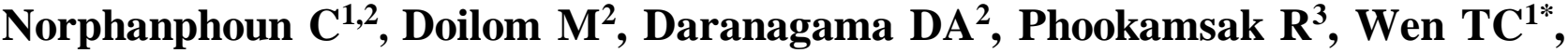 Bulgakov $\mathrm{TS}^{4}$ and Hyde $\mathrm{KD}^{1,2,3}$}

\author{
1 The Engineering Research Center of Southwest Bio-Pharmaceutical Resources, Ministry of Education, Guizhou \\ University, Guiyang, 550025, China \\ ${ }^{2}$ Center of Excellence in Fungal Research, Mae Fah Luang University, Chiang Rai, 57100 Thailand \\ ${ }^{3}$ World Agroforestry Centre, East and Central Asia, 132 Lanhei Road, Kunming 650201, China \\ ${ }^{4}$ Russian Research Institute of Floriculture and Subtropical Crops, 2/28 Yana Fabritsiusa Street, Sochi 354002, \\ Krasnodar region, Russia
}

Norphanphoun C, Doilom M, Daranagama DA, Phookamsak R, Wen TC, Bulgakov TS, Hyde KD 2017 - Revisiting the genus Cytospora and allied species. Mycosphere 8(1), 51-97, Doi 10.5943/mycosphere/8/1/7

\begin{abstract}
Cytospora species are important plant pathogens causing dieback and canker diseases on a wide range of hosts, worldwide. However, species level identification is difficult due to poor phylogenetic understanding and lack of sequenced type species. ITS sequence data are only available for most Cytospora strains in GenBank. In this study, samples of Cytospora were collected from symptomatic twigs and branches in European Russia. A combination of morphological characters and multi-gene phylogenetic analysis (ITS, LSU, RPB2, ACT) were used to identify taxa. A total of 34 collections, representing 17 fungal species of Cytospora were studied. Of these, 14 new species are described and illustrated. Three species were known taxa and identified as $C$. nivea, $C$. parasitica, and $C$. salicicola. Newly introduced species are $C$. ampulliformis, $C$. curvata, $C$. donetzica, C. erumpens, $C$. longiostiolata, C. melnikii, $C$. parakantschavelii, $C$. paratranslucens, $C$. rusanovii, $C$. salicacearum, $C$. salicina, $C$. sorbi, $C$. sorbicola and $C$. ulmi. Descriptions, illustrations and notes are provided for all studied taxa in this study. The distribution patterns of Cytospora species on different hosts are discussed. The study represents a preliminary study of Cytospora species from a small region and provides an initial contribution to the understanding of the genus.
\end{abstract}

Key words - Diaporthales - Morphology - Phylogenetic analyses - Plant pathogenic fungi Russia - Valsaceae

\section{Introduction}

Cytospora was introduced by Ehrenberg (1818) and is one of the most important forest pathogenic genera causing canker disease on branches of various tree species. The disease often leads to large areas of dieback on a wide range of plants (Adams et al. 2005, 2006). Cytospora is the asexual morph of Valsa, which is the type genus of Valsaceae Tul. \& C. Tul. in Diaporthales Nannf. comprising the genera Amphicytostroma, Chadefaudiomyces, Cryptascoma, Cytospora, 
Ditopellina, Durispora, Harpostroma, Hypospilina, Kapooria, Leptosillia, Maculatipalma, Pachytrype and Paravalsa (Adams et al. 2005, Wang et al. 2011, Ariyawansa et al. 2015, Fan et al. 2015a, b, Liu et al. 2015, Maharachchikumbura et al. 2015, 2016, Hyde et al. 2016).

Cytospora has been also considered as the asexual morph of other genera such as, Leucocytospora, Leucostoma, Valsella and Valseutypella (Fries 1823, Saccardo 1884, Gvritishvili 1982, Spielman 1985, Adams et al. 2002, 2005, Castlebury et al. 2002, Bulgakov 2010, Maharachchikumbura et al. 2015, 2016, Rossman et al. 2015, Yang et al. 2015, Li et al. 2016, Hyde et al. 2016). Therefore, all of these sexual genera were synonymized under Valsa, either as a subgenus or species (Adams et al. 2006). The International Code of Nomenclature for Algae, Fungi, and Plants (ICN, McNeill et al. 2012) permits a single name for biological species and genera (Hyde et al. 2009, Wikee et al. 2011, Huang et al. 2013, Wei et al. 2013, Udayanga et al. 2014, Fan et al. 2015a, b). Therefore, Valsa (1849) was treated as synonym of Cytospora (1818), with the latter being the oldest and most widely used name (Adams et al. 2005, Fotouhifar et al. 2010, Fan et al. 2014, Rossman et al. 2015). Most of the names previously recognized in Valsa already have an older epithet in Cytospora in the SMML Fungal Database (http://nt.arsgrin.gov/fungaldatabases/), while some new names for the common species of Cytospora, previously placed in Valsa, were provided by Rossman et al. (2015).

Cytospora species usually produce asexual fruiting bodies and contain a single or labyrinthine of locules, filamentous conidiophores or asci, and allantoid hyaline conidia or allantoid hyaline ascospores (Spielman 1983, 1985, Adams et al. 2005, Fan et al. 2015a, b). In moist conditions, the conidia will emerge from the fruiting bodies forming yellow, orange to red gelatinous tendrils (Adams et al. 2005, 2006). Identification of Cytospora species has generally been established according to host association, while morphological descriptions generally lack significant differences. Therefore, a single species of Cytospora may occur on several unrelated host plants, or a single host plant may support more than one Cytospora species (Adams et al. 2005, Wang et al. 2011, Ariyawansa et al. 2015, Fan et al. 2015a, b, Liu et al. 2015, Hyde et al. 2016). Thus, there are 585 epithets for Cytospora in Index Fungorum (2017) with an estimated number of 110 species in Kirk et al. (2008). However, ex-type sequence data are available for only 23 species in GenBank (accessed 2017). Thus, it is difficult to identify species from a phylogenetic perspective alone (Ariyawansa et al. 2015, Liu et al. 2015, Hyde et al. 2016, Li et al. 2016) as many taxa are morphologically similar. The have been several recent papers dealing with Cytospora with a limited number of multi-gene sequence trees or larger trees based on ITS sequence data, however there has been no comprehensive multi-gene study for the genus (Adams et al. 2002, Fotouhifar et al. 2010, Hyde et al. 2010, 2014, Ariyawansa et al. 2015, Fan et al. 2015a, b, Liu et al. 2015, Yang et al. 2015, Hyde et al. 2016, Li et al. 2016).

The aim of the present study was to identify Cytospora species in a small region of Rusia based on morphological studies and phylogenetic analysis, and provide a multi-locus phylogeny using ITS, LSU, RPB2 and ACT sequence data for resolution of Cytospora species. The distribution of Cytospora species on hosts is also discussed.

\section{Materials \& Methods}

Sample collection and specimen examination

The specimens were collected from Russia during 2015 by Timur Bulgakov. The specimens were returned to the laboratory in small paper bags for observation, examination and description, following the methods described in Norphanphoun et al. (2015, 2016). Micro-morphological characters were studied using a Motic SMZ 168 dissecting microscope. Hand sections of the fruiting structures were mounted in water and examined for morphological details. Specimens were examined under a Nikon Ni compound microscope and photographed using a Canon EOS 600D digital camera fitted to the microscope. Photo-plates were made by using Adobe Photoshop CS6 Extended version $13.0 \times 64$ (Adobe Systems Inc., The United States) and the Tarosoft (R) Image Frame Work program v. 0.9.7 was used for taking measurements. The contents inside the 
conidiomata were picked with a sterile needle and soaked in sterile water in a glass container for examination.

Cultures were obtained by single spore isolation following the method described in Chomnunti et al. (2014). Spore germination was observed and photographed under a Nikon Ni compound microscope fitted with a Canon EOS 600D digital camera. Geminated spores were transferred aseptically to malt extract agar (MEA) and incubated at $18-25^{\circ} \mathrm{C}$. Colony characters were recorded and measured after one week and also one month.

The herbarium specimens were deposited in the Mae Fah Luang University Herbarium, Chiang Rai, Thailand (MFLU) and duplicated in New Zealand Fungal Herbarium, New Zealand (PDD). Living cultures were deposited at Mae Fah Luang University Culture Collection (MFLUCC) and Kunming Culture Collection (KUMCC). Facesoffungi and Index Fungorum numbers were registered (Jayasiri et al. 2015, Index Fungorum 2017).

\section{DNA extraction, PCR amplification and sequencing}

Thirty-four isolates were selected for the molecular analyses (Table 1). DNA was amplified from the complete the internal transcribed spacer regions (ITS1-5.8S-ITS2), large nuclear ribosomal RNA subunit region (LSU), RNA polymerase II subunit (RPB2), and $\alpha$-actin (ACT) genes of each Cytospora isolate, which were performed using fungal mycelia growing on MEA at $18-25^{\circ} \mathrm{C}$ for one month. The genomic DNA was obtained using a E.Z.N.A.TM Fungal DNA MiniKit (Omega Biotech, CA, USA) following the manufacturer's protocols.

Polymerase chain reactions (PCR) were carried out using primer pairs of ITS1 and ITS4 to amplify the ITS region (White et al. 1990), the partial LSU region was amplified with primers NL1 and NL4 (O'Donnell 1993), the partial RPB2 region was amplified using primers bRPB-6F and bRPB-7.1R (Matheny 2005), and the partial ACT region was amplified using primers ACT512F and ACT783R (Carbone \& Kohn 1999) (Table 1). The amplification reaction was performed in 50 $\mu \mathrm{l}$ reaction volume containing, $2 \mu \mathrm{l}$ of DNA template, $2 \mu \mathrm{l}$ of each forward and reverse primers, 25 $\mu$ l of $2 \times$ Bench Top ${ }^{\text {TM }}$ Taq Master Mix (mixture of Taq DNA Polymerase (recombinant): 0.05 units $/ \mu \mathrm{L}, \mathrm{MgCl}_{2}: 4 \mathrm{mM}$, and dNTPs: $\left.0.4 \mathrm{mM}\right)$ and $19 \mu \mathrm{l}$ of double-distilled water $\left(\mathrm{ddH}_{2} \mathrm{O}\right)$. The PCR conditions used in this study for each gene are shown in Table 1 . The quality of PCR products were checked by using $1 \%$ agarose gel electrophoresis stained with ethidium bromide. Purification and sequencing of PCR product were carried out at Life Biotechnology Co., Shanghai, China.

\section{Phylogenetic analysis}

Blast searches were made to identify the closest matches in GenBank and reliable sequences were downloaded (viz. Fotouhifar et al. 2010, Fan et al. 2014, 2015a, b, Hyde et al. 2016). The phylogenetic analyses were initially performed using ITS sequence data and then determined using combined multi-gene phylogeny (ITS, LSU, RPB2, ACT) with 143 and 97 sequences respectively. Cytospora species were selected for combined multi-gene phylogeny based on fungal group relationships between closely related taxa of type strains with our strains from the ITS phylogenetic tree. Phomopsis vaccinii Shear (ATCC 18451) was selected as the outgroup taxon in individual and combined analyses. The individual datasets were combined as this has been previously found to increase phylogenetic accuracy (Cunningham 1997, Bull et al. 1993). The combined sequence alignment was obtained from MEGA7 version 7.0.14 (Kumar et al. 2015) and ambiguously aligned regions were excluded and gaps were treated as missing data. Alignments were checked visually and manually adjusted for errors. The partition homogeneity test (PHT) or the Incongruence Length Difference (ILD) test were used to testing the congruence and combinability of the individual datasets (Farris et al. 1995a, b) with 1,000 heuristic search replicates in PAUP v. $4.0 b 10$ (Swofford 2003). In addition, the datasets were optimized manually where necessary. Phylogenetic trees were reconstructed using maximum parsimony, maximum likelihood and Bayesian inference analyses.

Maximum parsimony (MP) analysis was performed using PAUP (Phylogenetic Analysis Using Parsimony) v. 4.0b10 (Swofford 2003). The trees were inferred using the heuristic search option with tree bisection-reconnection (TBR) as the branch swapping algorithm and 1000 random 
sequence additions. Maxtrees were setup to 1000, branches of zero length were collapsed and all multiple parsimonious trees were saved. Descriptive tree statistics for parsimony tree length (TL), consistency index (CI), retention index (RI), rescaled consistency index (RC) and homoplasy index (HI) were calculated for the maximum parsimonious tree (MPT). The robustness of the most parsimonious trees was evaluated by 1000 bootstrap replications, each with ten replicates of random stepwise addition of taxa (Felsenstein 1985). The Kishino-Hasegawa tests (KHT) (Kishino \& Hasegawa 1989) were performed to determine whether the trees were significantly different.

Table 1 The PCR thermal cycle program in this study

\begin{tabular}{|c|c|c|c|c|}
\hline $\begin{array}{c}\text { Gene and the primers } \\
\text { used }\end{array}$ & Step & Temp & Time & Cycle \\
\hline \multirow{5}{*}{$\begin{array}{c}\text { ITS } \\
\text { ITS1/ITS4 }\end{array}$} & Initialization & $95^{\circ} \mathrm{C}$ & 3 minutes & \multirow{4}{*}{40 Cycles } \\
\hline & Denaturation & $95^{\circ} \mathrm{C}$ & 30 seconds & \\
\hline & Annealing & $55^{\circ} \mathrm{C}$ & 50 seconds & \\
\hline & Extension/Elongation & $72{ }^{\circ} \mathrm{C}$ & 1 minute & \\
\hline & Final Elongation & $72^{\circ} \mathrm{C}$ & 7 minutes & \\
\hline \multirow{5}{*}{$\begin{array}{c}\text { LSU } \\
\text { NL1/NL4 }\end{array}$} & Initialization & $94{ }^{\circ} \mathrm{C}$ & 2 minutes & \multirow{4}{*}{30 Cycles } \\
\hline & Denaturation & $94^{\circ} \mathrm{C}$ & 30 seconds & \\
\hline & Annealing & $52^{\circ} \mathrm{C}$ & 30 seconds & \\
\hline & Extension/Elongation & $72{ }^{\circ} \mathrm{C}$ & 1 minute & \\
\hline & Final Elongation & $72{ }^{\circ} \mathrm{C}$ & 7 minutes & \\
\hline \multirow{5}{*}{$\begin{array}{c}\text { RPB2 } \\
\text { bRPB-6F/ bRPB-7.1R }\end{array}$} & Initialization & $95^{\circ} \mathrm{C}$ & 5 minutes & \multirow{4}{*}{40 Cycles } \\
\hline & Denaturation & $95^{\circ} \mathrm{C}$ & 1 minute & \\
\hline & Annealing & $52{ }^{\circ} \mathrm{C}$ & 2 minutes & \\
\hline & Extension/Elongation & $72^{\circ} \mathrm{C}$ & 90 seconds & \\
\hline & Final Elongation & $72^{\circ} \mathrm{C}$ & 10 minutes & \\
\hline \multirow{5}{*}{$\begin{array}{c}\mathrm{ACT} \\
\text { ACT512F/ACT783R }\end{array}$} & Initialization & $95^{\circ} \mathrm{C}$ & 5 minutes & \multirow{4}{*}{40 Cycles } \\
\hline & Denaturation & $95^{\circ} \mathrm{C}$ & 40 seconds & \\
\hline & Annealing & $58^{\circ} \mathrm{C}$ & 30 seconds & \\
\hline & Extension/Elongation & $72{ }^{\circ} \mathrm{C}$ & 1 minute & \\
\hline & Final Elongation & $72^{\circ} \mathrm{C}$ & 5 minutes & \\
\hline
\end{tabular}

The best-fit nucleotide substitution models for each dataset were separately determined using MrModeltest version 2.2 for both ML and Bayesian analyses (Nylander 2004). Maximumlikelihood (ML) analysis was performed in RAxML (Stamatakis 2006) implemented in raxmlGUI v.1.3 (Silvestro \& Michalak 2012). The 1000 rapid bootstrap replicates were run with generalized time reversible GTRGAMMA model of nucleotide substitution and searches for model selected for ML were applied.

Bayesian inference (BI) analysis was performed using the Markov Chain Monte Carlo (MCMC) method with MrBayes v.3.2.2 (Ronquist et al. 2012). GTR+I+G was selected as the bestfitting model for individual ITS and combined ITS, LSU, RPB2 and ACT. The Markov ChainMonte Carlo sampling (MCMC) analyses, with four chains, were started from random tree topology and lasted 5,000,000 generations and sampled every 100 generations. The Tracer v. 1.5.0 program was used to check the effective sampling sizes (ESS) that should be above 200, the stable likelihood plateaus and burn-in value (Rambaut et al. 2013). The first 5000 generations were excluded as burn-in.

The resulting trees were viewed with FigTree v1.4.0 (Rambaut 2012) and edited in Adobe Illustrator CS6 and Adobe Photoshop CS6 Extended version 13.0 × 64 (Adobe Systems Inc., The United States). Sequences data from this study were deposited in GenBank (Table 2) and alignments were saved in TreeBASE (www.treebase.org) submission ID: 20491 (ITS sequence alignment) and 20492 (combined sequence alignment). 
Table 2 Cytospora species introduced in this study (ex-type strains are bold)

\begin{tabular}{|c|c|c|c|c|c|c|c|}
\hline \multirow{2}{*}{ NO } & \multirow{2}{*}{ TAXON } & \multirow{2}{*}{ STRAIN } & \multirow{2}{*}{ HOST } & \multicolumn{4}{|c|}{ GENBANK ACCESSION NUMBERS } \\
\hline & & & & ITS & LSU & RPB2 & ACT \\
\hline 1 & Cytospora ampulliformis & MFLUCC 16-0583 & Sorbus intermedia (Ehrh.) Pers. & KY417726 & KY417760 & KY417794 & KY417692 \\
\hline 2 & Cytospora ampulliformis & MFLUCC 16-0629 & Acer platanoides $\mathrm{L}$. & KY417727 & KY417761 & KY417795 & KY417693 \\
\hline 3 & Cytospora curvata & MFLUCC 15-0865 & Salix alba $\mathrm{L}$ & KY417728 & KY417762 & KY417796 & KY417694 \\
\hline 4 & Cytospora donetzica & MFLUCC 15-0864 & Crataegus monogyna Jacq. & KY417729 & KY417763 & KY417797 & KY417695 \\
\hline 5 & Cytospora donetzica & MFLUCC 16-0641 & Pyrus pyraster (L.) Burgsd & KY417730 & KY417764 & KY417798 & KY417696 \\
\hline 6 & Cytospora donetzica & MFLUCC 16-0574 & Rosa sp. & KY417731 & KY417765 & KY417799 & KY417697 \\
\hline 7 & Cytospora donetzica & MFLUCC 16-0589 & Salix alba $\mathrm{L}$ & KY417732 & KY417766 & KY417800 & KY417698 \\
\hline 8 & Cytospora erumpens & MFLUCC 16-0580 & Salix $\times$ fragilis $\mathrm{L}$. & KY417733 & KY417767 & KY417801 & KY417699 \\
\hline 9 & Cytospora longiostiolata & MFLUCC 16-0628 & Salix $\times$ fragilis $\mathrm{L}$ & KY417734 & KY417768 & KY417802 & KY417700 \\
\hline 10 & Cytospora melnikii & MFLUCC 15-0851 & Malus domestica Borkh & KY417735 & KY417769 & KY417803 & KY417701 \\
\hline 11 & Cytospora melnikii & MFLUCC 16-0635 & Populus nigra $L$. var. italica Münchh & KY417736 & KY417770 & KY417804 & KY417702 \\
\hline 12 & Cytospora nivea & MFLUCC 15-0860 & Salix acutifolia Willd. & KY417737 & KY417771 & KY417805 & KY417703 \\
\hline 13 & Cytospora parakantschavelii & MFLUCC 15-0857 & Populus $\times$ sibirica G.V. Krylov \& G.V. Grig. ex A.K. Skvortsov & KY417738 & KY417772 & KY417806 & KY417704 \\
\hline 14 & Cytospora parakantschavelii & MFLUCC 16-0575 & Pyrus pyraster $($ L.) Burgsd. & KY417739 & KY417773 & KY417807 & KY417705 \\
\hline 15 & Cytospora parasitica & MFLUCC 16-0507 & Malus domestica Borkh & KY417740 & KY417774 & KY417808 & KY417706 \\
\hline 16 & Cytospora paratranslucens & MFLUCC 16-0506 & Populus alba L. var. bolleana (Lauche) Otto & KY417741 & KY417775 & KY417809 & KY417707 \\
\hline 17 & Cytospora paratranslucens & MFLUCC 16-0627 & Populus alba $\mathrm{L}$. & KY417742 & KY417776 & KY417810 & KY417708 \\
\hline 18 & Cytospora rusanovii & MFLUCC 15-0853 & Populus $\times$ sibirica G.V. Krylov \& G.V. Grig. ex A.K. Skvortsov & KY417743 & KY417777 & KY417811 & KY417709 \\
\hline 19 & Cytospora rusanovii & MFLUCC 15-0854 & Salix babylonica $\mathrm{L}$. & KY417744 & KY417778 & KY417812 & KY417710 \\
\hline 20 & Cytospora salicacearum & MFLUCC 15-0861 & Salix $\times$ fragilis $\mathrm{L}$ & KY417745 & KY417779 & KY417813 & KY417711 \\
\hline 21 & Cytospora salicacearum & MFLUCC 16-0509 & Salix alba $\mathrm{L}$ & KY417746 & KY417780 & KY417814 & KY417712 \\
\hline 22 & Cytospora salicacearum & MFLUCC 16-0576 & Populus nigra L. var. italica Münchh. & KY417747 & KY417781 & KY417815 & KY417713 \\
\hline 23 & Cytospora salicacearum & MFLUCC 16-0587 & Prunus cerasus $\mathrm{L}$. & KY417748 & KY417782 & KY417816 & KY417714 \\
\hline 24 & Cytospora salicicola & MFLUCC 15-0866 & Salix alba $\mathrm{L}$. & KY417749 & KY417783 & KY417817 & KY417715 \\
\hline 25 & Cytospora salicina & MFLUCC 15-0862 & Salix alba $\mathrm{L}$. & KY417750 & KY417784 & KY417818 & KY417716 \\
\hline 26 & Cytospora salicina & MFLUCC 16-0637 & Salix $\times$ fragilis $\mathrm{L}$. & KY417751 & KY417785 & KY417819 & KY417717 \\
\hline 27 & Cytospora sorbi & MFLUCC 16-0631 & Sorbus aucuparia L. & KY417752 & KY417786 & KY417820 & KY417718 \\
\hline 28 & Cytospora sorbicola & MFLUCC 16-0581 & Sorbus aucuparia $\mathrm{L}$. & KY417753 & KY417787 & KY417821 & KY417719 \\
\hline 29 & Cytospora sorbicola & MFLUCC 16-0582 & Cotoneaster melanocarpus Fisch. ex Blytt, & KY417754 & KY417788 & KY417822 & KY417720 \\
\hline 30 & Cytospora sorbicola & MFLUCC 16-0584 & Acer pseudoplatanus $\mathrm{L}$. & KY417755 & KY417789 & KY417823 & KY417721 \\
\hline 31 & Cytospora sorbicola & MFLUCC 16-0585 & Sorbaronia mitschurinii (A.K. Skvortsov \& Maitul.) Sennikov & KY417756 & KY417790 & KY417824 & KY417722 \\
\hline 32 & Cytospora sorbicola & MFLUCC 16-0586 & Prunus cerasus $\mathrm{L}$. & KY417757 & KY417791 & KY417825 & KY417723 \\
\hline 33 & Cytospora sorbicola & MFLUCC 16-0633 & Cotoneaster melanocarpus Fisch. ex Blytt & KY417758 & KY417792 & KY417826 & KY417724 \\
\hline 34 & Cytospora ulmi & MFLUCC 15-0863 & Ulmus minor Mill. & KY417759 & KY417793 & KY417827 & KY417725 \\
\hline
\end{tabular}




\section{Results}

Phylogenetic analyses

The individual ITS dataset contained 143 sequences. The total alignment length had 609 total characters including alignment gaps. Parsimony analyses indicate that 391 characters were constant, 72 variable characters were parsimony uninformative and 146 characters were parsimony informative. The parsimony analysis of the data matrix resulted in 1000 equally parsimonious trees and the first tree $(\mathrm{TL}=773, \mathrm{CI}=0.4373, \mathrm{RI}=0.8446, \mathrm{RC}=$ $0.3693, \mathrm{HI}=0.5627$ ) is shown in Fig. 1. Based on MP, ML and BI analyses of individual ITS dataset can separate some species of Cytospora (Fig. 1). However, it cannot resolve some species. For example C. longiostiolata (MFLUCC 16-0628), C. melnikii (MFLUCC 15-0851, MFLUCC 16-0635), C. salicacearum (MFLUCC 16-0509, MFLUCC 16-0576, MFLUCC 16-0587, MFLUCC 15-0861), C. salicina (MFLUCC 15-0862, MFLUCC 16-0637), C. chrysosperma (334, CFCC 89629, CFCC 89630, HMBF CGHs10, HMBF 151, HMBF 158, HMBF 17) and Cytospora sp. (30 NC5, 37 NC14) (Fig. 1). Thus, a combined ITS, LSU, RPB2 and ACT tree was used to delimit the Cytospora species. The combined ITS, LSU, RPB2 and ACT analysis comprised 97 sequences. The total alignment length of 2337 characters including alignment gaps was used of which 609, 610-1163, 1164-2044 and 2045-2337 were derived from ITS, LSU, RPB2 and ACT sequence data respectively. The result from the partition homogeneity test (PHT) was not significant level (95\%), indicating that the individual data sets were congruent and could be combined. Parsimony analysis indicate that 1545 characters were constant, 240 variable characters were parsimony uninformative and 552 characters were parsimony informative and yielded 1000 most parsimonious trees $(\mathrm{TL}=2020, \mathrm{CI}=0.554, \mathrm{RI}=0.864, \mathrm{RC}=0.479, \mathrm{HI}=0.446$ ) (Fig. 2 ). The BI and ML tree analyses of individual and combined phylogenies had similar topologies to the MP tree as shown in Figs. 1 and 2 respectively. Bootstrap support values of MP, ML $(\geq 70 \%)$ and Bayesian posterior probabilities $(\geq 0.90)$ are shown on the upper branches (Figs. 1 and 2). The molecular support obtained from phylogenetic topologies are discussed under notes of each species.

\section{Taxonomy}

In this study, we introduce 14 new species and re-describe three known species. We follow Jeewon and Hyde (2016) for establishing species boundaries and Dayarathne et al. (2016) for using old names.

Cytospora ampulliformis Norphanphoun, Bulgakov, T.C. Wen \& K.D. Hyde, sp. nov. Index Fungorum number: IF552601, Facesoffungi Number: FoF 02736 Etymology: The specific epithet 'ampulliformis' refers to the flask-shaped conidiogenous cells.

\section{Holotype: MFLU 15-2187}

Associated with twigs and branches of Sorbus intermedia (Ehrh.) Pers. Sexual morph: Undetermined. Asexual morph: Conidiomata 680-1200 × 350-480 $\mu \mathrm{m}$ diameter, semiimmersed in host tissue, solitary, erumpent, scattered, discoid, circular to ovoid, with 3-4 locules, and ostiolar neck. Ostioles 200-300 $\mu \mathrm{m}$ long, at the same level as the disc surface. Peridium comprising few to several layers of cells of textura angularis, with inner most layer thin, hyaline to pale brown, outer layer brown to dark brown. Conidiophores unbranched, reduced to conidiogenous cells. Conidiogenous cells blastic, enteroblastic, flask-shaped phialidic, formed from the inner most layer of pycnidial wall, hyaline, smooth-walled. Conidia (5-)5.6-9 × 1.3-1.6(-1.7) $\mu \mathrm{m}(\overline{\mathrm{x}}=7.5 \times 1.6 \mu \mathrm{m}, \mathrm{n}=30)$, unicellular, subcylindrical, hyaline, smooth-walled. 
Culture characteristics - Colonies on MEA, reaching $7.5 \mathrm{~cm}$ diameter after 7 days at $25^{\circ} \mathrm{C}$, producing dense mycelium, circular, margin rough, white, lacking aerial mycelium.

Material examined - RUSSIA, Rostov Region, Rostov-on-Don City, Botanical Garden of Southern Federal University, Systematic Arboretum, parkland, dead and dying branches (necrotrophic) of Sorbus intermedia (Rosaceae), 30 May 2015, T. Bulgakov, T-483 (MFLU 15-2187, holotype, KUN, isotype), ex-type living culture, MFLUCC 16-0583, KUMCC; RUSSIA, Rostov Region, Krasnosulinsky District, Donskoye Forest, artificial forest, dying twigs and branches (necrotrophic) on Acer platanoides L. (Sapindaceae), 27 October 2015, T. Bulgakov, T-1094 (MFLU 15-3756, KUN), living culture, MFLUCC 160629, KUMCC.

Notes - Cytospora species associated with Sorbus sp. were reported in previous studies such as C. leucostoma and Valsa massariana (Adams et al. 2002, 2005). In this study, C. ampulliformis, C. sorbi and C. sorbicola are also reported from Sorbus sp. (Table 3). Morphologically, $C$. ampulliformis is similar to $C$. sorbi in its conidiomata having 3-4 locules and in the length of ostiolar neck (C. ampulliformis: $200-300 \mu \mathrm{m}$ versus $250-300$ $\mu \mathrm{m}$ : $C$. sorbi). However, $C$. ampulliformis differs from $C$. sorbi in having larger conidia $(C$. ampulliformis: $7.5 \times 1.6 \mu \mathrm{m}$, versus $6.5 \times 1.5 \mu \mathrm{m}$ : $C$. sorbi). Based on phylogenetic analyses, both species form separate lineages within the genus Cytospora (Figs. 1 and 2).

We obtained two isolates of Cytospora ampulliformis (MFLUCC 16-0583, MFLUCC 16-0629) and these formed a close relationship with C. cotini (MFLUCC 14-1050) isolated from Cotinus coggygria, C. tanaitica (MFLUCC 14-1057) isolated from Betula pubescens, C. rosarum (218) isolated from Rosa canina and C. ulmi (MFLUCC 15-0863) isolated from Ulmus minor. Cytospora ampulliformis $(7.5 \times 1.6 \mu \mathrm{m})$ differs from $C$. cotini in forming black-discoid conidiomata on the host and lobate circular colonies on MEA (Hyde et al. 2016), while it differs from $C$. cotini $(5.9 \times 1.2 \mu \mathrm{m})$, C. tanatica $(3.4 \times 0.7 \mu \mathrm{m})$, C. rosarum $(5-6 \times 1.5 \mu \mathrm{m})$ and $C$. ulmi $(5.4 \times 1.4 \mu \mathrm{m})$ by its larger conidia.

Cytospora curvata Norphanphoun, Bulgakov, T.C. Wen \& K.D. Hyde, sp. nov.

Index Fungorum number: IF552602, Facesoffungi Number: FoF 02737

Fig. 4

Etymology: The specific epithet "curvata" refers to the conidia character (Latin 'curvata' means 'crooked', 'bent', 'curved').

Holotype: MFLU 15-2229

Associated with twigs and branches of Salix alba L. Sexual morph: Undetermined. Asexual morph: Conidiomata 900-1100 × 470-580 $\mu \mathrm{m}$ diameter, semi-immersed in host tissue, scattered, erumpent, unilocular, with ostiolar neck. Ostioles 140-160 $\mu \mathrm{m}$, same level as the disc surface. Peridium comprising a few to several layers of cells of textura angularis, with inner most layer thin, brown, outer later dark brown to black. Conidiophores unbranched, reduced to conidiogenous cells. Conidiogenous cells blastic, enteroblastic, phialidic, formed from the inner most layer of pycnidial wall, hyaline, smooth-walled. Conidia $(5.4-) 5.8-7.7 \times 1.2-1.3(-1.4) \mu \mathrm{m}(\overline{\mathrm{x}}=5.9 \times 1.3 \mu \mathrm{m}, \mathrm{n}=30)$, unicellular, elongateallantoid, slightly curved, hyaline, smooth-walled.

Culture characteristics - Colonies on MEA, reaching $8 \mathrm{~cm}$ diameter after 7 days at 25 ${ }^{\circ} \mathrm{C}$, producing dense mycelium, circular, white, margin rough, lacking aerial mycelium.

Material examined - RUSSIA, Rostov Region, Krasnosulinsky District, Donskoye Forest, shore of little pond, on dead and dying branches of Salix alba (Salicaceae), 28 June 2015, T. Bulgakov, T-525 (MFLU 15-2229, holotype, KUN, isotype), ex-type living culture, MFLUCC 15-0865, KUMCC. 


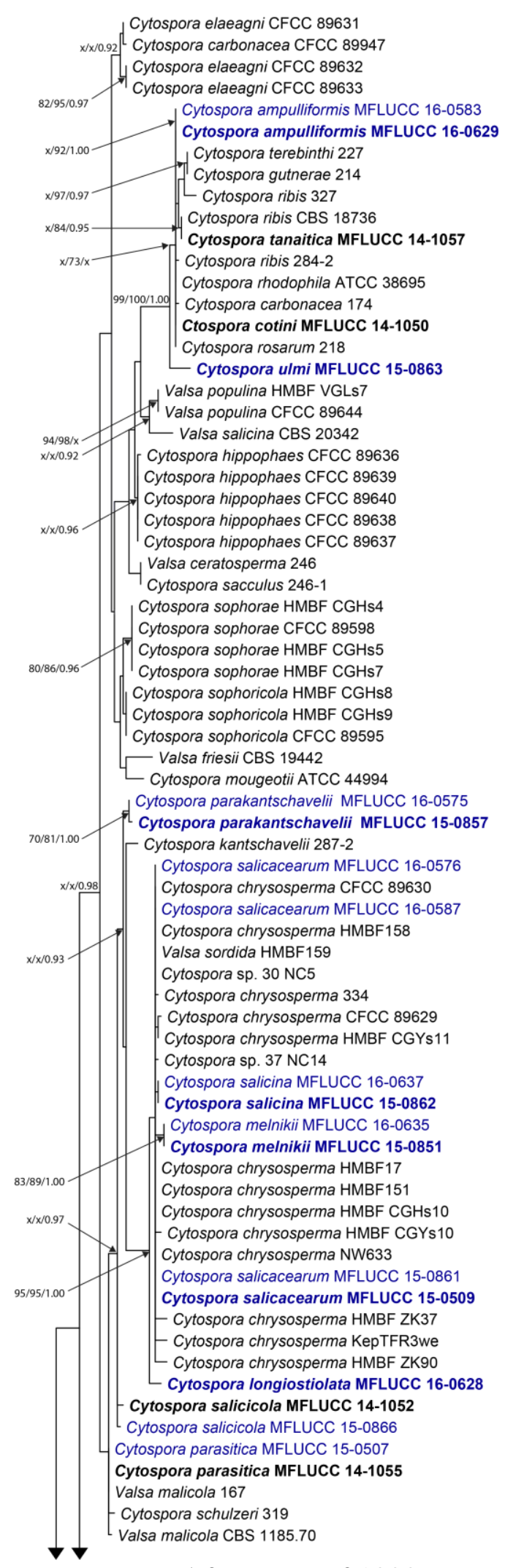

Fig. 1 - Phylogram generated from one of 1000 most parsimonious trees based on analysis of ITS sequence data of Cytospora isolates. The tree is rooted to Phomopsis vaccinii (ATCC 18451). Maximum parsimony and maximum likelihood bootstrap values $\geq 70 \%$, Bayesian posterior probabilities $\geq 0.90$ (MPBS/MLBS/PP) are given at the nodes. The species obtained in this study are in blue and ex-types from the study are in blue bold. Ex-type taxa from other studies are in black bold. 


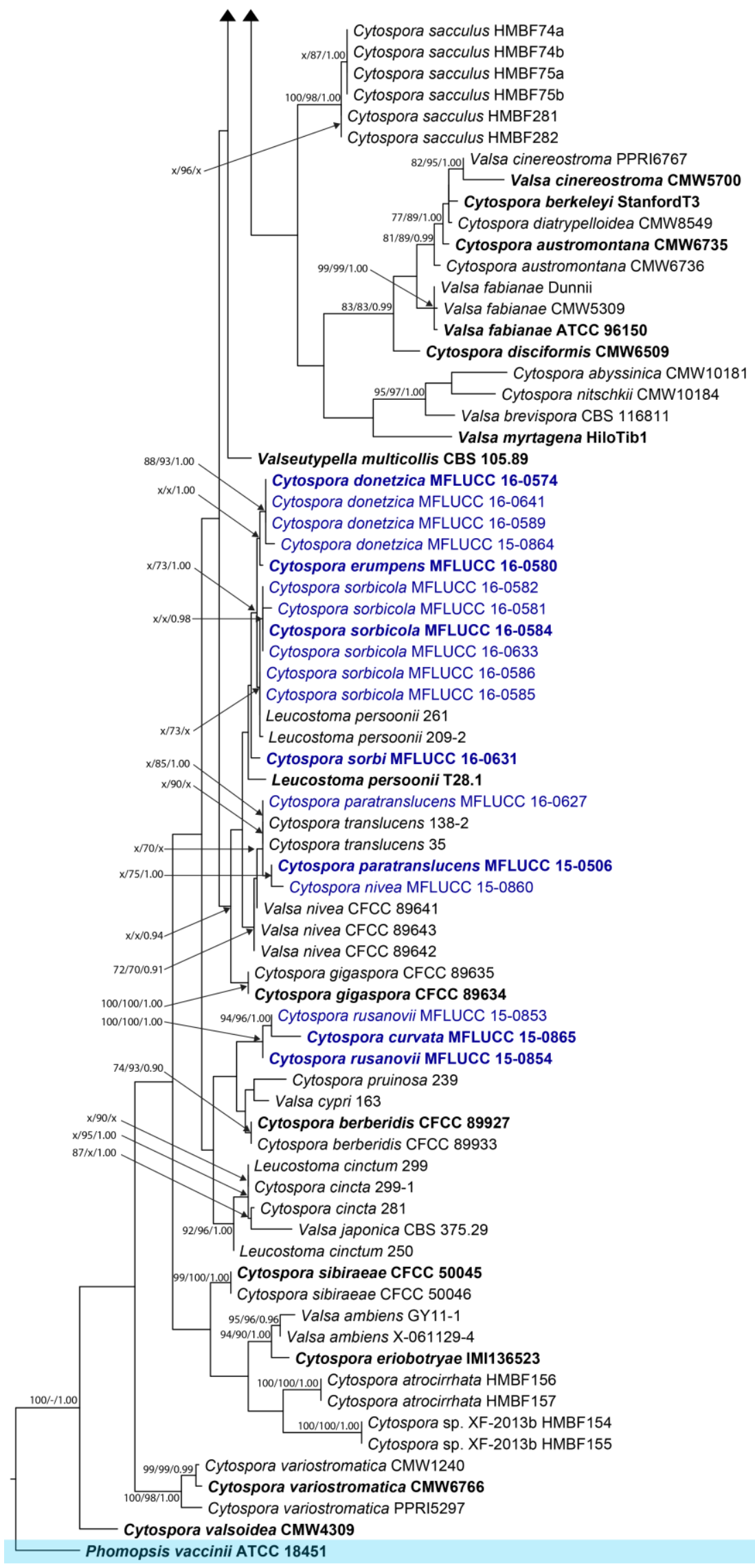

Cytospora valsoidea CMW430

Fig. 1 - continued

20.0 


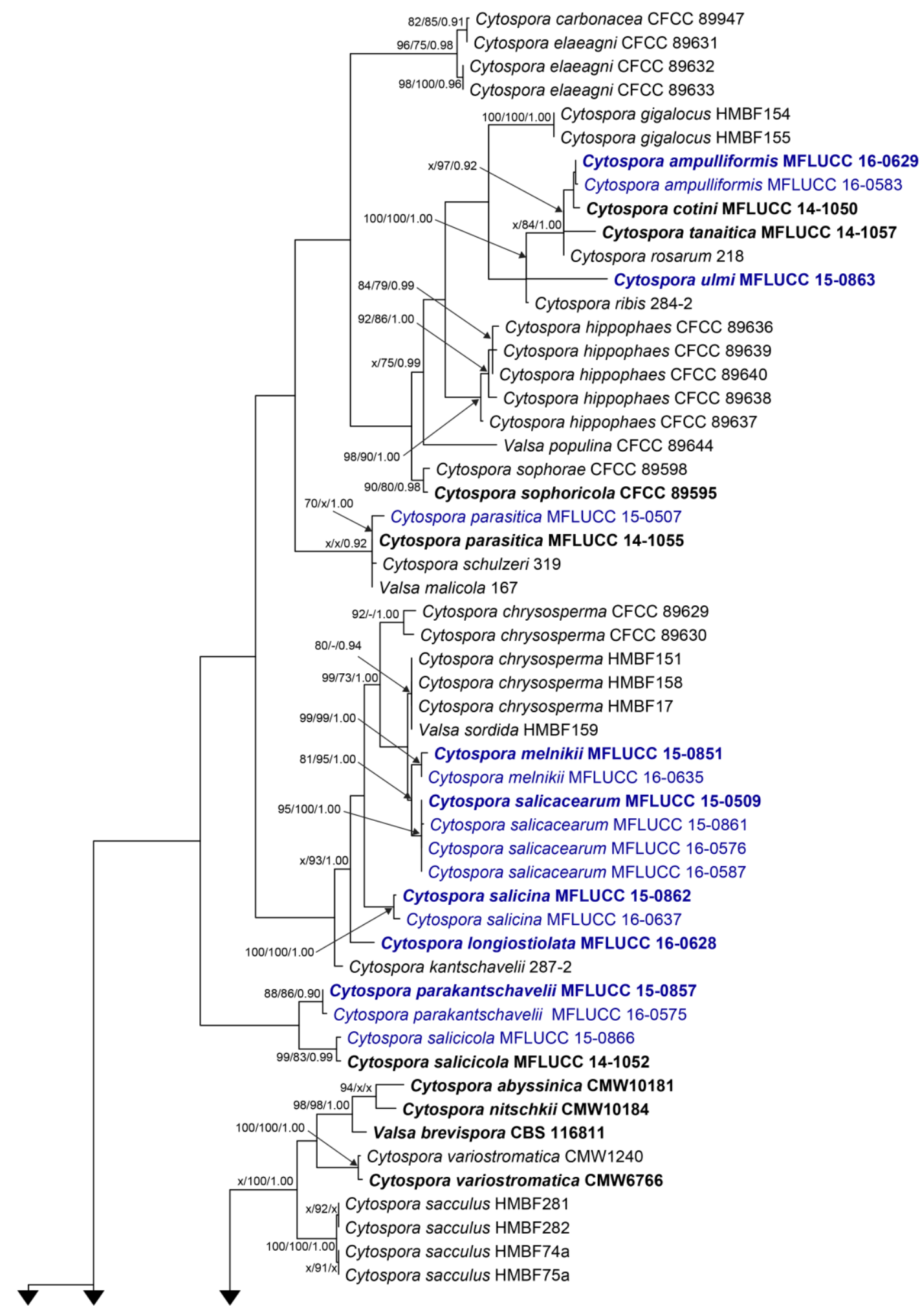

Fig. 2 - Phylogram generated from one of 1000 most parsimonious trees based on analysis of combined ITS, LSU, RPB2 and ACT sequence data of Cytospora isolates. The tree is rooted to Phomopsis vaccinii (ATCC 18451). Maximum parsimony and maximum likelihood bootstrap values $\geq 70 \%$, Bayesian posterior probabilities $\geq 0.90$ (MPBS/MLBS/PP) are given at the nodes. The species obtained in this study are in blue and ex-types from the study are in blue bold. Ex-type taxa from other studies are in black bold. 


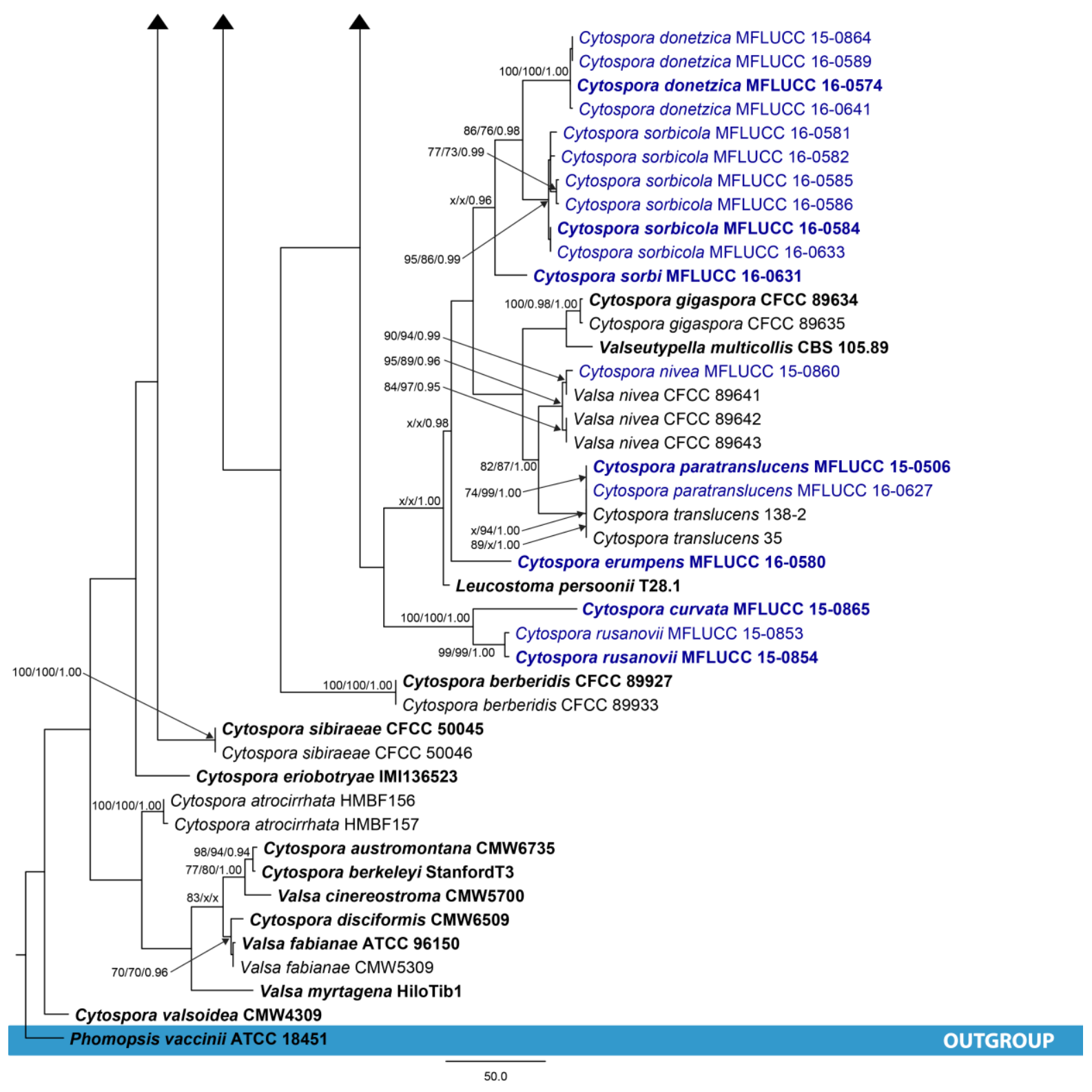

Fig. 2 continued

Notes - Many Cytospora species have been reported from Salix worldwide (Table 3; Adams et al. 2002, 2005, 2006, Défago 1942, Fotouhifar et al. 2010, Singh et al. 2007). However, they can be distinguished based on phylogenetic analyses (Fan et al. 2014, Wang et al. 2015). Ten novel species are introduced in this study, which were collected from Salix viz. $C$. curvata, $C$. donetzica, $C$. erumpens, $C$. longiostiolata, $C$. rusanovii, $C$. salicacearum, $C$. salicina, $C$. salicacearum, $C$. salicicola and $C$. salicina. Cytospora curvata is most similar to C. longiostiolata (MFLUCC 16-0628), but the former species differs in having shorter ostiolar necks (C. curvata: $140-160 \mu \mathrm{m}$ versus $400-500 \mu \mathrm{m}: C$. longiostiolata) and larger conidia (C. curvata: $5.9 \times 1.3 \mu \mathrm{m}$ versus $5.5 \times 1.3 \mu \mathrm{m}$ : C. longiostiolata).

Phylogenetic analysis of combined ITS, LSU, RPB2 and ACT sequence data indicate that Cytospora curvata (MFLUCC 15-0865) forms a separate branch as a sister taxon to C. rusanovii (MFLUCC 15-0853, MFLUCC 15-0854) (Figs. 1 and 2). Cytospora rusanovii is reported in this study, also from Salix. Cytospora rusanovii differs from $C$. curvata in having conidiomata with 4-6 locules, long ostioles $(410-450 \mu \mathrm{m})$, branched conidiophores and conidia that are shorter and wider $(5.4 \times 1.4 \mu \mathrm{m})$ than $C$. curvata. 
In ITS, Cytospora rusanovii differs from $C$. curvata at six polymorphisms, in ACT, they are different at six polymorphisms. Thus, based on phylogenetic analysis, polymorphic nucleotide comparisons and morphological differences, $C$. melnikii it is considered as a novel species.
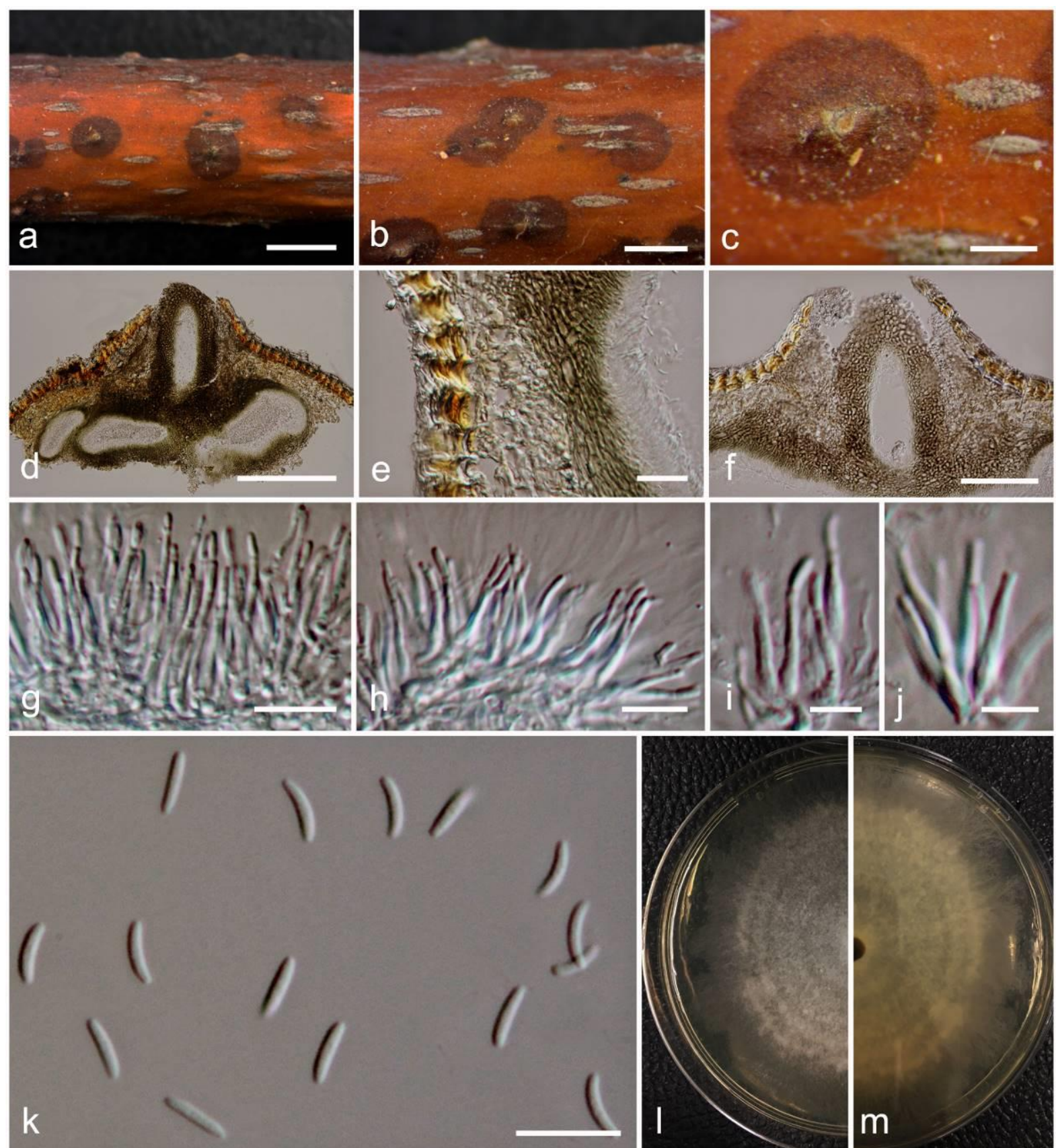

Fig. 3 - Cytospora ampulliformis on Sorbus intermedia (MFLU 15-2187, holotype). a Stromatal habit in wood. b Fruiting bodies on substrate. c Surface of fruiting bodies. d Cross section of the stroma showing conidiomata. e Peridium. f Ostiolar neck. g-j Conidiogenous cells with attached conidia. $\mathrm{k}$ Mature conidia. $1, \mathrm{~m}$ Colonies on MEA (l-from above, $\mathrm{m}$-from below). Scale bars: $\mathrm{a}=2000 \mu \mathrm{m}, \mathrm{b}=1000 \mu \mathrm{m}, \mathrm{c}=500 \mu \mathrm{m}, \mathrm{d}, \mathrm{f}=200 \mu \mathrm{m}, \mathrm{e}=50 \mu \mathrm{m}, \mathrm{f}=200$ $\mu \mathrm{m}, \mathrm{g}, \mathrm{h}, \mathrm{k}=10 \mu \mathrm{m}, \mathrm{i}, \mathrm{j}=5 \mu \mathrm{m}$.

Cytospora donetzica Norphanphoun, Bulgakov, T.C. Wen \& K.D. Hyde, sp. nov. Index Fungorum number: IF552603, Facesoffungi Number: FoF 02738 
Etymology: The specific epithet "donetzica" refers to biogeographical region of Donets ridge (Donets highland) and Seversky Donets river basin, where the type specimens were collected.

Holotype: MFLU 15-2093
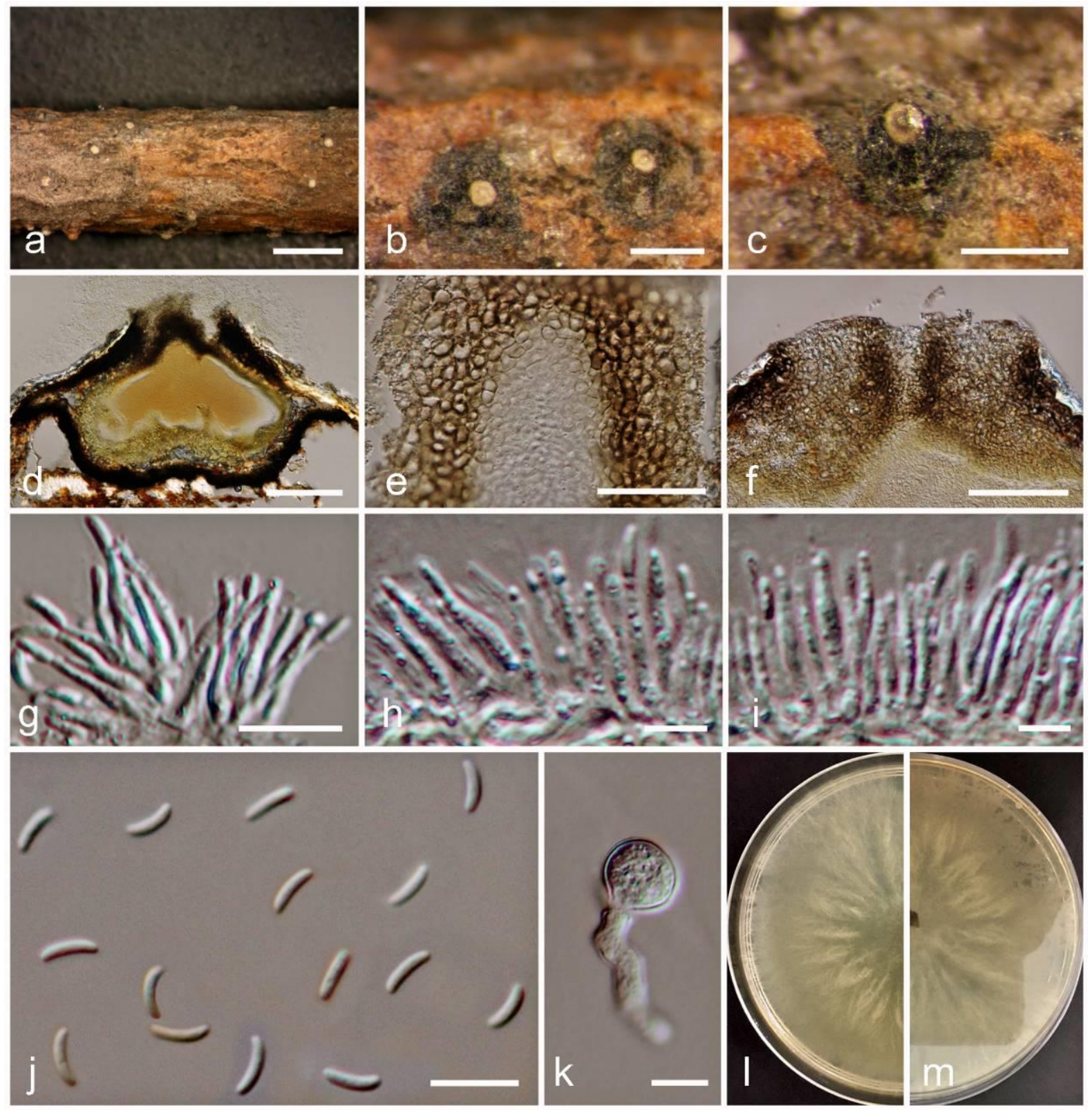

Fig. 4 - Cytospora curvata on Salix alba (MFLU 15-2229, holotype). a Stromatal habit in wood. b Fruiting bodies on substrate. c Surface of fruiting bodies. d Cross section of the stroma showing conidiomata. e Peridium. f Ostioles. g-i Conidiogenous cells with attached conidia. $\mathrm{j}$ Mature conidia. $\mathrm{k}$ Germinating spore. $1, \mathrm{~m}$ Colonies on MEA (l-from above, $\mathrm{m}$ from below). Scale bars: $\mathrm{a}=2000 \mu \mathrm{m}, \mathrm{b}, \mathrm{c}=500 \mu \mathrm{m}, \mathrm{d}=200 \mu \mathrm{m}, \mathrm{e}=50 \mu \mathrm{m}, \mathrm{f}=100 \mu \mathrm{m}, \mathrm{g}$, $\mathrm{j}, \mathrm{k}=10 \mu \mathrm{m}, \mathrm{h}, \mathrm{i}=5 \mu \mathrm{m}$.

Associated with twigs and branches of Crataegus monogyna Jacq., Pyrus pyraster (L.) Burgsd., Rosa sp. and Salix alba. Sexual morph: Undetermined. Asexual morph: Conidiomata 800-1200 $\times 480-560 \mu \mathrm{m}$ diameter, semi-immersed in host tissue, scattered, with 3-4 locules, with ostiolate. Ostioles $150-250 \mu \mathrm{m}$ diameter, at the same level as the disc surface. Peridium comprising a few to several layers of cells of textura angularis, with inner 
most layer thin, pale brown, outer later brown. Conidiophores branched, reduced to conidiogenous cells. Conidiogenous cells blastic, enteroblastic, phialidic, formed from the inner most layer of pycnidial wall, hyaline, smooth-walled. Conidia (4.6-)5.4-6.4 $\times 1.2-1.4(-$ 1.6) $\mu \mathrm{m}(\overline{\mathrm{x}}=5.5 \times 1.4 \mu \mathrm{m}, \mathrm{n}=30)$, unicellular, elongate-allantoid, slightly curved, hyaline, smooth-walled.

Culture characteristics - Colonies on MEA, reaching $7 \mathrm{~cm}$ diameter after 7 days at 25 ${ }^{\circ} \mathrm{C}$, producing dense mycelium, circular, margin rough, white, with aerial mycelium.

Material examined - RUSSIA, Rostov Region, Shakhty City, Grushevka steppe slopes near Grushevsky pond, ravine shrubbery, on dead and dying branches of Rosa sp. (Rosaceae), 14 May 2015, T. Bulgakov, T-389 (MFLU 15-2093, holotype, KUN, isotype), ex-type living culture, MFLUCC 16-0574, KUMCC; RUSSIA, Rostov Region, Krasnosulinsky District, Donskoye forestry, stony steppe, on dead and dying branches of Crataegus monogyna (Rosaceae), 28 June 2015, T. Bulgakov, T-523 (MFLU 15-2227, KUN), living culture, MFLUCC 15-0864, KUMCC; RUSSIA, Rostov Region, Krasnosulinsky District, Donskoye forestry, riparian forestry, on dead and dying branches of Salix alba (Salicaceae), 18 June 2015, T. Bulgakov, T-343 (MFLU 15-2047, KUN), living culture, MFLUCC 16-0589, KUMCC; RUSSIA, Rostov Region, Krasnosulinsky District, Donskoye forestry, ravine forest, on dying twigs and branches of Pyrus pyraster (Rosaceae), 27 October 2015, T. Bulgakov, T-1102 (MFLU 15-3764, KUN), living culture, MFLUCC 16-0641, KUMCC.

Notes - We observed four isolates of Cytospora donetzica (MFLUCC 16-0574, MFLUCC 15-0864, MFLUCC 16-0589, MFLUCC 16-0641) which clustered on a relative independent branch with high bootstrap support (100\% MP/ 100\% ML/ 1.00 PP, Fig. 2). The new species is introduced with the type from Rosa sp. Cytospora donetzica is most similar to C. ceratosperma (Tode) G.C. Adams \& Rossman in its conidia size $(5.5 \times 1.4 \mu \mathrm{m}$ versus $5-6$ $\times 1.4 \mu \mathrm{m}$ ) (Saccardo 1884). However, based on combined gene phylogenetic analysis, $C$. donetzica is clearly separated from $C$. ceratosperma and sister to $C$. sorbicola with high bootstrap support (86\% MP/76\% ML/0.98 PP) (Fig. 2). In the polymorphic nucleotides of ITS, RPB2 and ACT sequence data, $C$. donetzica differs from $C$. sorbicola with five ITS polymorphisms, 23 RPB2 polymorphisms and seven ACT polymorphisms. Thus, $C$. donetzica is considered as a novel species.

Cytospora erumpens Norphanphoun, Bulgakov, T.C. Wen \& K.D. Hyde, sp. nov.

Index Fungorum number: IF552604, Facesoffungi Number: FoF 02739

Fig. 6

Etymology: The specific epithet 'erumpens' refers to the conidiomata characteristic as erumpent.

Holotype: MFLU 15-2165

Associated with twigs and branches of Salix $\times$ fragilis L. [S. alba L. $\times$ S. euxina I.V. Belyaeva]. Sexual morph: Undetermined. Asexual morph: Conidiomata 720-1000 × 470-550 $\mu \mathrm{m}$ diameter, semi-immersed in host tissue, solitary, erumpent, with 1-3 locules, with ostiolar neck. Ostioles 280-350 $\mu \mathrm{m}$, at the same level as the disc surface. Peridium comprising a few to several layers of cells of textura angularis, with inner layer thin, pale brown, outer later brown to dark brown. Conidiophores unbranched or occasionally branched at the base, reduced to conidiogenous cells. Conidiogenous cells blastic, enteroblastic, phialidic, formed from the inner most layer of pycnidial wall, hyaline, smooth-walled. Conidia (5.6-)6.4-6.7 ×1.3-1.4(-1.7) $\mu \mathrm{m}(\overline{\mathrm{x}}=6.4 \times 1.5 \mu \mathrm{m}, \mathrm{n}=30)$, unicellular, elongateallantoid, hyaline, thin-walled, smooth-walled.

Culture characteristics - Colonies on MEA, reaching $8.5 \mathrm{~cm}$ diameter after 7 days at $25^{\circ} \mathrm{C}$, producing dense mycelium, circular, margin rough, white, lacking aerial mycelium. 
Material examined - RUSSIA, Rostov Region, Shakhty City, Grushevka steppe slopes, near Grushevsky pond, osier-bed near pond, on dead and dying branches of Salix $\times$ fragilis L. [S. alba L. $\times$ S. euxina I.V. Belyaeva]. (Salicaceae), 14 May 2015, T. Bulgakov, T-461 (MFLU 15-2165, holotype, PDD isotype), ex-type living culture, MFLUCC 16-0580, KUMCC.

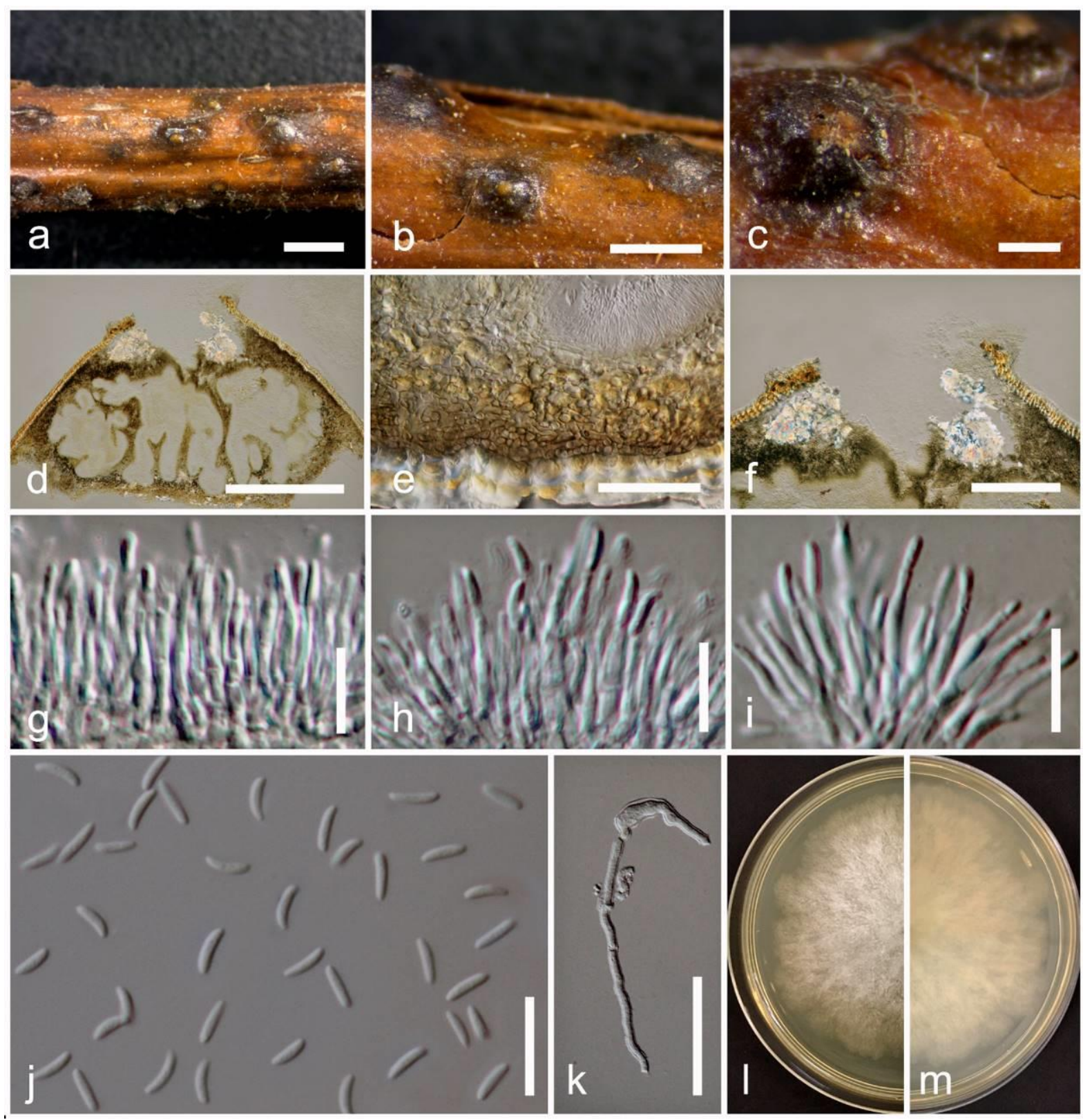

Fig. 5 - Cytospora donetzica on Rosa sp. (MFLU 15-2093, holotype). a Stromatal habit in wood. b Fruiting bodies on substrate. c Surface of fruiting bodies. d Cross section of the stroma showing conidiomata. e Peridium. f Ostioles. g-i Conidiogenous cells with attached conidia. j Mature conidia. $\mathrm{k}$ Germinating spore. 1 , m Colonies on MEA (l-from above, mfrom below). Scale bars: $\mathrm{a}=2000 \mu \mathrm{m}, \mathrm{b}=1000 \mu \mathrm{m}, \mathrm{c}, \mathrm{d}=500 \mu \mathrm{m}, \mathrm{f}=200 \mu \mathrm{m}, \mathrm{e}, \mathrm{k}=50$ $\mu \mathrm{m}, \mathrm{g}-\mathrm{j}=10 \mu \mathrm{m}$.

Notes - Morphologically, Cytospora erumpens is most similar to C. sorbi (MFLUCC $16-0631$ ) with conidia $6.4 \times 1.5 \mu \mathrm{m}$ versus $6.5 \times 1.5 \mu \mathrm{m}$. However, in the combined gene phylogenetic analysis, C. erumpens is clearly separated from C. sorbi (Fig. 2). Cytospora 
erumpens and $C$. rusanovii are similar in morphology and also associated with the same host, Salix spp. However, $C$. erumpens differs from $C$. rusanovii in forming black-discoid conidiomata on the host and longer ostiolar necks (C. erumpens: $280-350 \mu \mathrm{m}$ versus $155-$ $170 \mu \mathrm{m}:$ C. rusanovii).
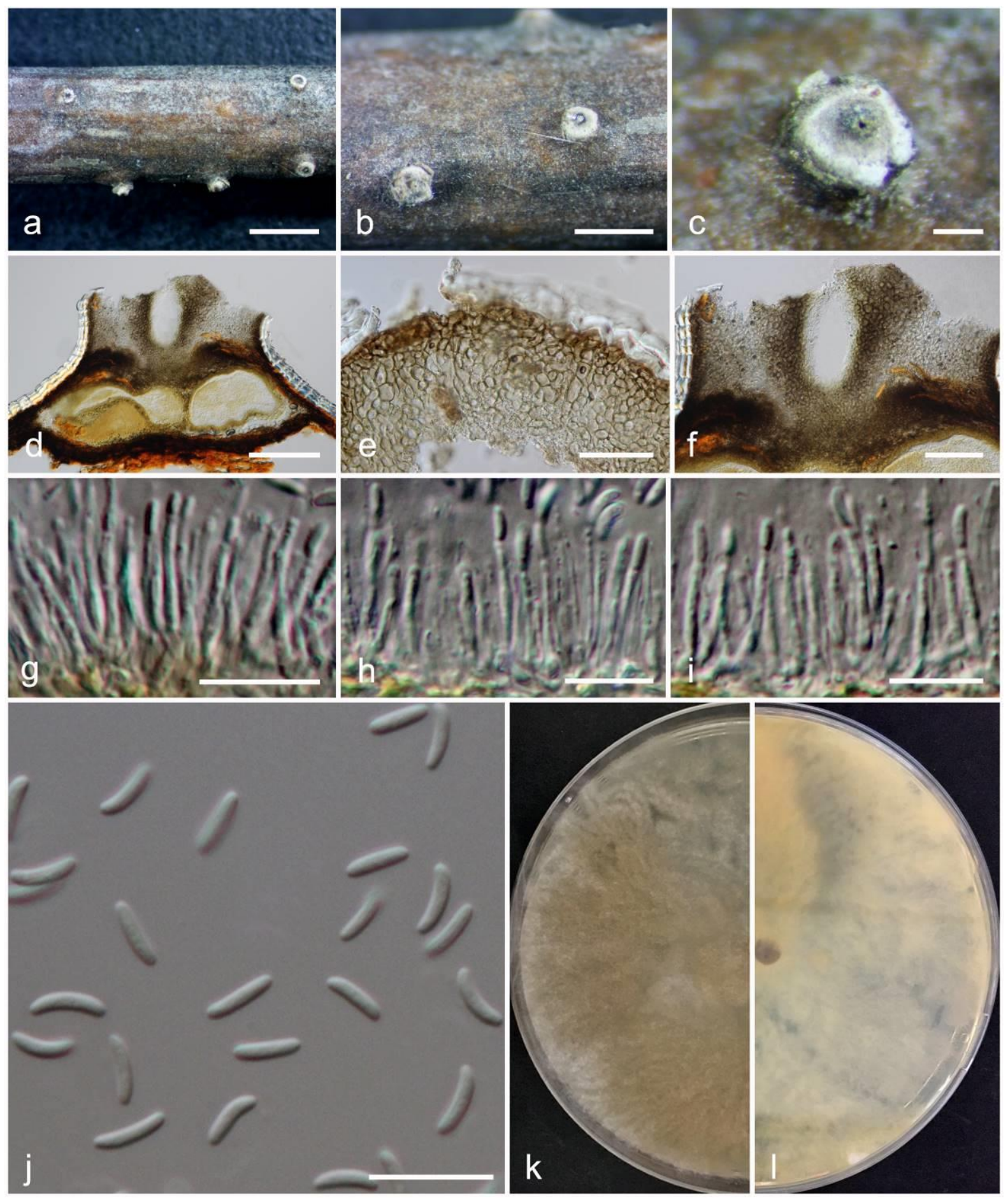

Fig. 6 - Cytospora erumpens on Salix $\times$ fragilis L. (MFLU 15-2165, holotype). a Stromatal habit in wood. b Fruiting bodies on substrate. c Surface of fruiting bodies. d Cross section of the stroma showing conidiomata. e Peridium. f Ostiolar neck. g-i Conidiogenous cells with attached conidia. $\mathrm{j}$ Mature conidia. $\mathrm{k}, 1$ Colonies on MEA ( $\mathrm{k}$-from above, l-from below). Scale bars: $\mathrm{a}=2000 \mu \mathrm{m}, \mathrm{b}=1000 \mu \mathrm{m}, \mathrm{c}, \mathrm{d}=200 \mu \mathrm{m}, \mathrm{e}=50 \mu \mathrm{m}, \mathrm{f}=100 \mu \mathrm{m}, \mathrm{g}-\mathrm{j}=10 \mu \mathrm{m}$. 
In phylogenetic study based on the ITS gene show that Cytospora erumpens is close to $C$. donetzica, but in the combined gene phylogenetic analysis, $C$. erumpens is separated from $C$. donetzica and some species in the genus (C. donetzica, C. sorbicola, C. sorbi, $C$. gigaspora, $C$. nivea, $C$. paratranslucens, $C$. translucens) with Bayesian posterior probabilities of 0.98 (Fig. 2). The ITS, RPB2 and ACT polymorphic nucleotides of sequence data, $C$. erumpens differs from $C$. sorbi with four ITS polymorphisms, 43 RPB2 polymorphisms and 13 ACT polymorphisms. Thus, it is considered that C. erumpens is a novel species.

Cytospora longiostiolata Norphanphoun, Bulgakov, T.C. Wen \& K.D. Hyde, sp. nov. Index Fungorum number: IF552605, Facesoffungi Number: FoF $02740 \quad$ Fig. 7 conidiomata.

Etymology: The specific epithet 'longiostiolata' refers to the long ostiolate of

Holotype: MFLU 15-3784

Associated with twigs and branches of Salix $\times$ fragilis L. [S. alba L. $\times$ S. euxina I.V. Belyaeva]. Sexual morph: Undetermined. Asexual morph: Conidiomata 880-1000 × 480-600 $\mu \mathrm{m}$ diameter, semi-immersed in host tissue, solitary, erumpent, discoid, circular to ovoid, unilocular, with long ostiolar neck with ratio of conidiomata (3:4). Ostioles $400-500 \mu \mathrm{m}$ diameter, at the same level as the disc surface. Peridium comprising several layers of cells of textura angularis, with inner most layer thin, pale brown, outer layer brown. Conidiophores unbranched or occasionally branched at the base, reduced to conidiogenous cells. Conidiogenous cells blastic, enteroblastic, phialidic, formed from the inner most layer of pycnidial wall, hyaline, smooth-walled. Conidia (3.9-)5.4-6.6 $\times 1.0-1.2(-1.5) \mu \mathrm{m}(\overline{\mathrm{x}}=5.5 \times$ $1.3 \mu \mathrm{m}, \mathrm{n}=30$ ), unicellular, allantoid to subcylindrical, hyaline, smooth-walled.

Culture characteristics - Colonies on MEA, reaching $9 \mathrm{~cm}$ diameter after 7 days at 25 ${ }^{\circ} \mathrm{C}$, producing dense mycelium, circular, margin rough, white, with aerial mycelium.

Material examined - RUSSIA, Rostov Region, Krasnosulinsky District, Donskoye forestry, spinney ravine, on dying twigs and branches of Salix $\times$ fragilis L. $[S$. alba L. $\times$ S. euxina I.V. Belyaeva] (Salicaceae), 27 October 2015, T. Bulgakov, T-1122 (MFLU 15-3784, holotype, KUN, isotype), ex-type living culture, MFLUCC 16-0628, KUMCC.

Notes - Cytospora longiostiolata is introduced as new species base on morphological characters and phylogenetic analyses. It has unilocular conidiomata with long ostioles. Phylogenetic analysis using ITS sequence data showed that $C$. longiostiolata is closely related to C. salicina (MFLUCC 15-0862, MFLUCC 16-0637) and C. chrysosperma species (Fig. 1). However, C. salicina $(4.8 \times 1.1 \mu \mathrm{m})$ and $C$. chrysosperma $(4.6 \times 1.2 \mu \mathrm{m})$ differ from C. longiostiolata $(5.5 \times 1.3 \mu \mathrm{m})$ in having multiloculate conidiomata with smaller conidia. In the phylogenetic analyses based on combined ITS, LSU, RPB2 and ACT sequence data, $C$. longiostiolata forms a single lineage, separate from these taxa with high bootstrap support (93\% ML/ 1.00 PP) (Fig. 2).

Cytospora longiostiolata was collected from Salix and is most similar to C. curvata and the differences are discussed under the species $C$. curvata. The species also resembles $C$. donetzica in conidia size $(C$. longiostiolata: $5.5 \times 1.3$ versus $5.5 \times 1.4 \mu \mathrm{m}$ : $C$. donetzica). However, $C$. donetzica differs $C$. longiostiolata in having 3-4 locules conidiomata and shorter ostiolar necks $(150-250 \mu \mathrm{m})$.

In ITS, Cytospora longiostiolata differs from $C$. chrysosperma with two polymorphisms, with $C$. salicina in five polymorphisms. In RPB2 it differs with 21 polymorphisms from $C$. chrysosperma, 19 polymorphisms from $C$. salicina. In ACT it differed in 11 polymorphisms from $C$. chrysosperma and 11 polymorphisms from $C$. salicina. 
Cytospora melnikii Norphanphoun, Bulgakov, T.C. Wen \& K.D. Hyde, sp. nov.

Index Fungorum number: IF552606, Facesoffungi Number: FoF 02741

Fig. 8

Etymology: The species named after the famous Russian mycologist Vadim Alexandrovich Melnik, researcher of anamorphic fungi.

Holotype: MFLU 15-1910

Associated with twigs and branches of Malus domestica Borkh. and Populus nigra L. var. italica Münchh. Sexual morph: Undetermined. Asexual morph: Conidiomata 470-520 × 370-420 $\mu \mathrm{m}$ diameter, semi-immersed in host tissue, solitary, scattered, erumpent, discoid, circular to ovoid, unilocular, with long ostiolar neck. Ostioles 200-230 $\mu \mathrm{m}$ long at the same

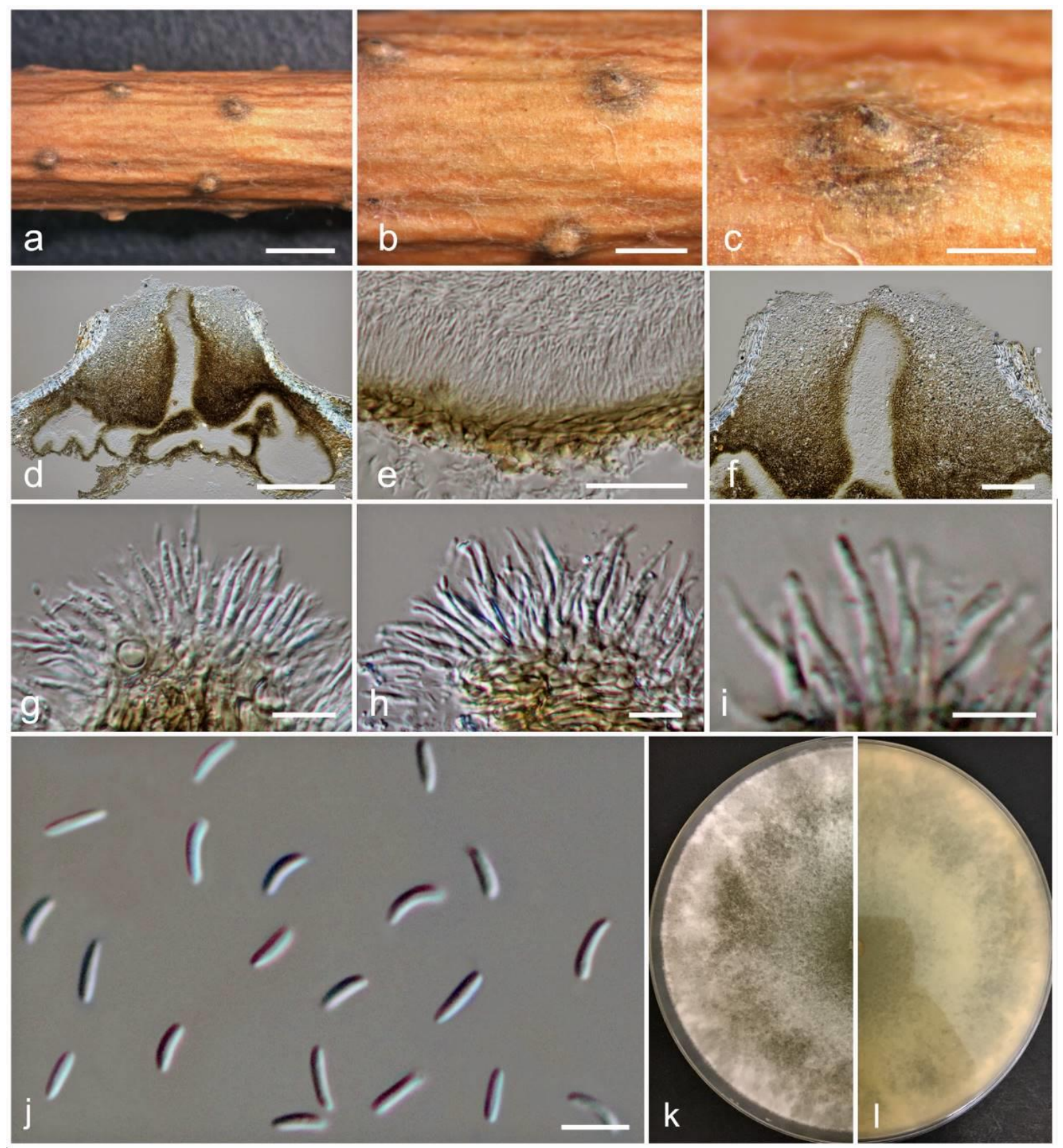

Fig. 7 - Cytospora longiostiolata on Salix $\times$ fragilis (MFLU 15-3784, holotype). a Stromatal habit in wood. b Fruiting bodies on substrate. c Surface of fruiting bodies. d Cross section of the stroma showing conidiomata. e Peridium. f Ostiolar neck. $\mathrm{g}-\mathrm{i}$ Conidiogenous cells with attached conidia. j Mature conidia. k, 1 Colonies on MEA (k-from above, l-from below). Scale bars: $\mathrm{a}=2000 \mu \mathrm{m}, \mathrm{b}=1000 \mu \mathrm{m}, \mathrm{c}=500 \mu \mathrm{m}, \mathrm{d}=200 \mu \mathrm{m}, \mathrm{e}=20 \mu \mathrm{m}, \mathrm{f}=100 \mu \mathrm{m}, \mathrm{g}, \mathrm{h}$ $=10 \mu \mathrm{m}, \mathrm{i}, \mathrm{j}=5 \mu \mathrm{m}$. 
level as the disc surface. Peridium comprising several layers of cells of textura angularis, with inner most layer thick, dark brown, outer layer dark brown to black. Conidiophores unbranched or occasionally branched at the base, reduced to conidiogenous cells. Conidiogenous cells blastic, enteroblastic, phialidic, formed from the inner most layer of pycnidial wall, hyaline, smooth-walled. Conidia (3.1-)4.5-5 ×1-1.2(-1.3) $\mu \mathrm{m}(\overline{\mathrm{x}}=4.6 \times 1.2$ $\mu \mathrm{m}, \mathrm{n}=30)$, unicellular, allantoid to subcylindrical, hyaline, smooth-walled.

Culture characteristics - Colonies on MEA, reaching the edge of the Petri-dish after 6-7 days at $25{ }^{\circ} \mathrm{C}$, producing dense mycelium, circular, margin rough, white, with aerial mycelium.

Material examined - RUSSIA, Rostov Region, Oktyabrsky District, south edge of Persianovsky settlement, Khoruli gully, field-protecting shelterbelt, on dying branches of Malus domestica (Rosaceae), 28 April 2015, T. Bulgakov, T-206 (MFLU 15-1910, holotype, KUN, isotype), ex-type living culture, MFLUCC 15-0851, KUMCC; RUSSIA, Rostov Region, Krasnosulinsky District, Donskoye forestry, lining-out nursery, trees and shrubs, on dying twigs and branches of Populus nigra L. var. italica (Salicaceae), 27 October 2015, T. Bulgakov, T-1104 (MFLU 15-3766, KUN), living culture, MFLUCC 16-0635, KUMCC.

Notes - Cytospora melnikii was found on Malus domestica and Populus nigra, and has semi-immersed, unilocular conidiomata, with long ostioles and shares common walls with the host tissue. Cytospora melnikii can be distinguished based on the characteristics of fruiting bodies, conidia size, cultural characteristics and phylogenetic analyses. Cytospora melnikii is most similar to $C$. chrysosperma, which was found Malus. However, $C$. chrysosperma differs in having a multiloculate conidiomata (Mehrabi et al. 2011).

In phylogenetic analyses, using ITS sequence data (Fig. 1), $C$. melnikii groups with $C$. chrysosperma (HMBF151, HMBF158, HMBF17) and C. salicacearum (MFLUCC 16-0509, MFLUCC 16-0587, MFLUCC 15-0861, MFLUCC 16-0576). The tree using ITS, LSU, RPB2 and ACT sequence data demonstrate that $C$. melnikii is clearly separated from these taxa, with moderate bootstrap support (Fig. 2). Thus, based on phylogenetic analysis and morphological differences, it is considered that $C$. melnikii is a novel species.

Cytospora nivea (Hoffm.) Sacc., Michelia 2: 264 (1881)

For other possible synonyms see Index Fungorum

Facesoffungi Number: FoF 02742

Fig. 9

Associated with twigs and branches of Salix acutifolia Willd. Sexual morph: Undetermined. Asexual morph: Conidiomata 1000-1300 × 340-380 $\mu \mathrm{m}$ diameter, semiimmersed in host tissue, scattered, erumpent, discoid, circular, with 3-4 locules, ostiolate. Ostioles 100-150 $\mu \mathrm{m}$ diameter, at the same level, with flattened top. Peridium comprising a few to several layers of cells of textura angularis, inner layer thick, brown, outer later dark brown. Conidiophores unbranched, reduced to conidiogenous cells. Conidiogenous cells blastic, enteroblastic, phialidic, formed from the inner most layer of pycnidial wall, hyaline, smooth-walled. Conidia (7.1-)7.4-8.8 $\times 1.5-1.6(-1.9) \mu \mathrm{m}(\overline{\mathrm{x}}=7.5 \times 1.8 \mu \mathrm{m}, \mathrm{n}=30)$, unicellular, allantoid, slightly curved ends, hyaline, smooth-walled.

Culture characteristics - Colonies on MEA, reaching $2 \mathrm{~cm}$ diameter, after 7 days at 25 ${ }^{\circ} \mathrm{C}$, producing dense mycelium, circular, margin rough, white, lacking aerial mycelium.

Material examined - RUSSIA, Rostov Region, Ust'-Donestsky District, near Nizhnekundryuchenskaya Village, arenal sandy forest, on dead and dying branches of Salix acutifolia (Salicaceae), 17 August 2015, T. Bulgakov, T-506 (MFLU 15-2210, PDD), living culture, MFLUCC 15-0860, KUMCC.

Notes - Fan et al. (2015b) have reported and illustrated Cytospora nivea (CFCC 89642). The morphology of our fresh collection resembles $C$. nivea (epitype) in Fan et al. (2015b) in having multiloculate conidiomata, allantoid, slightly curved, hyaline and $7.6 \times 1.9$ 
$\mu \mathrm{m}$ conidia and in the combined multi-gene phylogeny (Figs. 1 and 2). This is the first report of $C$. nivea from Salix acutifolia in Russia therefore, details are provided for this species to facilitate identification.
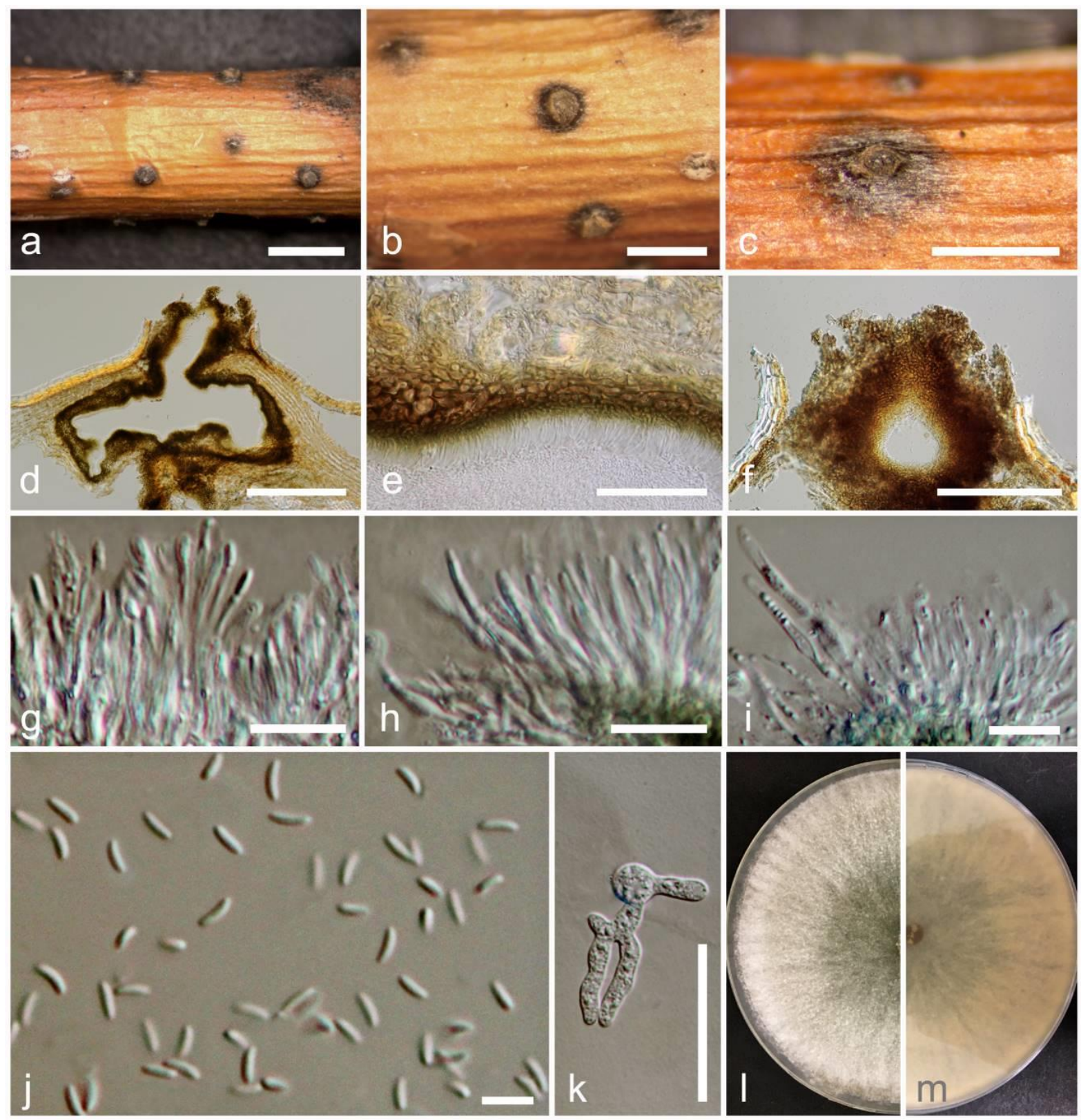

Fig. 8 - Cytospora melnikii on Malus domestica (MFLU 15-1910, holotype). a Stromatal habit in wood. b Fruiting bodies on substrate. c Surface of fruiting bodies. d Cross section of the stroma showing conidiomata. e Peridium. f Ostiolar neck. g-i Conidiogenous cells with attached conidia. j Conidia. $\mathrm{k}$ Germinating spore. $1, \mathrm{~m}$ Colonies on MEA with 7 days (l-from above, $\mathrm{m}$-from below). Scale bars: $\mathrm{a}=2000 \mu \mathrm{m}, \mathrm{b}=500 \mu \mathrm{m}, \mathrm{c}=500 \mu \mathrm{m}, \mathrm{d}=200 \mu \mathrm{m}, \mathrm{e}=30$ $\mu \mathrm{m}, \mathrm{f}=100 \mu \mathrm{m}, \mathrm{g}, \mathrm{h}, \mathrm{i}, \mathrm{j}=10 \mu \mathrm{m}$.

Cytospora parakantschavelii Norphanphoun, Bulgakov, T.C. Wen \& K.D. Hyde, sp. nov. Index Fungorum number: IF552607, Facesoffungi Number: FoF $02743 \quad$ Fig. 10 Etymology: The specific epithet is composed from Greek prefix 'para-' meaning 'near' or 'beside' and 'kantschavelii' is from the species name, in reference to the occurrence on Cytospora species. 
Holotype: MFLU 15-2094

Associated with twigs and branches of Populus $\times$ sibirica G.V. Krylov \& G.V. Grig. ex A.K. Skvortsov [P. balsamifera L. $\times$ P. nigra L.] and Pyrus pyraster (L.) Burgsd.
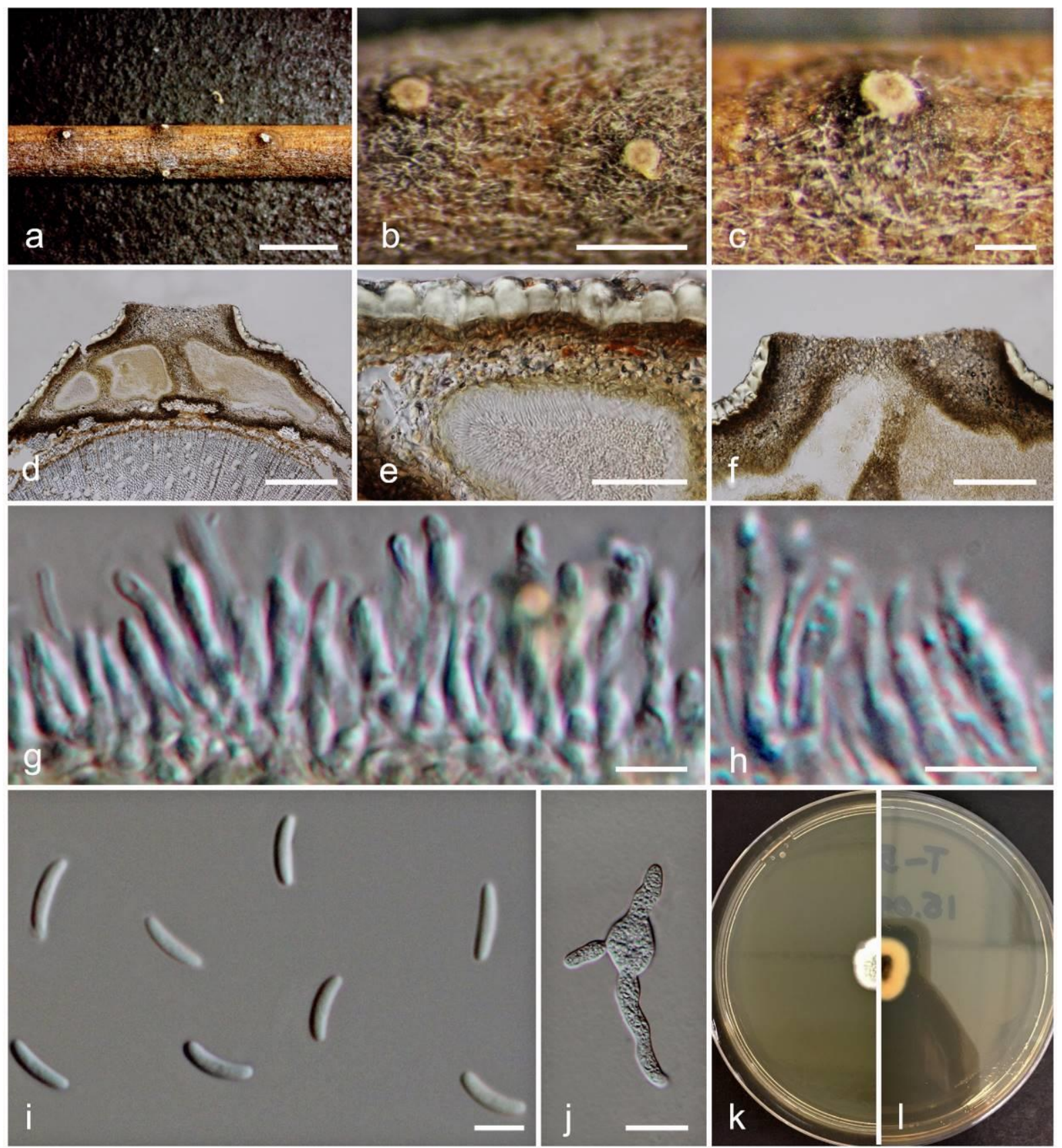

Fig. 9 - Cytospora nivea on Salix acutifolia (MFLU 15-2210). a Stromatal habit in wood. b Fruiting bodies on substrate. c Surface of fruiting bodies. d Cross section of the stroma showing perithecia. e Peridium. f Ostioles. g-h Conidiogenous cells with intact conidia. i Conidia. j Germinating spore. k, 1 Colonies on MEA (k-from above, l-from below). Scale bars: $\mathrm{a}=2000 \mu \mathrm{m}, \mathrm{b}=500 \mu \mathrm{m}, \mathrm{c}, \mathrm{d}=200 \mu \mathrm{m}, \mathrm{e}, \mathrm{f}=50 \mu \mathrm{m}, \mathrm{j}=20 \mu \mathrm{m}, \mathrm{g}, \mathrm{h}, \mathrm{i}=5 \mu \mathrm{m}$.

Sexual morph: Undetermined. Asexual morph: Conidiomata 750-900 × 750-850 $\mu \mathrm{m}$ diameter, semi-immersed in host tissue, solitary, scattered, erumpent, with 3-6 locules, with ostiolar neck. Ostioles 540-680 $\mu \mathrm{m}$ diameter, at the same level as the disc surface. Peridium comprising several layers of cells of textura angularis, with inner most layer thin, hyaline to brown, outer layer brown to dark brown. Conidiophores branched, reduced to conidiogenous 
cells. Conidiogenous cells blastic, enteroblastic, phialidic, hyaline, smooth-walled. Conidia (4.5-)5.3-5.7 $\times 1.1-1.3(-1.6) \mu \mathrm{m}(\overline{\mathrm{x}}=5.3 \times 1.4 \mu \mathrm{m}, \mathrm{n}=30)$, unicellular, elongate-allantoid, hyaline, smooth-walled.

Culture characteristics - Colonies on MEA, reaching $8 \mathrm{~cm}$ diameter after 7 days at 25 ${ }^{\circ} \mathrm{C}$, producing dense mycelium, margin rough, white, lacking aerial mycelium.

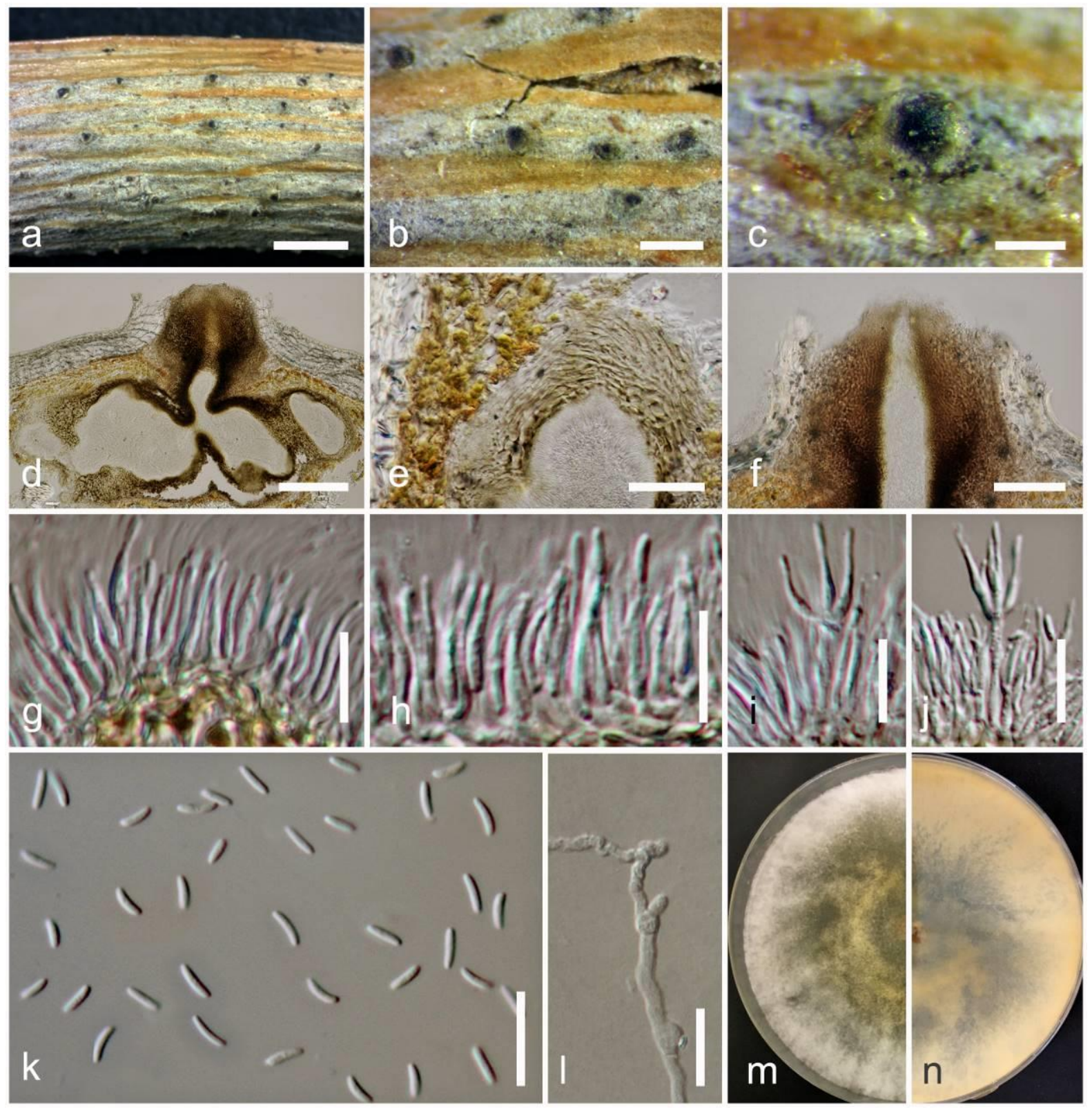

Fig. 10 - Cytospora parakantschavelii on Pyrus pyraster (L.) Burgsd. (MFLU 15-2094, holotype). a Stromatal habit in wood. b Fruiting bodies on substrate. c Surface of fruiting bodies. $d$ Cross section of the stroma showing conidiomata. e Peridium. f Ostiolar neck. $\mathrm{g}-\mathrm{j}$ Conidiogenous cells with attached conidia. $\mathrm{k}$ Mature conidia. 1 Germinating spore. $\mathrm{m}, \mathrm{n}$ Colonies on MEA (m-from above, $n$-from below). Scale bars: $a=2000 \mu \mathrm{m}, \mathrm{b}=500 \mu \mathrm{m}, \mathrm{c}, \mathrm{d}$ $=200 \mu \mathrm{m}, \mathrm{f}=100 \mu \mathrm{m}, \mathrm{e}=50 \mu \mathrm{m}, \mathrm{l}=20 \mu \mathrm{m}, \mathrm{g}-\mathrm{k}=10 \mu \mathrm{m}$. 

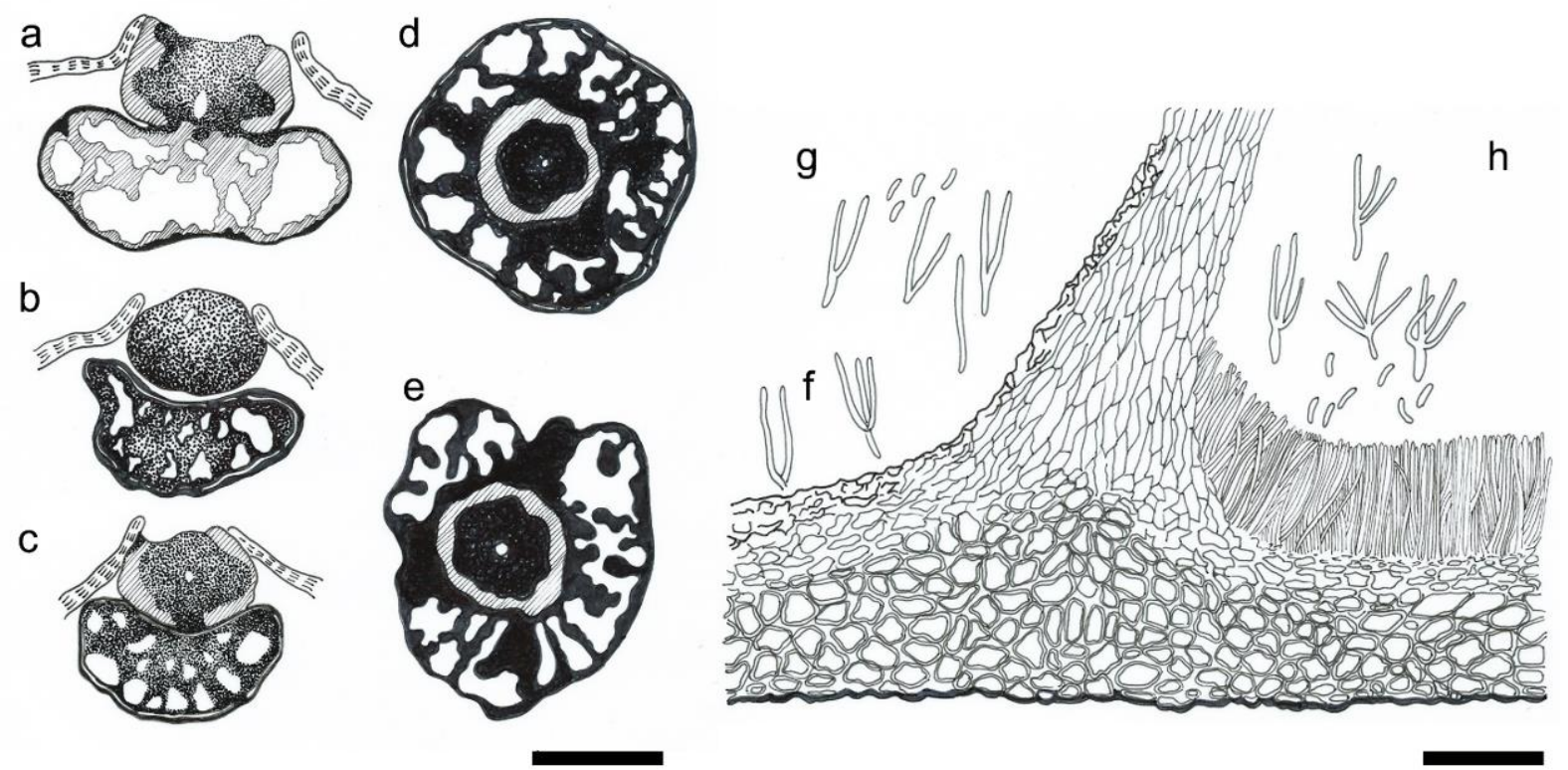

Fig. 11 - Cytospora kantschavelii on Populus nigra L. (Redrawn from Gvritishvili 1973), URSS (LE) holotype). a-c Stromata showing conidiomata. d, e Transverse sections through conidiomata. f, g Conidiophores and Conidiogenous cells with attached conidia. $\mathrm{h}$ Stroma showing peridium and conidiophores. Scale bars: a, b, c, d, e $=500 \mu \mathrm{m}, \mathrm{g}, \mathrm{h}=20 \mu \mathrm{m}$.

Material examined - RUSSIA, Rostov Region, Shakhty City, steppe slopes near Grushevsky pond, ravine shrubbery, on dead and dying branches of Pyrus pyraster (L.) Burgsd. [= P. communis auct.] (Rosaceae), 14 May 2015, T. Bulgakov (MFLU 15-2094, holotype, PDD isotype), ex-type living culture, MFLUCC 16-0575, KUMCC; RUSSIA, Rostov Region, Shakhty City, block landpark, on dying branches of Populus $\times$ sibirica G.V. Krylov \& G.V. Grig. ex A.K. Skvortsov [P. balsamifera L. $\times$ P. nigra L.] (Salicaceae), 12 May 2015, T. Bulgakov (MFLU 15-1953, PDD), living culture, MFLUCC 15-0857, KUMCC.

Notes - The new species, Cytospora parakantschavelii (MFLUCC 16-0575, MFLUCC 15-0857) is similar to $C$. kantschavelii (287-2) in having multiloculate conidiomata. However, conidial dimensions of $C$. parakantschavelii $(5.3 \times 1.4 \mu \mathrm{m})$ are longer and wider than those of $C$. kantschavelii $(4-5 \times 1.2 \mu \mathrm{m})$ (Fig. 11) (Gvritishvili 1973).

Phylogenetic analysis of four combined gene loci place Cytospora parakantschavelii (MFLUCC 16-0575, MFLUCC 15-0857) on a separate branch from C. kantschavelii, forming as a sister taxon to C. salicicola Norphanphoun, Bulgakov \& Hyde (MFLUCC 14-1052, MFLUCC 15-0866) (Fig. 2). However, C. salicicola differs from C. parakantschavelii in having shorter ostioles $(170-200 \mu \mathrm{m})$, unbranched conidiophores and larger conidia $(6.8 \times$ $1.6 \mu \mathrm{m})$.

Cytospora parasitica Norphanphoun, Bulgakov, T.C. Wen \& K.D. Hyde, in Ariyawansa et al., Fungal Diversity: 75(1): 146 (2015)

Facesoffungi Number: FoF 02744

Fig. 12

Associated with twigs and branches of Malus domestica Borkh. Sexual morph: Undetermined. Asexual morph: Conidiomata 1700-2000 × 900-1200 $\mu \mathrm{m}$ diameter, semiimmersed in host tissue, scattered, erumpent, multi-loculate, with ostiolar neck. Ostioles 320$400 \mu \mathrm{m}$ diameter, at same level as the disc surface. Peridium comprising a few to several layers of cells of textura angularis, with most layer thin, brown to dark brown. Conidiophores unbranched or occasionally branched at the base, reduced to conidiogenous 
cells. Conidiogenous cells blastic, enteroblastic, phialidic, formed from the inner most layer of pycnidial wall, hyaline, smooth-walled. Conidia $(5.5-) 6.9-7.3 \times 1.5-1.7(-2) \mu \mathrm{m}(\overline{\mathrm{x}}=6.8 \times$ $1.8 \mu \mathrm{m}, \mathrm{n}=30$ ), unicellular, elongate-allantoid, hyaline, smooth-walled.

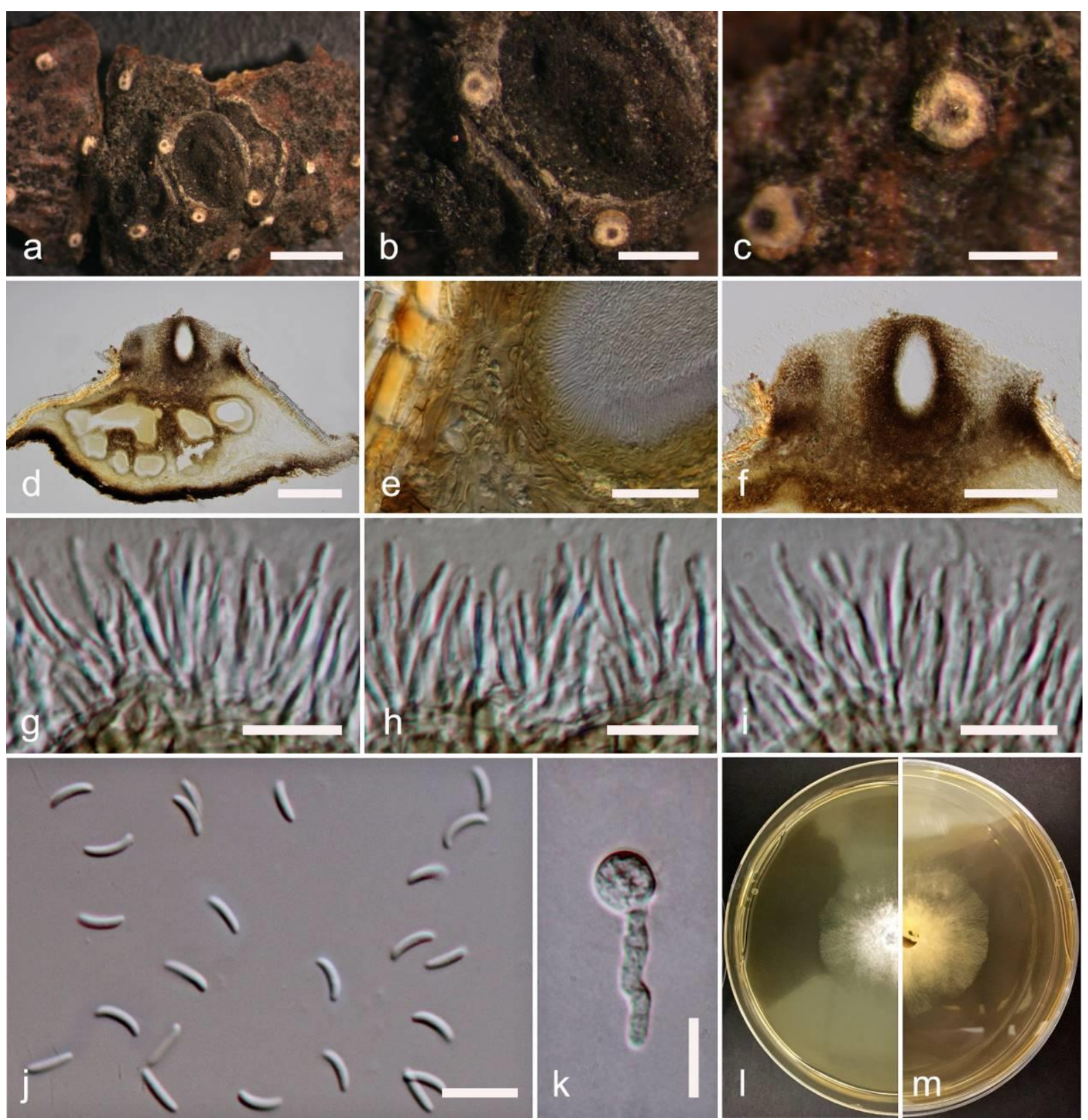

Fig. 12 - Cytospora parasitica on Malus domestica Borkh (MFLU 15-1991). a Stromatal habit in wood. b Fruiting bodies on substrate. c Surface of fruiting bodies. d Cross section of the stroma showing conidiomata. e Peridium. f Ostiolar neck. g-i Conidiogenous cells with attached conidia. j Mature conidia. $\mathrm{k}$ Germinating spore. 1, m Colonies on MEA (1-from above, $\mathrm{m}$-from below). Scale bars: $\mathrm{a}=2000 \mu \mathrm{m}, \mathrm{b}=1000 \mu \mathrm{m}, \mathrm{c}=500 \mu \mathrm{m}, \mathrm{d}=300 \mu \mathrm{m}, \mathrm{e}=$ $30 \mu \mathrm{m}, \mathrm{f}=200 \mu \mathrm{m}, \mathrm{g}, \mathrm{h}, \mathrm{i}, \mathrm{j}, \mathrm{k}=10 \mu \mathrm{m}$.

Culture characteristics - Colonies on MEA, reaching $4 \mathrm{~cm}$ diameter, after 7 days at 25 ${ }^{\circ} \mathrm{C}$, producing dense mycelium, circular, margin rough, white, lacking aerial mycelium.

Material examined - RUSSIA, Rostov Region, Shakhty City, Grushevka steppe slopes near Grushevsky pond, ravine shrubbery, on dying branches (necrotrophic) of Malus 
domestica (Rosaceae), 14 May 2015, T. Bulgakov (MFLU 15-1991, PDD), living culture, MFLUCC 16-0507, KUMCC.

Notes - Cytospora parasitica Norphanphoun, Bulgakov \& K.D. Hyde was introduced by Ariyawansa et al. (2015) from Malus domestica in Russia (Ariyawansa et al. 2015). The morphology of this collection (MFLUCC 16-0507) is similar to C. parasitica (MFLUCC 141055) in having multi-loculate conidiomata and allantoid to slightly curved, unicellular, hyaline, $7 \times 1.75 \mu \mathrm{m}$ conidia (Ariyawansa et al. 2015). In phylogenetic analyses, $C$. parasitica (MFLUCC 16-0507) groups with the ex-type strain (MFLUCC 14-1055) of $C$. parasitica (Fig. 2).

Cytospora paratranslucens Norphanphoun, Bulgakov, T.C. Wen \& K.D. Hyde, sp. nov. Index Fungorum number: IF552608, Facesoffungi Number: FoF 02745

Fig. 13

Etymology: The specific epithet is composed from Greek prefix 'para-' meaning 'near' or 'beside' and Latin 'translucens' is from the species name, in reference to the occurrence on Cytospora.

Holotype: MFLU 15-1986

Associated with twigs and branches of Populus alba L. Sexual morph: Undetermined. Asexual morph: Conidiomata 450-550 × 270-350 $\mu \mathrm{m}$ diameter, semi-immersed in host tissue, scattered, erumpent, breaking through the outer branch, multiloculate, with ostiolar neck. Ostioles $70-150 \mu \mathrm{m}$ diameter, at same level as the disc surface. Peridium comprising a few to several layers of cells of textura angularis, with inner most layer thin, red-brown, outer later dark brown to black. Conidiophores unbranched, reduced to conidiogenous cells. Conidiogenous cells blastic, enteroblastic, phialidic, formed from the inner most layer of pycnidial wall, hyaline, smooth-walled. Conidia (5.5-)6.5-7.3 $\times 1.3-1.5(-1.8) \mu \mathrm{m}(\overline{\mathrm{x}}=6.8 \times$ $1.6 \mu \mathrm{m}, \mathrm{n}=30$ ), unicellular, allantoid, slightly curved, hyaline, smooth-walled.

Culture characteristics - Colonies on MEA, reaching $8.5 \mathrm{~cm}$ diameter after 7 days at $25^{\circ} \mathrm{C}$, producing dense mycelium, circular, margin rough, white, with aerial mycelium.

Material examined - RUSSIA, Rostov Region, Shakhty City, Grushevka steppe slopes near Grushevsky pond, riparian grove, on dead and dying branches of Populus alba, 14 May 2015, T. Bulgakov, T-282 (MFLU 15-1986, holotype, PDD, isotype), ex-type living culture, MFLUCC 16-0506, KUMCC; RUSSIA, Rostov Region, Krasnosulinsky District, Donskoye forestry, lining-out nursery, trees and shrubs, dying twigs and branches on Populus alba L. var. bolleana (Lauche) Otto, 27 October 2015, T. Bulgakov, T-1016 (MFLU 153678, PDD), living culture, MFLUCC 16-0627, KUMCC.

Notes - Cytospora species associated with Populus have been reported worldwide (Table 3; Adams et al. 2002, 2005, 2006, Défago 1942, Fotouhifar et al. 2010, Singh et al. 2007). In this study, five novel species are introduced, which were collected from Populus viz. C. melnikii, C. parakantschavelii, $C$. paratranslucens, $C$. rusanovii and $C$. salicacearum. Cytospora paratranslucens is most similar to C. germanica and C. nivea (Adams et al. 2006). However, they can be distinguished by conidia size $(6.8 \times 1.6$ versus $5 \times 1,6-7.5 \times 1.2 \mu \mathrm{m}$ respectively) (Adams et al. 2006). Furthermore, $C$. paratranslucens has multiloculate conidiomata sharing a single ostiole, while $C$. germanica and $C$. nivea have multiloculate conidiomata with individual or compressed ostioles in the conidiostromata.

In the ITS phylogenetic analyses, Cytospora paratranslucens groups with $C$. translucens Sacc. (138-2 and 35) with high bootstrap support (94\% ML/ 1.00 PP). ITS sequence data is only available for $C$. translucens in GenBank. Therefore, we compare morphology of $C$. paratranslucens and $C$. translucens, from the original description in Saccardo (1884). Cytospora paratranslucens can be distinguished from $C$. translucens in having multiloculate conidiomata, while in $C$. translucens they are uniloculate. The conidia 
of $C$. paratranslucens are larger than those of $C$. translucens $(6.8 \times 1.6 \mu$ m versus $4.6 \times 1.2$ $\mu \mathrm{m})$.

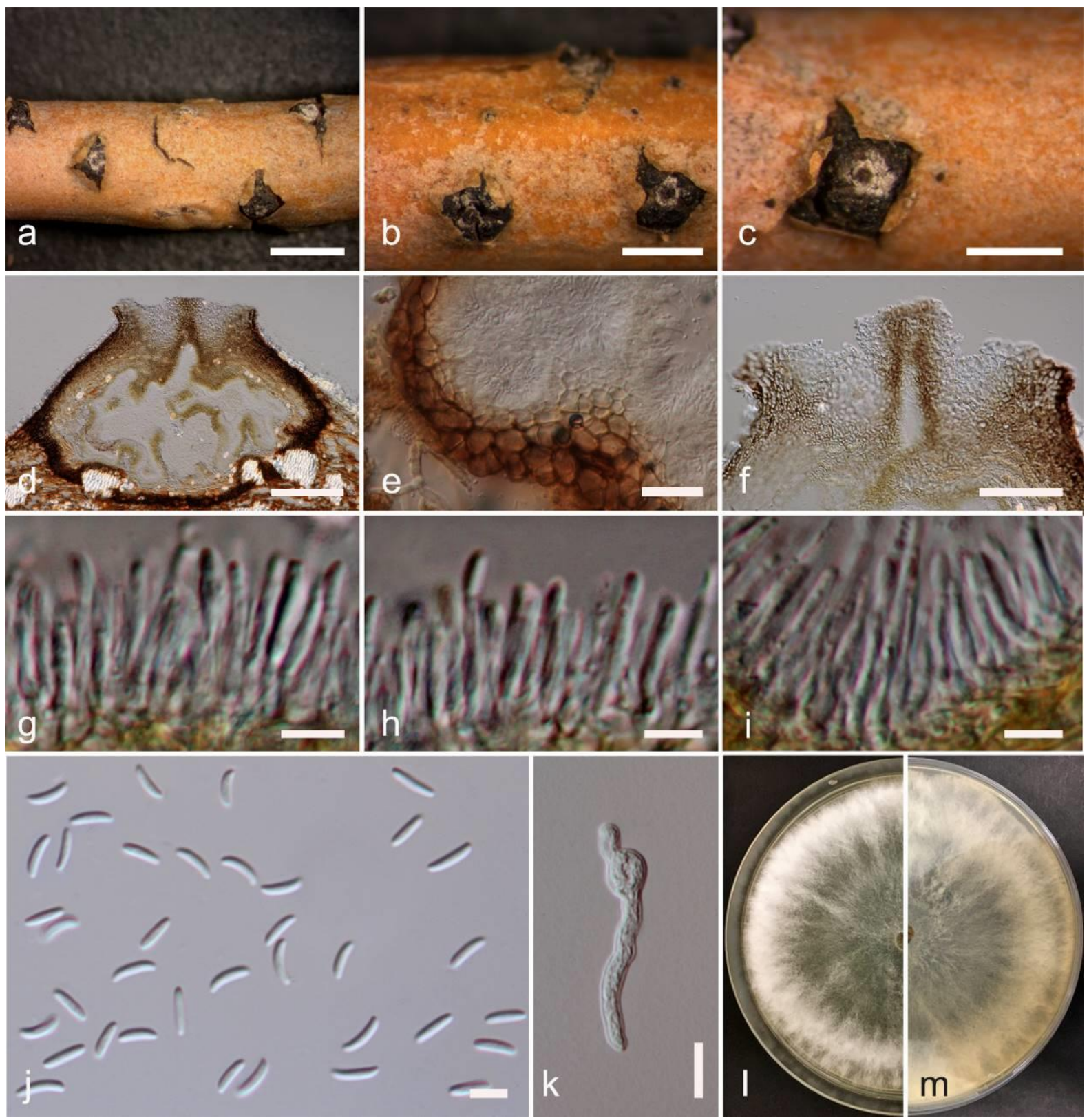

Fig. 13 - Cytospora paratranslucens on Populus alba (MFLU 15-1986, holotype). a Stromatal habit in wood. b Fruiting bodies on substrate. c Surface of fruiting bodies. d Cross section of the stroma showing conidiomata. e Peridium. f Ostiolar neck. g-i Conidiogenous cells with attached conidia. $\mathrm{j}$ Mature conidia. $\mathrm{k}$ Germinating spore. $1, \mathrm{~m}$ Colonies on MEA (1from above, $\mathrm{m}$-from below). Scale bars: $\mathrm{a}=2000 \mu \mathrm{m}, \mathrm{b}=1000 \mu \mathrm{m}, \mathrm{c}=1000 \mu \mathrm{m}, \mathrm{d}=200$ $\mu \mathrm{m}, \mathrm{e}=20 \mu \mathrm{m}, \mathrm{f}=100 \mu \mathrm{m}, \mathrm{g}, \mathrm{h}, \mathrm{i}, \mathrm{j}=5 \mu \mathrm{m}, \mathrm{k}=10 \mu \mathrm{m}$.

Cytospora rusanovii Norphanphoun, Bulgakov, T.C. Wen \& K.D. Hyde, sp. nov. Index Fungorum number: IF552609, Facesoffungi Number: FoF 02746 Fig. 14 Etymology: The specific named after the Russian mycologist Victor Andreyevich Rusanov, researcher of plant pathogenic fungi in Rostov region of Russia.

Holotype: MFLU 15-1931 
Associated with twigs and branches of Salix babylonica L. and Populus $\times$ sibirica G.V. Krylov \& G.V. Grig. ex A.K. Skvortsov [P. balsamifera L. $\times$ P. nigra L.]. Sexual morph: Undetermined. Asexual morph: Conidiomata 530-800 × 280-350 $\mu \mathrm{m}$ diameter, semi-immersed in host tissue, solitary, scattered, erumpent, discoid, circular to ovoid, with 13 locules, and long ostiolar neck. Ostioles 155-170 $\mu$ m diameter, at the same level as the disc surface. Peridium comprising several layers of cells of textura angularis, with inner most layer thick, dark brown, outer layer dark brown to black. Conidiophores unbranched, reduced to conidiogenous cells. Conidiogenous cells blastic, enteroblastic, phialidic, formed from the inner most layer of pycnidial wall, hyaline, smooth-walled. Conidia $(6-) 6.5-7.1 \times 1.4-1.5(-$ 1.6) $\mu \mathrm{m}(\overline{\mathrm{x}}=6.7 \times 1.5 \mu \mathrm{m}, \mathrm{n}=30)$, unicellular, elongate-allantoid, hyaline, smooth-walled.

Culture characteristics - Colonies on MEA, reaching $8 \mathrm{~cm}$ diameter after 7 days at 25 ${ }^{\circ} \mathrm{C}$, producing dense mycelium, circular, margin rough, white, lacking aerial mycelium.

Material examined - RUSSIA, Rostov Region, Shakhty City, Central Park, parkland, on dying branches of Salix babylonica (Salicaceae), 8 July 2015, T. Bulgakov (MFLU 151931, holotype, KUN, isotype), ex-type living culture, MFLUCC 15-0854, KUMCC; RUSSIA, Rostov Region, Shakhty City, Central Park, parkland, on dying branches of Populus $\times$ sibirica G.V. Krylov \& G.V. Grig. ex A.K. Skvortsov [P. balsamifera L. $\times P$. nigra L.] (Salicaceae), 9 July 2015, T. Bulgakov (MFLU 15-1929, KUN), living culture, MFLUCC 15-0853, KUMCC.

Notes - The new species has semi-immersed, 1-3-loculate conidiomata, with long ostioles and $6.7 \times 1.5 \mu \mathrm{m}$, unicellular conidia. Cytospora rusanovii is most similar to $C$. microspora Rabenh. in conidia size (6-7 × 1-1.3) (Saccardo 1884). However, C. microspora differs from $C$. rusanovii in having multi-loculate conidiomata (>10 locules) (Corda 1839).

Phylogenetic analyses of ITS and multi-gene sequence data (Figs. 1 and 2) indicate that Cytospora rusanovii can be distinguished from C. curvata (MFLUCC 15-0865) and other species in Cytospora, with 98\% bootstrap support and 1.00 Bayesian posterior probability in MP, ML and BI analyses (Fig. 2), while the polymorphic nucleotides differences are discussed under C. curvata.

Cytospora salicicola Norphanphoun, Bulgakov, T.C. Wen \& K.D. Hyde, in Li et al., Fungal Diversity 78: 10.1007/s13225-016-0366-9, [78] (2016)

Facesoffungi Number: FoF 02747

Fig. 15

Associated with twigs and branches of Salix alba L. Sexual morph: Undetermined. Asexual morph: Conidiomata 750-1200 × 300-450 $\mu \mathrm{m}$ diameter, semi-immersed in host tissue, solitary, scattered, visible as raised areas, with 3-4 locules and long ostiolar neck. Ostioles 170-200 $\mu \mathrm{m}$ diameter, at the base, same level as the host surface, black to brown, surrounded by a light coloured ostiolar disk. Peridium comprising several layers of cells of textura angularis, with inner most layer thin, hyaline to brown, outer layer brown to dark brown. Conidiophores unbranched, reduced to conidiogenous cells. Conidiogenous cells blastic, enteroblastic, phialidic, formed from the inner most layer of pycnidial wall, hyaline, smooth-walled. Conidia $(6.2-) 6.9-7.6 \times 1.4-1.5(-1.7) \mu \mathrm{m}(\overline{\mathrm{x}}=6.8 \times 1.6 \mu \mathrm{m}, \mathrm{n}=30)$, unicellular, allantoid to subcylindrical, hyaline, smooth-walled.

Culture characteristics - Colonies on MEA, reaching $9 \mathrm{~cm}$ diameter, after 7 days at 25 ${ }^{\circ} \mathrm{C}$, producing dense mycelium, circular, margin rough, white, lacking aerial mycelium.

Material examined - RUSSIA, Rostov Region, Krasnosulinsky District, Donskoye forestry, Gremuchaya Balka (Thunderous gully), shore of pond, on dead and dying branches of Salix alba (Salicaceae), 28 June 2015, T. Bulgakov, T-527 (MFLU 15-2231, KUN), living culture, MFLUCC 15-0866, KUMCC.

Notes - Cytospora salicicola was introduced by Li et al. (2016) from Salix alba in Russia (Hyde et al. 2016, Li et al. 2016). In the phylogenetic analyses, our strain MFLUCC 
15-0866 groups with the type material of C. salicicola (MFLUCC 14-1052) with high bootstrap support from all analyses (99\% MP/ 83\% ML/ 0.99 PP) (Fig. 2).
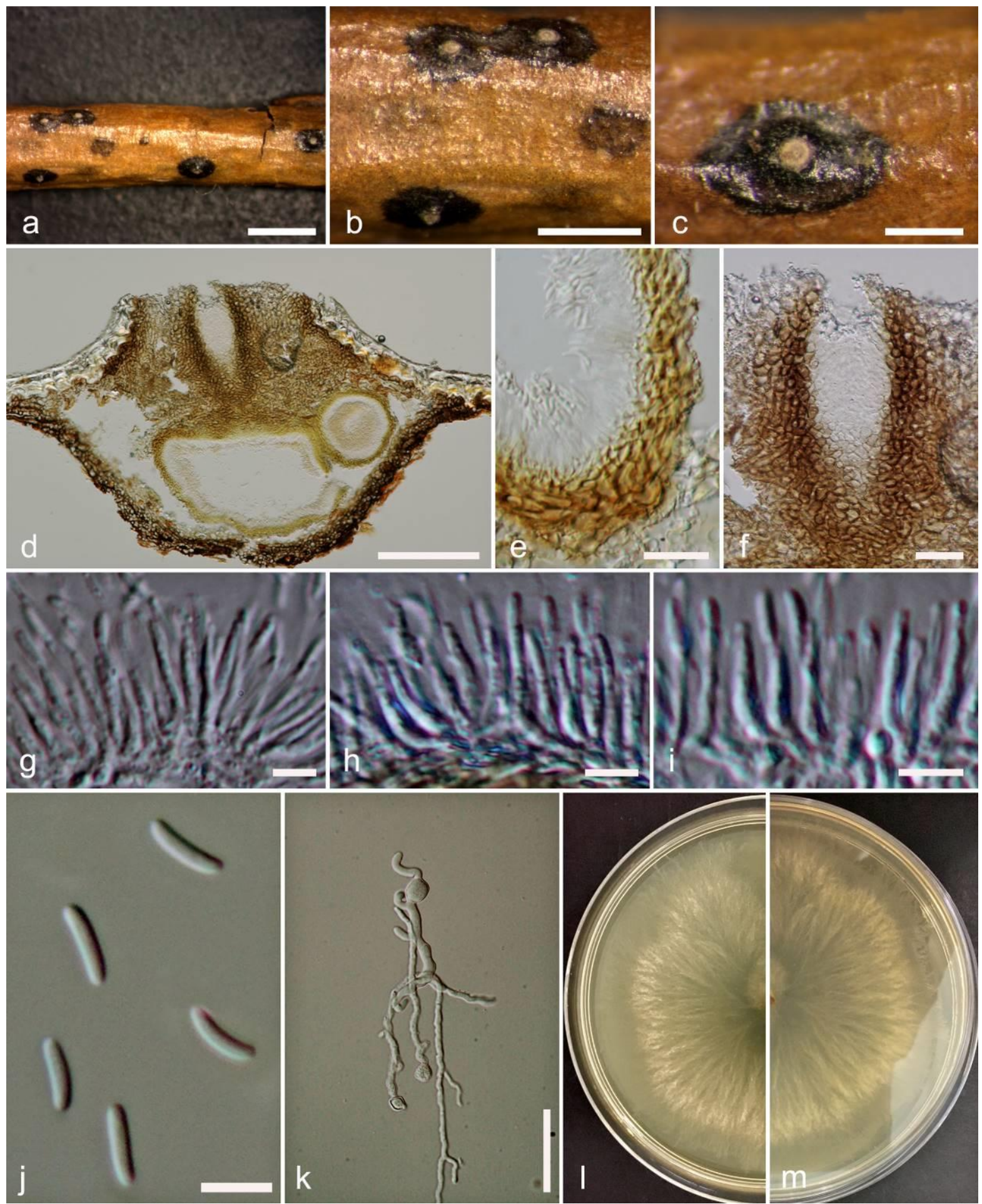

Fig. 14 - Cytospora rusanovii on Salix babylonica (MFLU 15-1931, holotype). a Stromatal habit in wood. b Fruiting bodies on substrate. c Surface of fruiting bodies. d Cross section of the stroma showing conidiomata. e Peridium. f Ostioles. g-i Conidiogenous cells with attached conidia. j Mature conidia. $\mathrm{k}$ Germinating spore. 1, $\mathrm{m}$ Colonies on MEA (1-from above, $\mathrm{m}$-from below). Scale bars: $\mathrm{a}=2000 \mu \mathrm{m}, \mathrm{b}=1000 \mu \mathrm{m}, \mathrm{c}=500 \mu \mathrm{m}, \mathrm{d}=100 \mu \mathrm{m}, \mathrm{e}=$ $10 \mu \mathrm{m}, \mathrm{f}=20 \mu \mathrm{m}, \mathrm{g}, \mathrm{h}, \mathrm{i}, \mathrm{j}=5 \mu \mathrm{m}, \mathrm{k}=50 \mu \mathrm{m}$. 

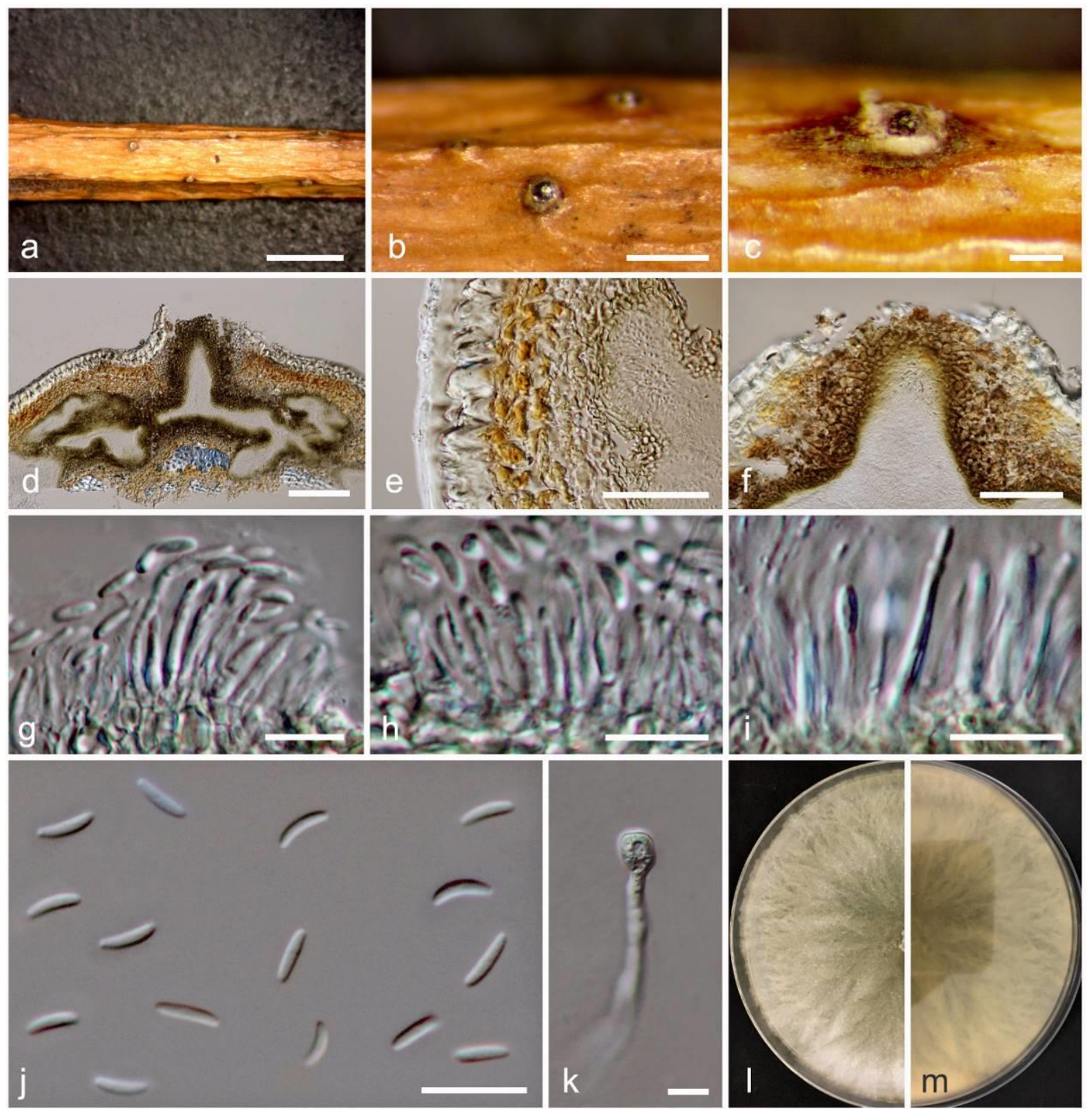

Fig. 15 - Cytospora salicicola on Salix alba (MFLU 15-2231). a Stromatal habit in wood. b Fruiting bodies on host surface. c Surface of fruiting bodies showing the black Ostioles. d Cross section of the stroma showing conidiomata. e Peridium. f Ostiolar neck. $\mathrm{g}-\mathrm{i}$ Conidiogenous cells with intact conidia. j Mature conidia. k Germinating conidia. 1, $\mathrm{m}$ Colonies on MEA (l-from above, $\mathrm{m}$-from below). Scale bars: $\mathrm{a}=2000 \mu \mathrm{m}, \mathrm{b}=500 \mu \mathrm{m}, \mathrm{c}=$ $200 \mu \mathrm{m}, \mathrm{d}=100 \mu \mathrm{m}, \mathrm{e}=50 \mu \mathrm{m}, \mathrm{f}=100 \mu \mathrm{m}, \mathrm{g}-\mathrm{k}=10 \mu \mathrm{m}$.

Cytospora salicacearum Norphanphoun, Bulgakov, T.C. Wen \& K.D. Hyde, sp. nov.

Index Fungorum number: IF552610, Facesoffungi Number: FoF 02748

Fig. 16

Etymology: The specific epithet salicacearum refers to host plant family Salicaceae, on which the fungus was first collected.

Holotype: MFLU 15-2061

Associated with twigs and branches of Salix alba L., Salix $\times$ fragilis L. [S. alba L. $\times$ S. euxina I.V. Belyaeva], Populus nigra L. var. italica Münchh. and Prunus cerasus L. Sexual morph: Undetermined. Asexual morph: Conidiomata 570-750 × 320-380 $\mu \mathrm{m}$ diameter, semi-immersed in host tissue, solitary, scattered, erumpent, discoid, circular to ovoid, with 1-2 locules, ostiolate. Ostioles 160-200 $\mu \mathrm{m}$ diameter, at the same level as the 
disc surface. Peridium comprising a few to several layers of cells of textura angularis, with inner most layer thin, dark brown, outer layer dark brown to black. Conidiophores unbranched or occasionally branched at the base, reduced to conidiogenous cells. Conidiogenous cells blastic, enteroblastic, phialidic, formed from the inner most layer of pycnidial wall, hyaline, smooth-walled. Conidia (3.6-)4.9-6.4 $\times 0.9-1(-1.1) \mu \mathrm{m}(\overline{\mathrm{x}}=5 \times 1$ $\mu \mathrm{m}, \mathrm{n}=30$ ), unicellular, allantoid to subcylindrical, hyaline, smooth-walled.

Culture characteristics - Colonies on MEA, reaching $1.5 \mathrm{~cm}$ diameter after 7 days at $25^{\circ} \mathrm{C}$, producing rhizoid mycelium, undulate, margin rough, white, lacking aerial mycelium.

Material examined - RUSSIA, Rostov Region, Shakhty City, steppe slopes near Grushevsky pond, osier-bed near pond, on dead and dying branches of Salix alba (Salicaceae), 14 May 2015, T. Bulgakov, T-357 (MFLU 15-2061, holotype, KUN, isotype), ex-type living culture, MFLUCC 16-0509, KUMCC; RUSSIA, Rostov Region, Shakhty City, steppe slopes near Grushevsky pond, riparian grove, dead and dying branches on Populus nigra L. var. italica Münchh (Salicaceae), 14 May 2015, T. Bulgakov, T-393 (MFLU 152097, KUN), living culture, MFLUCC 16-0576, KUMCC; RUSSIA, Rostov Region, Krasnosulinsky District, Donskoye forestry, old orchard, dead and dying branches on Prunus cerasus L., 18 June 2015, T. Bulgakov, T-503 (MFLU 15-2207, KUN), living culture, MFLUCC 16-0587, KUMCC; RUSSIA, Rostov Region, Krasnosulinsky District, Donskoye forestry, riparian forest, on dead and dying branches of Salix $\times$ rubens Schrank [S. alba L. $\times$ S. fragilis L.] (Salicaceae), 18 June 2015, T. Bulgakov, T-509 (MFLU 15-2213, KUN), living culture, MFLUCC 15-0861, KUMCC.

Notes - Cytospora salicacearum has 1-2 loculate conidiomata with a single ostioles and shares common walls. In the phylogenetic analyses based on combined ITS, LSU, RPB2 and ACT sequence data, $C$. salicacearum is a close relative to $C$. melnikii (MFLUCC 150851, MFLUCC 16-0635) and C. chrysosperma (HMBF17, HMBF151, HMBF158, HMBF159) (Fig. 2). However, they are different in morphological characteristics, C. melnikii and $C$. chrysosperma differ from $C$. salicacearum in having shorter and wider conidia $(4.6 \times$ $1.2 \mu \mathrm{m}, 4.6 \times 1.2 \mu \mathrm{m}, 5 \times 1 \mu \mathrm{m}$, respectively).

Cytospora salicacearum differs from $C$. melnikii and $C$. chrysosperma in the polymorphic nucleotides of the RPB2 and ACT sequence data. In RPB2 it differed with 35 polymorphisms from $C$. chrysosperma, four polymorphisms from $C$. melnikii. In ACT it differed with eight polymorphisms from $C$. chrysosperma and differs from $C$. melnikii with four polymorphisms.

Cytospora salicina Norphanphoun, Bulgakov, T.C. Wen \& K.D. Hyde, sp. nov.

Index Fungorum number: IF552611, Facesoffungi Number: FoF 02749

Etymology: The specific epithet 'salicina' refers to the host plant genus Salix, on which the type specimens were collected.

Holotype: MFLU 15-2212

Associated with twigs and branches of Salix alba L. and Salix $\times$ rubens Schrank $[S$. alba L. $\times$ S. fragilis L.]. Sexual morph: Undetermined. Asexual morph: Conidiomata 1200$1500 \times 550-600 \mu \mathrm{m}$ diameter, semi-immersed in host tissue, solitary, scattered, erumpent, discoid, circular to ovoid, with 2-5 locules, and ostiolar neck. Ostioles 300-350 $\mu \mathrm{m}$. at the same level as the disc surface. Peridium comprising several layers of cells of textura angularis, with inner most layer thick, dark brown, outer layer dark brown to black. Conidiophores branched or occasionally branched at the base, reduced to conidiogenous cells. Conidiogenous cells blastic, enteroblastic, phialidic, hyaline, smooth-walled. Conidia (3.6-)4.2-4.7 $\times 1-1.1(-1.3) \mu \mathrm{m}(\overline{\mathrm{x}}=4.3 \times 1 \mu \mathrm{m}, \mathrm{n}=30)$, unicellular, allantoid to subcylindrical, hyaline, smooth-walled. 


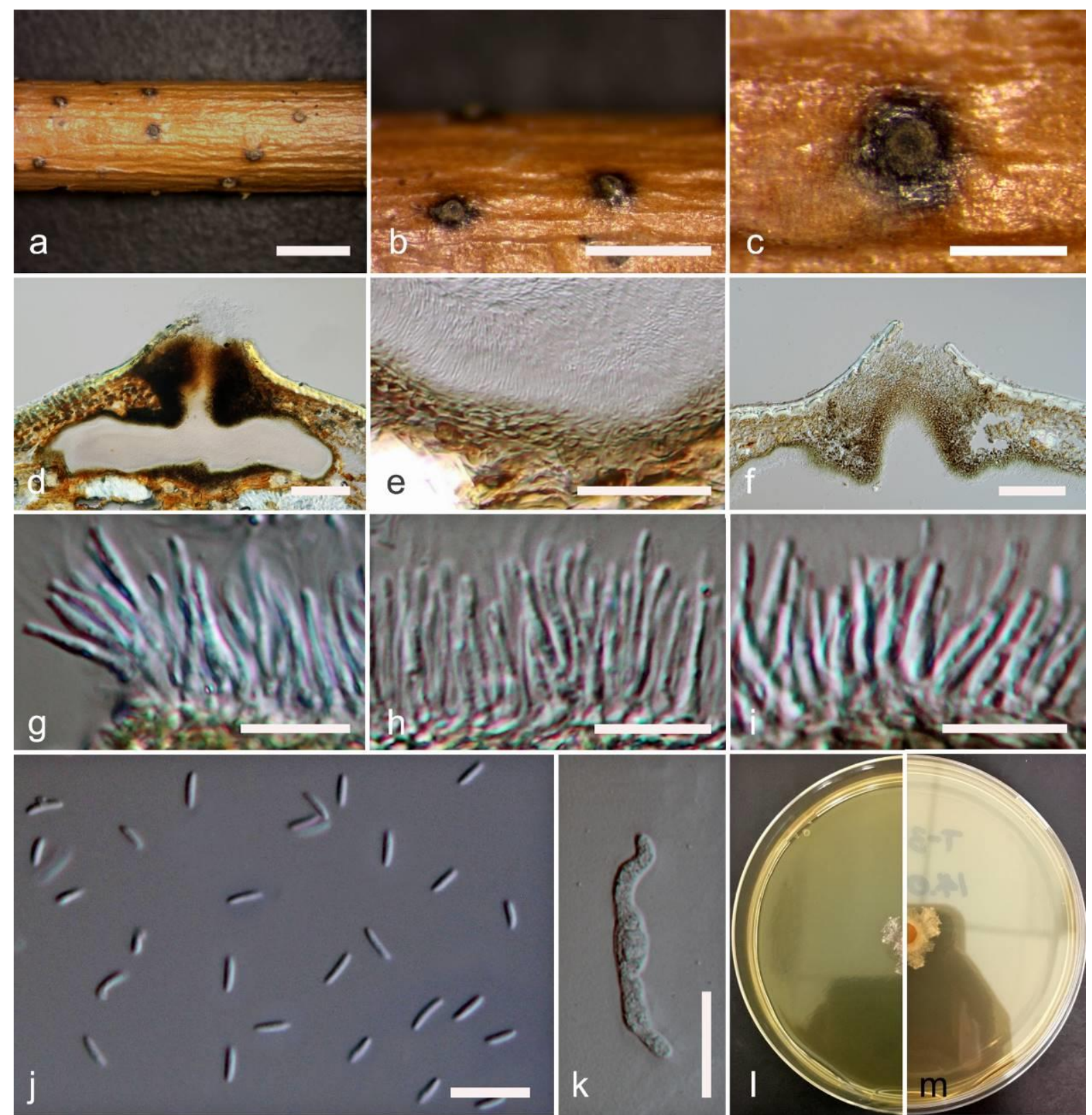

Fig. 16 - Cytospora salicacearum on Salix alba (MFLU 15-2061, holotype). a Stromatal habit in wood. b Fruiting bodies on substrate. c Surface of fruiting bodies. d Cross section of the stroma showing conidiomata. e Peridium. f Ostioles. g-i Conidiogenous cells with intact conidia. $\mathrm{j}$ Mature conidia. $\mathrm{k}$ Germinating spore. $1, \mathrm{~m}$ Colonies on MEA (1-from above, mfrom below). Scale bars: $\mathrm{a}=2000 \mu \mathrm{m}, \mathrm{b}=1000 \mu \mathrm{m}, \mathrm{c}=400 \mu \mathrm{m}, \mathrm{d}=100 \mu \mathrm{m}, \mathrm{e}=50 \mu \mathrm{m}, \mathrm{f}=$ $100 \mu \mathrm{m}, \mathrm{g}, \mathrm{h}, \mathrm{i}, \mathrm{j}=10 \mu \mathrm{m}, \mathrm{k}=20 \mu \mathrm{m}$.

Culture characteristics - Colonies on MEA, reaching $9 \mathrm{~cm}$ diameter, after 7 days at 25 ${ }^{\circ} \mathrm{C}$, producing dense mycelium, circular, margin rough, white, lacking aerial mycelium.

Material examined - RUSSIA, Rostov Region, Krasnosulinsky District, Donskoye forestry, riparian forest, on dead and dying branches of Salix alba L. (Salicaceae), 18 June 2015, T. Bulgakov, T-508 (MFLU 15-2212, holotype, KUN, isotype), ex-type living culture, MFLUCC 15-0862, KUMCC; RUSSIA, Rostov Region, Krasnosulinsky District, Donskoye forestry, ravine spinney, on dying twigs and branches of Salix $\times$ rubens Schrank [S. alba L. $\times$ S. fragilis L.] (Salicaceae), 27 October 2015, T. Bulgakov, T-1017 (MFLU 15-3679, KUN), living culture, MFLUCC 16-0637, KUMCC. 


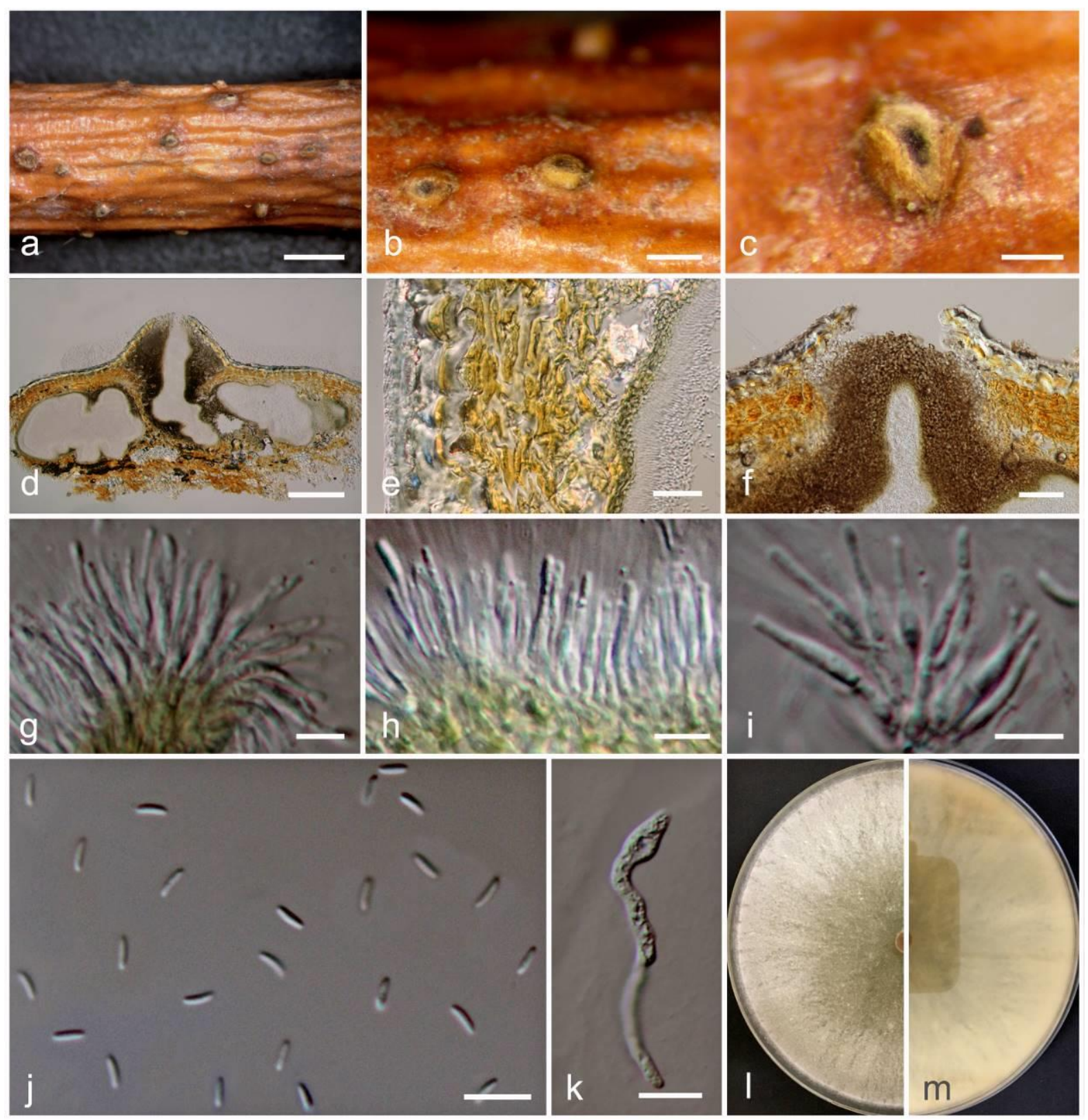

Fig. 17 - Cytospora salicina on Salix alba (MFLU 15-2212, holotype). a Stromatal habit in wood. b Fruiting bodies on substrate. c Surface of fruiting bodies. d Cross section of the stroma showing conidiomata. e Peridium. f Ostioles. g-i Conidiogenous cells with attached conidia. $\mathrm{j}$ Mature conidia. $\mathrm{k}$ Germinating spore. $1, \mathrm{~m}$ Colonies on MEA (l-from above, $\mathrm{m}$ from below). Scale bars: $\mathrm{a}=2000 \mu \mathrm{m}, \mathrm{b}=500 \mu \mathrm{m}, \mathrm{c}, \mathrm{d}=200 \mu \mathrm{m}, \mathrm{e}=20 \mu \mathrm{m}, \mathrm{f}=50 \mu \mathrm{m}, \mathrm{j}, \mathrm{k}$ $=10 \mu \mathrm{m}, \mathrm{g}, \mathrm{h}, \mathrm{i}=5 \mu \mathrm{m}$.

Notes - Cytospora salicina (MFLUCC 15-0862, MFLUCC 16-0637) was found on Salix spp. causing canker disease. Cytospora salicina is most similar to C. chrysosperma in having multi-locules, but differs in having smaller conidia $(4.6 \times 1.2 \mu \mathrm{m})$ and a peridium comprising several layers. Phylogenetic analysis based of combined ITS, LSU, RPB2 and ACT sequence data indicates that $C$. salicina can be distinguished from $C$. chrysosperma (HMBF17, HMBF151, HMBF158, HMBF159), C. melnikii (MFLUCC 15-0851, MFLUCC 16-0635) and $C$. salicacearum (MFLUCC 16-0509, MFLUCC 16-0587, MFLUCC 15-0861, MFLUCC 16-0576) (Fig. 2). 
In ITS, Cytospora salicina differs from C. chrysosperma with 28 polymorphisms, three polymorphisms from $C$. melnikii and a single polymorphism from $C$. salicacearum. In RPB2 it differs in 32 polymorphisms from $C$. chrysosperma, 30 polymorphisms from $C$. melnikii and 29 polymorphisms from $C$. salicacearum. In ACT it differs with ten polymorphism from $C$. melnikii and ten polymorphisms from $C$. salicacearum.

Cytospora sorbi Norphanphoun, Bulgakov, T.C. Wen \& K.D. Hyde, sp. nov. Index Fungorum number: IF552612, Facesoffungi Number: FoF 02750

Etymology: The specific epithet "sorbi" refers to the host plant genus Sorbus, on which the type specimen was first collected.

Holotype: MFLU 15-3781

Associated with twigs and branches of Sorbus aucuparia L. Sexual morph: Undetermined. Asexual morph: Conidiomata 900-1200 $\times$ 420-550 $\mu \mathrm{m}$ diameter, semiimmersed in host tissue, scattered, erumpent, with 3-4 locules, and ostiolar neck. Ostioles 250-300 $\mu \mathrm{m}$ diameter, at the same level as the disc surface. Peridium comprising a few to several layers of cells of textura angularis, with inner most layer thick, brown, outer dark brown. Conidiophores unbranched or occasionally branched at the base, reduced to conidiogenous cells. Conidiogenous cells blastic, enteroblastic, phialidic, formed from the inner most layer of pycnidial wall, hyaline, smooth-walled. Conidia (6-)6.4-7.6 × 1.4-1.5(1.8) $\mu \mathrm{m}(\overline{\mathrm{x}}=6.5 \times 1.5 \mu \mathrm{m}, \mathrm{n}=30)$, unicellular, elongate-allantoid, hyaline, smooth-walled.

Culture characteristics - Colonies on MEA, reaching $5 \mathrm{~cm}$ diameter after 7 days at 25 ${ }^{\circ} \mathrm{C}$, producing dense mycelium, circular, margin rough, white, lacking aerial mycelium.

Material examined - RUSSIA, Rostov Region, Krasnosulinsky District, Donskoye forestry, dying twigs and branches on Sorbus aucuparia (Rosaceae), 27 October 2015, T. Bulgakov, T-1119 (MFLU 15-3781, holotype, KUN, isotype), ex-type living culture, MFLUCC 16-0631, KUMCC.

Notes - Cytospora sorbi was collected from Sorbus aucuparia. In phylogenetic analysis (Figs. 1 and 2) C. sorbi forms a separate branch as a sister taxon to C. sorbicola and C. donetzica (Fig. 2). Cytospora sorbicola and C. donetzica differs from $C$. sorbi in having smaller conidia $(5.6 \times 1.5 \mu \mathrm{m}, 5.5 \times 1.4 \mu \mathrm{m}, 6.5 \times 1.5 \mu \mathrm{m}$, respectively $)$.

In ITS, Cytospora sorbi differs from $C$. sorbicola in eleven polymorphisms and eight polymorphisms from $C$. donetzica. In RPB2 it differs from $C$. sorbicola with 20 polymorphisms and 28 polymorphisms from $C$. donetzica. In ACT, it differs from $C$. sorbicola with nine polymorphisms and eight polymorphisms from $C$. donetzica.

Cytospora sorbicola Norphanphoun, Bulgakov, T.C. Wen \& K.D. Hyde, sp. nov. Fig. 19

Index Fungorum number: IF552613, Facesoffungi Number: FoF 02751

Etymology: The specific epithet "sorbicola" refers to the host plant genus Sorbus, on which the type specimens were collected.

Holotype: MFLU 15-2203

Associated with twigs and branches of Acer pseudoplatanus L. and Cotoneaster melanocarpus (Bunge) Loudon, Prunus cerasus L., Sorbus aucuparia L. and $\times$ Sorbaronia mitschurinii (Skvortsov \& Maitul.) Sennikov. Sexual morph: Undetermined. Asexual morph: Conidiomata 850-1200 × 480-600 $\mu \mathrm{m}$ diameter, semi-immersed in bark, solitary, erumpent, with 1-2 locules, ostiolate. Ostioles 250-350 $\mu \mathrm{m}$ diameter, at the same level as the disc surface. Peridium comprising several layers of cells of textura angularis, with inner most layer thick, pale brown, outer later dark brown. Conidiophores unbranched, reduced to conidiogenous cells. Conidiogenous cells blastic, enteroblastic, phialidic, formed from the 

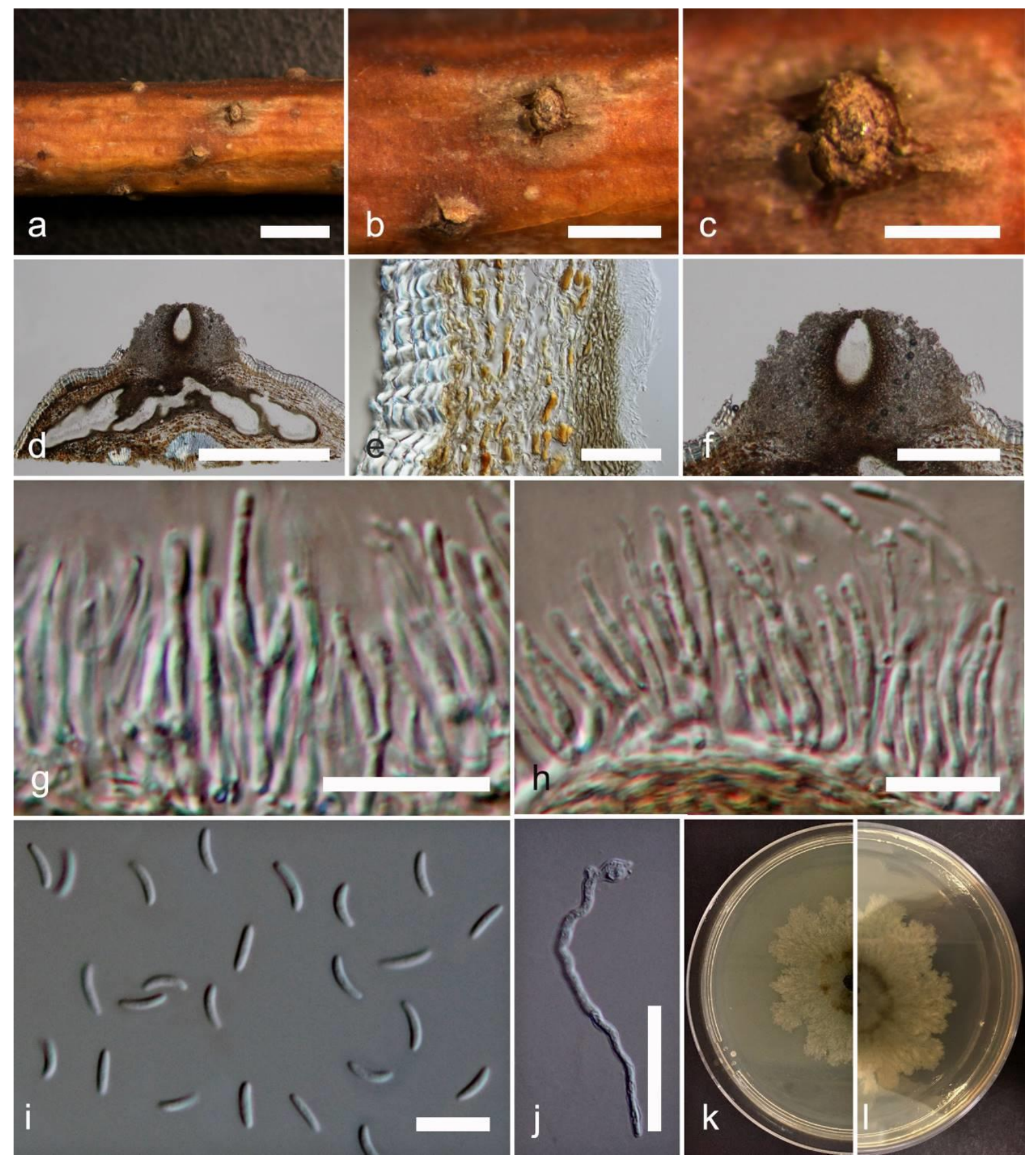

Fig. 18 - Cytospora sorbi on Sorbus aucuparia L. (MFLU 15-3781, holotype). a Stromatal habit in wood. b Fruiting bodies on substrate. c Surface of fruiting bodies. d Cross section of the stroma showing conidiomata. e Peridium. f Ostiolar neck. g-h Conidiogenous cells with attached conidia. i Mature conidia. j Germinating spore. k, l Colonies on MEA (k-from above, l-from below). Scale bars: $\mathrm{a}=2000 \mu \mathrm{m}, \mathrm{b}=1000 \mu \mathrm{m}, \mathrm{c}=500 \mu \mathrm{m}, \mathrm{d}=500 \mu \mathrm{m}, \mathrm{e}=$ $50 \mu \mathrm{m}, \mathrm{f}=200 \mu \mathrm{m}, \mathrm{g}=10 \mu \mathrm{m}, \mathrm{h}=10 \mu \mathrm{m}, \mathrm{i}=10 \mu \mathrm{m}$ and $\mathrm{j}=40 \mu \mathrm{m}$.

inner most layer of pycnidial wall, hyaline, smooth-walled. Conidia (4.4-)5.6-6.1 $\times 1.3-$ 1.5(-1.6) $\mu \mathrm{m}(\overline{\mathrm{x}}=5.6 \times 1.5 \mu \mathrm{m}, \mathrm{n}=30)$, unicellular, elongate-allantoid, slightly curved, hyaline, smooth-walled.

Culture characteristics - Colonies on MEA, reaching $8 \mathrm{~cm}$ diameter after 7 days at 25 ${ }^{\circ} \mathrm{C}$, producing dense mycelium, circular, margin rough, white, lacking aerial mycelium. 
Material examined - RUSSIA, Rostov Region, Krasnosulinsky District, Donskoye forestry, artificial forest, dead and dying branches on Acer pseudoplatanus (Sapindaceae), 18 June 2015, T. Bulgakov, T-499 (MFLU 15-2203, holotype, KUN, isotype), ex-type living culture, MFLUCC 16-0584, KUMCC; RUSSIA, Rostov Region, Rostov-on-Don City, Botanical Garden of Southern Federal University, parkland, on dead and dying branches on Sorbus aucuparia L. (Rosaceae), 30 May 2015, T. Bulgakov, T-472 (MFLU 15-2176, KUN), living culture, MFLUCC 16-0581, KUMCC; RUSSIA, Rostov Region, Rostov-on-Don City, Botanical Garden of Southern Federal University, Systematic Arboretum, on dead and dying branches on Cotoneaster melanocarpus (Bunge) Loudon (Rosaceae), 30 May 2015, T. Bulgakov, T-476 (MFLU 15-2180, KUN), living culture, MFLUCC 16-0582, KUMCC; RUSSIA, Rostov Region, Krasnosulinsky District, Donskoye forestry, old orchard, on dead and dying branches on Sorbaronia mitschurinii (Skvortsov \& Maitul.) Sennikov (Rosaceae), 18 June 2015, T. Bulgakov, T-501 (MFLU 15-2205, KUN), living culture, MFLUCC 160585, KUMCC; RUSSIA, Rostov Region, Krasnosulinsky District, Donskoye forestry, artificial forest platation, forest nursery, dead and dying branches on Prunus cerasus L. (Rosaceae), 18 June 2015, T. Bulgakov, T-502 (MFLU 15-2206, KUN), living culture, MFLUCC 16-0586, KUMCC; RUSSIA, Rostov Region, Krasnosulinsky District, Donskoye forestry, Kabanya Balka (Boar gully), steppe on slope of gully, dying twigs and branches (necrotrophic) on Cotoneaster melanocarpus Lodd., G. Lodd. \& W. Lodd., 27 October 2015, T. Bulgakov (MFLU 15-3768, KUN), living culture, MFLUCC 16-0633, KUMCC.

Notes - Six collections of Cytospora sorbicola (MFLUCC 16-0581, MFLUCC 160582, MFLUCC 16-0584, MFLUCC 16-0585, MFLUCC 16-0586, MFLUCC 16-0633) were made. Cytospora sorbicola is similar to $C$. donetzica and $C$. ceratosperma (Tode) G.C. Adams \& Rossman in conidia size $(5.6 \times 1.5 \mu \mathrm{m}, 5.5 \times 1.4 \mu \mathrm{m}, 5-6 \times 1.4 \mu \mathrm{m}$, respectively $)$ (Saccardo 1884), but $C$. donetzica differs in having multiloculate conidiomata and shorter ostiolar necks $(150-250 \mu \mathrm{m})$. Phylogenetic analysis (Figs. 1 and 2) place C. sorbicola in a separate clade from $C$. ceratosperma which is sister to $C$. donetzica (MFLUCC 16-0574, MFLUCC 15-0864, MFLUCC 16-0589, MFLUCC 16-0641) with bootstrap support (86\% MP/ 76\% ML/ $0.98 \mathrm{PP}$ ). Cytospora sorbicola differs from $C$. donetzica with five ITS polymorphisms, 23 RPB2 polymorphisms and seven ACT polymorphisms.

Cytospora ulmi Norphanphoun, Bulgakov, T.C. Wen \& K.D. Hyde, sp. nov.

Index Fungorum number: IF552614, Facesoffungi Number: FoF 02752

Fig. 20

Etymology: Name refers to the host genus Ulmus

Holotype: MFLU 15-1910

Associatd with twigs and branches of Ulmus minor. Sexual morph: Undetermined. Asexual morph: Conidiomata 980-1200 × 500-600 $\mu \mathrm{m}$ diameter, semi-immersed in host tissue, solitary, erumpent, scattered, discoid, circular to ovoid, with 4-6 locules, with long ostiolar neck. Ostioles $410-450 \mu \mathrm{m}$, at the same level as the disc surface. Peridium comprising a few to several layers of cells of textura angularis, with inner most layer thin, pale brown. Conidiophores branched, reduced to conidiogenous cells. Conidiogenous cells blastic, enteroblastic, phialidic, hyaline, smooth-walled. Conidia (4.8-)5.4-6.4 × 1.3-1.5(1.6) $\mu \mathrm{m}(\overline{\mathrm{x}}=5.4 \times 1.4 \mu \mathrm{m}, \mathrm{n}=30)$, unicellular, elongate-allantoid, hyaline, smooth-walled.

Culture characteristics - Colonies on MEA, reaching $6 \mathrm{~cm}$ diameter after 7 days at 25 ${ }^{\circ} \mathrm{C}$, producing dense mycelium, circular, margin rough, white, lacking aerial mycelium.

Material examined - RUSSIA, Rostov Region, Krasnosulinsky District, Donskoye forestry, ravine forest, on dead and dying branches (necrotrophic/saprobic) of Ulmus minor Mill., 28 June 2015, T. Bulgakov, T-521 (MFLU 15-2225, holotype, KUN, isotype), ex-type living culture, MFLUCC 15-0863, KUMCC. 

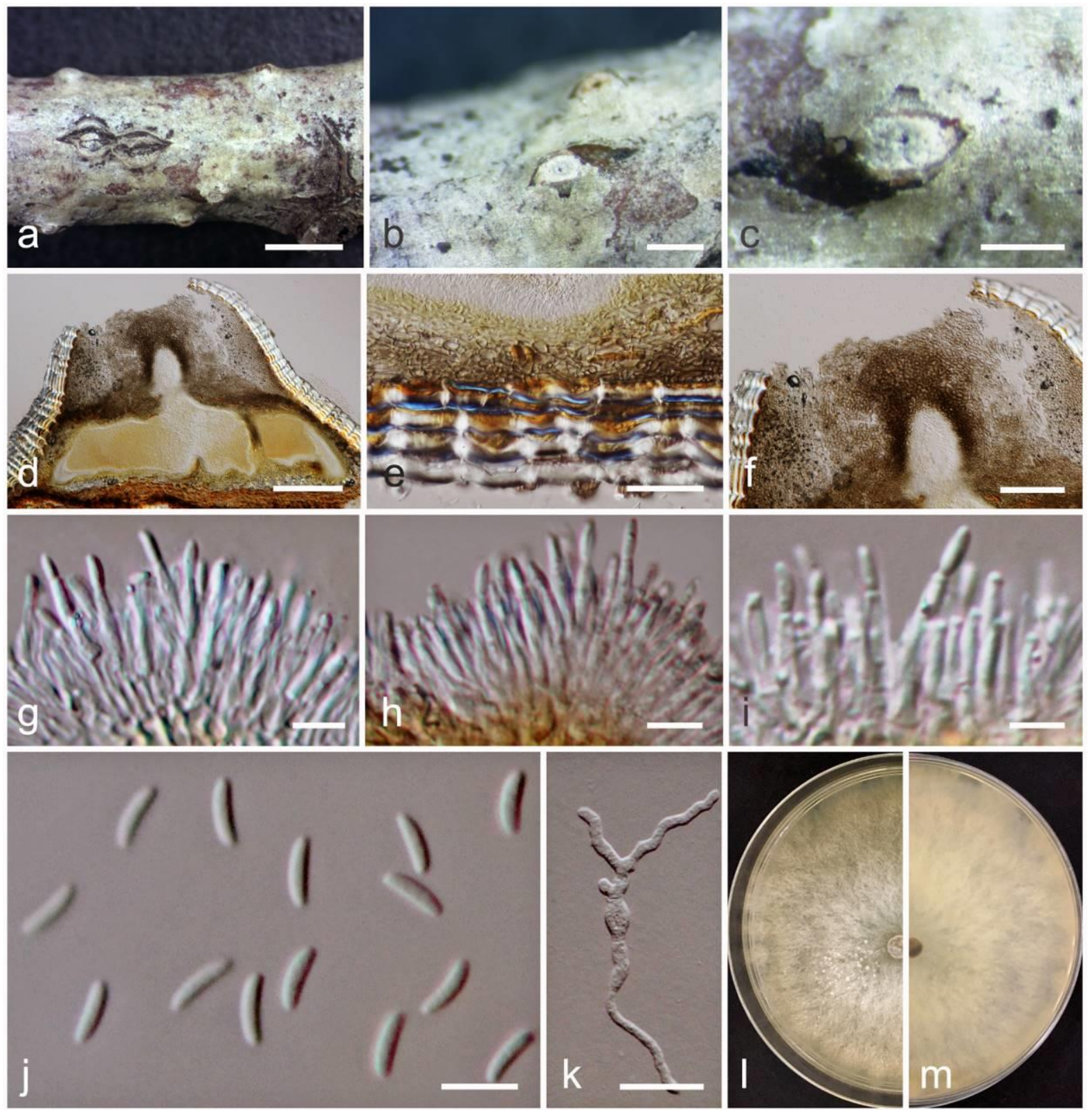

Fig. 19 - Cytospora sorbicola on Acer pseudoplatanus (MFLU 15-2203, holotype). a Stromatal habit in wood. b Fruiting bodies on substrate. c Surface of stroma. d Vertical section of the stroma showing conidiomata. e Peridium. f Ostiolar neck. g-i Conidiogenous cells with attached conidia. $\mathrm{j}$ Mature conidia. $\mathrm{k}$ Germinating spore. $1, \mathrm{~m}$ Colonies on MEA (1from above, $\mathrm{m}$-from below). Scale bars: $\mathrm{a}=2000 \mu \mathrm{m}, \mathrm{b}, \mathrm{c}=500 \mu \mathrm{m}, \mathrm{d}=200 \mu \mathrm{m}, \mathrm{e}=50 \mu \mathrm{m}$, $\mathrm{f}=100 \mu \mathrm{m}, \mathrm{g}, \mathrm{h}, \mathrm{i}, \mathrm{j}=5 \mu \mathrm{m}, \mathrm{k}=10 \mu \mathrm{m}$.

Notes - Phylogenetic analysis of four combined gene loci indicate that Cytospora ulmi (MFLUCC 15-0863), forms a distinct branch as a sister taxon to C. ribis Ehrenb. (284-2) isolated from Thuja orientalis L., C. rosarum Grev. (218) isolated from Rosa canina L. and C. tanaitica Norphanphoun, Bulgakov \& Hyde (MFLUCC 14-1057) isolated from Betula pubescens Ehrh. (Fig. 2) (Adams et al. 2002, Ariyawansa et al. 2015, Fotouhifar et al. 2010).

Cytospora ulmi is most similar to $C$. rosarum in having long conidia ((4.8-)5.4-6.4 $\mu \mathrm{m}$ versus $4.5-6.7 \mu \mathrm{m})$, but has narrower conidia $(1.3-1.5(-1.6) \mu \mathrm{m}$ versus $0.9-1.1 \mu \mathrm{m})$. Cytospora ribis and $C$. tanaitica are similar to $C$. ulmi in having multi-loculate conidiomata. However, C. ulmi $(5.4 \times 1.4 \mu \mathrm{m})$ has larger conidia than $C$. ribis $(4 \times 1 \mu \mathrm{m})$ and $C$. tanaitica $(3.4 \times 0.7 \mu \mathrm{m})($ Adams et al. 2002, Fotouhifar et al. 2010, Ariyawansa et al. 2015). 

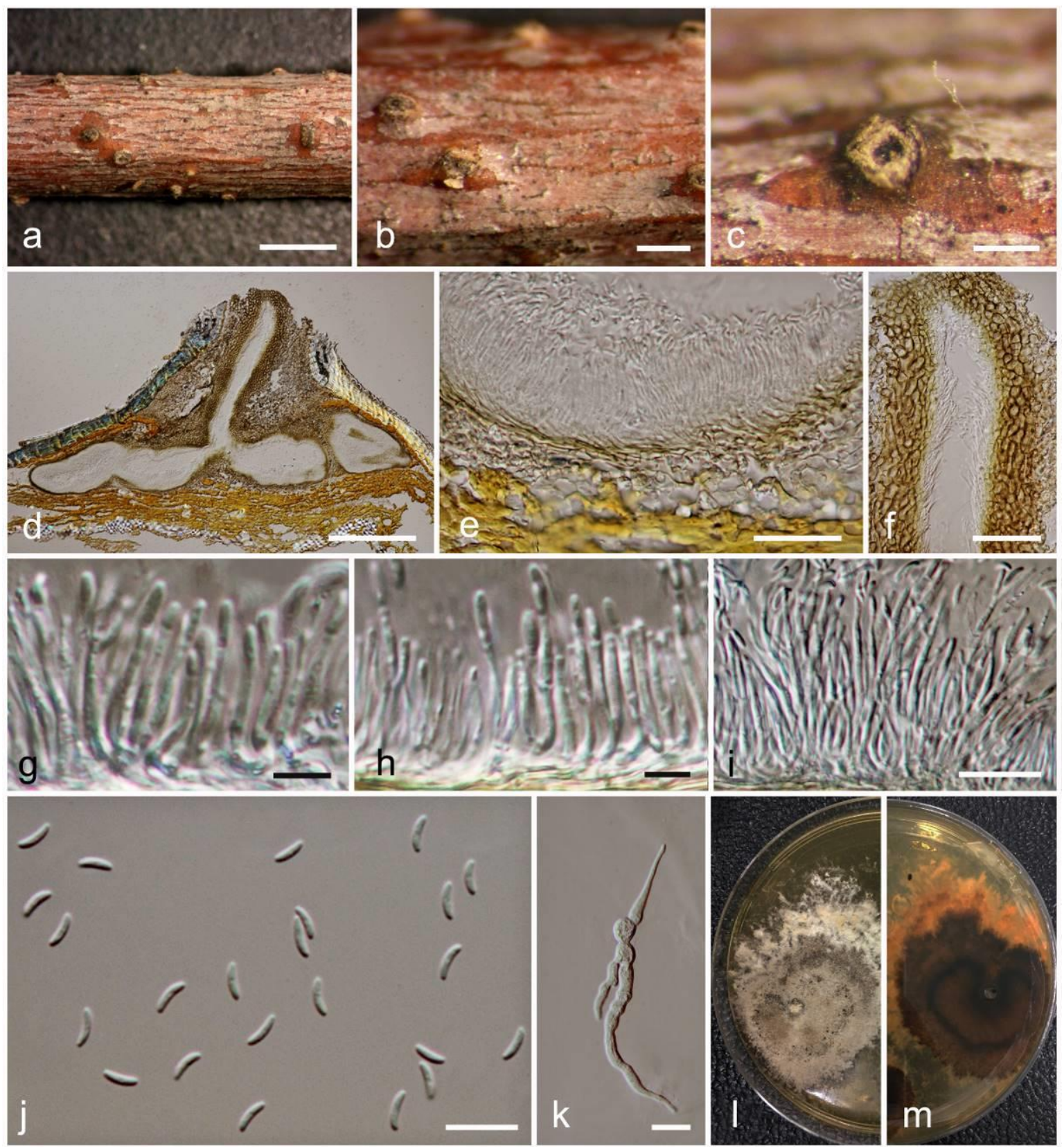

Fig. 20 - Cytospora ulmi (MFLU 15-2225, holotype). a Stromatal habit in wood. b Fruiting bodies on substrate. c Surface of fruiting bodies. d Cross section of the stroma showing conidiomata. e Peridium. f Ostiolar neck. g-i Conidiogenous cells with attached conidia. j Mature conidia. $\mathrm{k}$ Germinating spore. $1, \mathrm{~m}$ Colonies on MEA (l-from above, $\mathrm{m}$-from below). Scale bars: $\mathrm{a}=2000 \mu \mathrm{m}, \mathrm{b}=500 \mu \mathrm{m}, \mathrm{c}, \mathrm{d}=200 \mu \mathrm{m}, \mathrm{e}, \mathrm{f}=50 \mu \mathrm{m}, \mathrm{g}, \mathrm{h}=5 \mu \mathrm{m}, \mathrm{i}, \mathrm{j}=10 \mu \mathrm{m}, \mathrm{k}$ $=20 \mu \mathrm{m}$.

\section{Discussion}

Cytospora species are important plant pathogens causing dieback and canker disease with a worldwide distribution and host range including Armeniaca, Eucalyptus, Fraxinus, Ligustrum, Malus, Mangifera, Platanus, Populus, Punus, Robinia, Salix and Ulmus to name a few (Adam et al. 2006, Fotouhifar et al. 2010, Ariyawansa et al. 2015, Fan et al. 2015a, 2015b, Liu et al. 2015, Li et al. 2016, Maharachchikumbura et al. 2015, 2016, Hyde et al. 2016). In this study, all samples were collected from European Russia from dying twigs and symptomatic branches. 
A phylogenetic analysis was constructed using maximum parsimony, maximum likelihood and Bayesian inference for an individual ITS dataset and was able to resolve some species of Cytospora (Fig. 1). However, the combined analysis of ITS, LSU, RPB2 and ACT sequence was more appropriate for resolving Cytospora species (Fig. 2). It has repeatedly been shown that multi-gene dataset will resolve species in pathogenic (e.g. Colletotrichum, Cai et al. 2009, Diaporthe, Udayanga et al. 2011, 2015, Pestalotiopsis, Maharachchikumbura et al. 2011, 2012) and other genera (e.g. Stachybotrys, Lombard et al. 2016, Nodulosphaeria, Mapook et al. 2016, Lasiodiplodia, Doilom et al. 2017), better than single genes.

Species of Cytospora may be relatively host-specific (Zhou et al. 2001), such as $C$. australiae Speg., C. eucalyptina Speg., C. eucalypticola Van der Westh., and C. agarwalii Soni, Dadwal \& Jamaluddin which have only been reported from Eucalyptus sp. (Adams et al. 2005). Previous reports have however, indicated that many Cytospora species have broad host ranges. However, those reports lacked identifications based on molecular data (Fries 1823, Deng 1963, Saccardo 1884, Tai 1979, Wei 1979). Some widespread species have been identified and verified by molecular data to occur in many host species, such as $C$. chrysosperma and $C$. nivea (Adams et al. 2005, Fan et al. 2014, Ariyawansa et al. 2015, Fan et al. 2015a, 2015b, Liu et al. 2015, Maharachchikumbura et al. 2015, 2016, Hyde et al. 2016, Li et al. 2016,). In Table 3 we summarize the species (identified with sequence data) and their host distribution.

Our study provides data on the distribution of 17 Cytospora species with a multi-gene phylogeny. Several hosts appear to support several Cytospora species and several Cytospora species are known from several hosts (Table 3). Some taxa on the other hand, are only known from a single host. Thus we regard the data we provide on Cytospora are preliminary and future studies are likely establish numerous new species and further resolve their distribution.

\section{Acknowledgements}

We would like to thank the Mushroom Research Foundation, Chiang Rai, Thailand, and the Science and Technology Foundation of Guizhou Province (No. [2012]3173) for supporting this research. Thanks for Saowaluck Tibpromma, Shaun Pennycook, Chathumini Jayasiri, Chen Yun, Yuan-Pin Xiao, Sinang Hongsanan, Saranyaphat Boonmee, and Sirinapa Konta for informative name information and general assistance.

\section{References}

Adams GC, Roux J, Wingfield MJ. 2006 - Cytospora species (Ascomycota, Diaporthales, Valsaceae): introduced and native pathogens of trees in South Africa. Australasian Plant Pathology 35, 521-548.

Adams GC, Surve-Iyer RS, Iezzoni A. 2002 - Ribosomal DNA sequence divergence and group I introns within Leucostoma species, L. cinctum, L. persoonii, and $L$. parapersoonii sp. nov., ascomycetes that cause Cytospora canker of fruit trees. Mycologia 94, 947-967.

Adams GC, Wingfield MJ, Common R, Roux J. 2005 - Phylogenetic relationships and morphology of Cytospora species and related teleomorphs (Ascomycota, Diaporthales, Valsaceae) from Eucalyptus. Studies in Mycology 52, 1-144.

Ariyawansa HA, Hyde KD, Jayasiri SC, Buyck B et al. 2015 - Fungal diversity notes 111252 - taxonomic and phylogenetic contributions to fungal taxa. Fungal Diversity 75, $27-274$. 
Table 3 Occurrence of Cytospora species on hosts (species identifications confirmed with molecular data)

\begin{tabular}{|c|c|c|c|}
\hline Host & Species record & Genes used & References \\
\hline \multirow[t]{2}{*}{ Abies } & Valsa abietis & ITS & Adams et al. (2005) \\
\hline & Valsa friesii & ITS & Défago (1942) \\
\hline Acacia & Cytospora sp. "Uncertain lineage" & ITS & Adams et al. (2006) \\
\hline \multirow[t]{5}{*}{ Acer } & Cytospora ampulliformis & ITS, LSU, RPB2, ACT & In this study \\
\hline & Cytospora rosarum & ITS, LSU, RPB2, ACT & Tibpromma et al. (personal comm) \\
\hline & Cytospora sorbicola & ITS, LSU, RPB2, ACT & In this study \\
\hline & Valsa ambiens subsp. ambiens & ITS & Spielman (1985) \\
\hline & Valsa ambiens subsp. leucostomoides & ITS & Spielman (1985) \\
\hline \multirow[t]{2}{*}{ Amygdalus } & Cytospora cincta & ITS & Fotouhifar et al. (2010) \\
\hline & Cytospora leucosperma & ITS & Fotouhifar et al. (2010) \\
\hline \multirow[t]{4}{*}{ Armeniaca } & Cytospora chrysosperma & ITS & Fotouhifar et al. (2010) \\
\hline & Cytospora cincta & ITS & Fotouhifar et al. (2010) \\
\hline & Cytospora cinctum & ITS & $\begin{array}{l}\text { Adams et al. (2002, 2005, 2006), Fotouhifar et al. } \\
\text { (2010), Singh et al. (2007) }\end{array}$ \\
\hline & Cytospora leucostoma & ITS & Fotouhifar et al. (2010) \\
\hline Berberis & Cytospora berberidis & ITS, LSU, RPB2, ACT & Liu et al. (2015) \\
\hline Betula & Cytospora tanaitica & ITS, LSU, ACT & Ariyawansa et al. (2015) \\
\hline Celtis & Cytospora translucens & ITS & Fotouhifar et al. (2010) \\
\hline \multirow[t]{2}{*}{ Cerasus } & Cytospora cincta & ITS & Fotouhifar et al. (2010) \\
\hline & Cytospora schulzeri & ITS & Fotouhifar et al. (2010) \\
\hline Ceratonia & Cytospora acacia African-Mediterranean lineage & ITS & Adams et al. (2006) \\
\hline Cercis & Valsa viridistroma comb. nov. & ITS & Wehmeyer (1936) \\
\hline Chamaecyparis & Valsa abietis sp. complex 1 (syn. Valsa weiriana) & ITS & Adams et al. (2002) \\
\hline Colutea & Cytospora schulzeri & ITS & Fotouhifar et al. (2010) \\
\hline \multirow[t]{2}{*}{ Cotinus } & Cytospora cotini & ITS, LSU, RPB2, ACT & Hyde et al. (2016) \\
\hline & Cytospora gelida & ITS, LSU, RPB2, ACT & Tibpromma et al. (personal comm) \\
\hline Cotoneaster & Cytospora sorbicola & ITS, LSU, RPB2, ACT & In this study \\
\hline \multirow[t]{5}{*}{ Crataegus } & Cytospora chrysosperma & ITS & Fotouhifar et al. (2010) \\
\hline & Cytospora cincta & ITS & Fotouhifar et al. (2010) \\
\hline & Cytospora donetzica & ITS, LSU, RPB2, ACT & In this study \\
\hline & Cytospora malicola & ITS & Fotouhifar et al. (2010) \\
\hline & Cytospora schulzeri & ITS & Fotouhifar et al. (2010) \\
\hline \multirow[t]{2}{*}{ Cydonia } & Cytospora cincta & ITS & Fotouhifar et al. (2010) \\
\hline & Cytospora cinctum & ITS & Fotouhifar et al. (2010) \\
\hline \multirow[t]{3}{*}{ Elaeagnus } & Cytospora elaeagni & ITS, LSU, RPB2, ACT & Fan et al. (2015b) \\
\hline & Cytospora nivra & ITS, LSU, RPB2, ACT & Fan et al. (2015b) \\
\hline & Cytospora ribis & ITS & Fotouhifar et al. (2010) \\
\hline Eriobotrya & Cytospora eriobotryae & ITS & Adams et al. $(2005,2006)$ \\
\hline
\end{tabular}




\begin{tabular}{|c|c|c|c|}
\hline Host & Species record & Genes used & References \\
\hline \multirow[t]{25}{*}{ Eucaliptus } & Cytospora abyssinica & ITS & Adams et al. (2005) \\
\hline & Cytospora aff. austromontana & ITS & Adams et al. (2005) \\
\hline & Cytospora agarwalii & ITS & Adams et al. (2005) \\
\hline & Cytospora australiae & ITS & Adams et al. (2005) \\
\hline & Cytospora austromontana & ITS & Adams et al. (2005) \\
\hline & Cytospora berkeleyi & ITS & Adams et al. (2005) \\
\hline & Cytospora chrysosperma & ITS & Adams et al. (2005) \\
\hline & Cytospora diatrypelloideae & ITS & Adams et al. (2005) \\
\hline & Cytospora disciformis & ITS & Adams et al. (2005) \\
\hline & Cytospora eucalypticola & ITS & Adams et al. $(2005,2006)$ \\
\hline & Cytospora-like species & ITS & Adams et al. (2005) \\
\hline & Cytospora nitschkii & ITS & Adams et al. (2005) \\
\hline & Cytospora putative & ITS & Smith et al. (1996) \\
\hline & Cytospora putative species 1 & ITS & Adams et al. (2005) \\
\hline & Cytospora valsoidea & ITS & Adams et al. (2005) \\
\hline & Cytospora variostromatica & ITS & Adams et al. (2005) \\
\hline & Valsa aff. cinereostroma (Cytospora austealia) & ITS & Crous et al. (1990) \\
\hline & Valsa brevispora & ITS & Adams et al. (2005) \\
\hline & Valsa cinereostroma & ITS & Adams et al. (2005) \\
\hline & Valsa eucalypti & ITS & Adams et al. (2005) \\
\hline & Valsa eugeniae & ITS & Adams et al. (2005) \\
\hline & Valsa fabianae & ITS & Adams et al. (2005) \\
\hline & Valsa luecostoma & ITS & Adams et al. (2002) \\
\hline & Vala myrtagena & ITS & Adams et al. (2005) \\
\hline & Valsa salicina & ITS & Adams et al. (2006) \\
\hline \multirow[t]{2}{*}{ Eugenia } & Valsa eugeniae & ITS & Adams et al. (2005) \\
\hline & Valsa eugeniae & ITS & Sivanesan and Holliday (19701) \\
\hline Fagus & Cytospora decorticans & ITS & Adams et al. (2005) \\
\hline Ficus & Cytospora chrysosperma & ITS & Fotouhifar et al. (2010) \\
\hline \multirow[t]{4}{*}{ Fraxinus } & Cytospora chrysosperma & ITS & Fotouhifar et al. (2010) \\
\hline & Cytospora minuta & ITS & Adams et al. (2006) \\
\hline & Cytospora pruinosa & ITS & Fotouhifar et al. (2010) \\
\hline & Valsa cypri & ITS & Défago (1942) \\
\hline Hippophae & Cytospora hippophaes & ITS, LSU, RPB2, ACT & Fan et al. (2015b) \\
\hline \multirow[t]{2}{*}{ Jacaranda } & Valsa ceratosperma & ITS & Adams et al. (2006) \\
\hline & Cytospora atrocirrhata & ITS, LSU, TUB2, ACT & Fan et al. (2015a) \\
\hline \multirow[t]{5}{*}{ Juglans } & Cytospora chrysosperma & ITS & Fotouhifar et al. (2010) \\
\hline & Cytospora chrysosperma & ITS, LSU, TUB2, ACT & Fan et al. (2015a) \\
\hline & Cytospora cincta & ITS & Fotouhifar et al. (2010) \\
\hline & Cytospora gigaspora & ITS, LSU, TUB2, ACT & Fan et al. $(2015 a)$ \\
\hline & Cytospora leucostoma & ITS & Fotouhifar et al. (2010) \\
\hline
\end{tabular}




\begin{tabular}{|c|c|c|c|}
\hline Host & Species record & Genes used & References \\
\hline & Cytospora sacculus & ITS, LSU, TUB2, ACT & Fan et al. (2015a) \\
\hline & Cytospora sordida & ITS & Fotouhifar et al. (2010) \\
\hline Lepidium & Cytospora ribis & ITS & Fotouhifar et al. (2010) \\
\hline Ligustrum & Cytospora chrysosperma & ITS & Fotouhifar et al. (2010) \\
\hline \multirow{14}{*}{ Malus } & Cytospora ceratosperma & ITS & Adams et al. (2005) \\
\hline & Cytospora chrysosperma & ITS & Fotouhifar et al. (2010), Mehrabi et al. (2011) \\
\hline & Cytospora cincta & ITS & Fotouhifar et al. (2010), Mehrabi et al. (2011) \\
\hline & Cytospora cinctum & ITS & Fotouhifar et al. (2010) \\
\hline & Cytospora lucostoma & ITS & Mehrabi et al. (2011) \\
\hline & Cytospora malicola & ITS & $\begin{array}{l}\text { Adams et al. (2002, 2005, 2006), Fotouhifar et al. } \\
\text { (2010), Singh et al. (2007) }\end{array}$ \\
\hline & Cytospora melnikii & ITS, LSU, RPB2, ACT & In this study \\
\hline & Cytospora parasitica & ITS, LSU, RPB2, ACT & In this study , Ariyawansa et al. (2015) \\
\hline & Cytospora schulzeri & ITS & Fotouhifar et al. (2010), Mehrabi et al. (2011) \\
\hline & Valsa cincta & ITS & Adams et al. (2002) \\
\hline & Valsa mali & ITS & Adams et al. (2002) \\
\hline & Valsa malicola & ITS & Adams et al. (2002) \\
\hline & Valsa melostoma & ITS & Adams et al. (2002) \\
\hline & Valsa nivea & ITS & Adams et al. (2006) \\
\hline Mangifera & Valsa cinereostroma (Cytospora) & ITS & Adams et al. (2005) \\
\hline \multirow[t]{3}{*}{ Morus } & Cytospora chrysosperma & ITS & Fotouhifar et al. (2010) \\
\hline & Cytospora cypsi & ITS & Fotouhifar et al. (2010) \\
\hline & Cytospora pruinosa & ITS & Fotouhifar et al. (2010) \\
\hline \multirow[t]{2}{*}{ Olea } & Cytospora chrysosperma & ITS & Fotouhifar et al. (2010) \\
\hline & Valsa cypri & ITS & $\begin{array}{l}\text { Adams et al. (2002, 2005, 2006), Fotouhifar et al. } \\
\text { (2010), Singh et al. (2007) }\end{array}$ \\
\hline \multirow[t]{2}{*}{ Persica } & Cytospora chrysosperma & ITS & Fotouhifar et al. (2010) \\
\hline & Cytospora leucostoma & ITS & Fotouhifar et al. (2010) \\
\hline \multirow[t]{3}{*}{ Picea } & Cytospora mougeotii & ITS & Adams et al. (2005) \\
\hline & Valsa kunzei & ITS & Adams et al. (2005) \\
\hline & Valsa kunzei var. piceae & ITS & Proffer and Hart (1988) \\
\hline Pistacia & Cytospora terebinthi & ITS & Fotouhifar et al. (2010) \\
\hline \multirow[t]{3}{*}{ Pinus } & Valsa friesii & ITS & Adams et al. (2005) \\
\hline & Valsa kunzei & ITS & Adams et al. (2006) \\
\hline & Valsa pini & ITS & Adams et al. (2005), Défago (1942) \\
\hline \multirow[t]{4}{*}{ Platanus } & Cytospora chrysosperma & ITS & Fotouhifar et al. (2010) \\
\hline & Cytospora gutnerae & ITS & Fotouhifar et al. (2010) \\
\hline & Cytospora nivea & ITS & Fotouhifar et al. (2010) \\
\hline & Cytospora ribis & ITS & Fotouhifar et al. (2010) \\
\hline \multirow[t]{2}{*}{ Populus } & Cytospora atrocirrhata & ITS & Fotouhifar et al. (2010) \\
\hline & Cytospora chrysosperma & ITS & Adams et al. $(2002,2005,2006)$, Fotouhifar et al. \\
\hline
\end{tabular}




\begin{tabular}{|c|c|c|c|}
\hline Host & Species record & Genes used & References \\
\hline & & & (2010), Singh et al. (2007) \\
\hline & Cytospora fugax & ITS & Fotouhifar et al. (2010) \\
\hline & Cytospora germanica & ITS & Adams et al. (2006) \\
\hline & Cytospora hariotii & ITS & Adams et al. (2006) \\
\hline & Cytospora kantschavelii & ITS & Fotouhifar et al. (2010) \\
\hline & Cytospora melnikii & ITS, LSU, RPB2, ACT & In this study \\
\hline & Cytospora nivea & ITS & Adams et al. (2006) \\
\hline & Cytospora parakantschavelii & ITS, LSU, RPB2, ACT & In this study \\
\hline & Cytospora paratranslucens & ITS, LSU, RPB2, ACT & In this study \\
\hline & Cytospora rusanovii & ITS, LSU, RPB2, ACT & In this study \\
\hline & Cytospora salicacearum & ITS, LSU, RPB2, ACT & In this study \\
\hline & Cytospora sordida & ITS & $\begin{array}{l}\text { Adams et al. (2002, 2005, 2006), Fotouhifar et al. } \\
\text { (2010), Singh et al. (2007) }\end{array}$ \\
\hline & Cytospora translucens & ITS & Fotouhifar et al. (2010) \\
\hline & Cytospora variostromatica & ITS & Adams et al. (2006) \\
\hline & Valsa nivea & ITS & Défago (1942), Fotouhifar et al. (2010) \\
\hline \multirow[t]{11}{*}{ Prunus (Sakura) } & Cytospora salicacearum & ITS, LSU, RPB2, ACT & In this study \\
\hline & Cytospora sorbicola & ITS, LSU, RPB2, ACT & In this study \\
\hline & Cytospora chrysosperma & ITS & Fotouhifar et al. (2010) \\
\hline & Cytospora cincta & ITS & Fotouhifar et al. (2010) \\
\hline & Cytospora cinctum & ITS & Fotouhifar et al. (2010) \\
\hline & Cytospora persoonii & ITS & Fotouhifar et al. (2010) \\
\hline & Cytospora leucostoma & ITS & Adams et al. (2002) \\
\hline & Valsa cincta & ITS & Adams et al. (2002) \\
\hline & Valsa leucostoma f. sp. insititiae & ITS & Défago (1942) \\
\hline & Cytospora eutypelloides & ITS & Adams et al. (2006) \\
\hline & Valsa parapersoonii comb. Nov. & ITS & Adams et al. (2006) \\
\hline Pseudotsuga & Valsa abietis sp. complex 1 (syn. Valsa weiriana) & ITS & Adams et al. (2002) \\
\hline \multirow[t]{4}{*}{ Pyrus } & Cytospora donetzica & ITS, LSU, RPB2, ACT & In this study \\
\hline & Cytospora parakantschavelii & ITS, LSU, RPB2, ACT & In this study \\
\hline & Cytospora sacculus & ITS & Fotouhifar et al. (2010) \\
\hline & Valsa ceratosperma & ITS & Fotouhifar et al. (2010) \\
\hline \multirow[t]{3}{*}{ Quercus } & Cytospora intermedia & ITS & Fotouhifar et al. (2010) \\
\hline & Cytospora sacculus & ITS & Adams et al. (2005) \\
\hline & Valseutypella multicollis & ITS & Adams et al. (2006) \\
\hline Rhododendron & Valsa subclypeata & ITS & Adams et al. (2005) \\
\hline Rhus & Valsa ceratosperma s.lat. & ITS & Adams et al. (2005) \\
\hline Ribes & Cytospora ribis & ITS & $\begin{array}{l}\text { Adams et al. (2002, 2005, 2006), Fotouhifar et al. } \\
\text { (2010), Singh et al. (2007) }\end{array}$ \\
\hline \multirow[t]{2}{*}{ Rosa } & Cytospora cincta & ITS & Fotouhifar et al. (2010) \\
\hline & Cytospora donetzica & ITS, LSU, RPB2, ACT & In this study \\
\hline
\end{tabular}




\begin{tabular}{|c|c|c|c|}
\hline Host & Species record & Genes used & References \\
\hline & Cytospora leucostoma & ITS & Fotouhifar et al. (2010) \\
\hline & Cytospora rhodophila & ITS & $\begin{array}{l}\text { Adams et al. (2002, 2005, 2006), Fotouhifar et al. } \\
\text { (2010), Singh et al. (2007) }\end{array}$ \\
\hline & Cytospora rosarum & ITS & Fotouhifar et al. (2010) \\
\hline \multirow[t]{2}{*}{ Robinia } & Cytospora chrysosperma & ITS & Fotouhifar et al. (2010) \\
\hline & Cytospora leucostoma & ITS & Fotouhifar et al. (2010) \\
\hline Saccharum & Cytospora sacchari & ITS & $\begin{array}{l}\text { Adams et al. (2002, 2005, 2006), Fotouhifar et al. } \\
\text { (2010), Singh et al. (2007) }\end{array}$ \\
\hline \multirow[t]{21}{*}{ Salix } & Cytospora atrocirrhata & ITS & Fotouhifar et al. (2010) \\
\hline & Cytospora aurora & ITS & Fotouhifar et al. (2010) \\
\hline & Cytospora curvata & ITS, LSU, RPB2, ACT & In this study \\
\hline & Cytospora chrysosperma & ITS, LSU, RPB2, ACT & Fan et al. (2015b) \\
\hline & Cytospora donetzica & ITS, LSU, RPB2, ACT & In this study \\
\hline & Cytospora erumpens & ITS, LSU, RPB2, ACT & In this study \\
\hline & Cytospora fugax & ITS & Fotouhifar et al. (2010) \\
\hline & Cytospora gigaspora & ITS, LSU, RPB2, ACT & Fan et al. (2015b) \\
\hline & Cytospora longiostiolata & ITS, LSU, RPB2, ACT & In this study \\
\hline & Cytospora nivea & ITS, LSU, RPB2, ACT & In this study, Fan et al. (2015b) \\
\hline & Cytospora populina & ITS, LSU, RPB2, ACT & Fan et al. (2015b) \\
\hline & Cytospora rusanovii & ITS, LSU, RPB2, ACT & In this study \\
\hline & Cytospora salicacearum & ITS, LSU, RPB2, ACT & In this study \\
\hline & Cytospora salicina & ITS, LSU, RPB2, ACT & In this study \\
\hline & Cytospora salicacearum & ITS, LSU, RPB2, ACT & In this study \\
\hline & Cytospora salicicola & ITS, LSU, RPB2, ACT & In this study, Li et al. (2016) \\
\hline & Cytospora salicina & ITS, LSU, RPB2, ACT & In this study \\
\hline & Leucostoma translucens & ITS & Fotouhifar et al. (2010) \\
\hline & Valsa salicina & ITS & Defago (1942), Fotouhifar et al. (2010) \\
\hline & Valsa sordida & ITS & Adams et al. (2006), Fotouhifar et al. (2010) \\
\hline & Valsa translucens & ITS & Defago (1942) \\
\hline Sequoia & Cytospora eucalypti & ITS & Adams et al. (2005) \\
\hline Sibiraea & Cytospora sibiraeae & ITS, LSU, RPB2, ACT & Liu et al. (2015) \\
\hline \multirow[t]{3}{*}{ Sophora } & Cytospora chrysosperma & ITS & Dar \&Rai (2014) \\
\hline & Cytospora sophorae & ITS & Dar \&Rai (2014) \\
\hline & Cytospora sophoricola & ITS & Dar \&Rai (2014) \\
\hline Sorbaronia & Cytospora sorbicola & ITS, LSU, RPB2, ACT & In this study \\
\hline \multirow[t]{5}{*}{ Sorbus } & Cytospora ampulliformis & ITS, LSU, RPB2, ACT & In this study \\
\hline & Cytospora leucostoma & ITS & Adams et al. (2005) \\
\hline & Cytospora sorbicola & ITS, LSU, RPB2, ACT & In this study \\
\hline & Cytospora sorbi & ITS, LSU, RPB2, ACT & In this study \\
\hline & Valsa massariana & ITS & Adams et al. (2002) \\
\hline Syringa & Valsa cypri & ITS & Défago (1942) \\
\hline
\end{tabular}




\begin{tabular}{|c|c|c|c|}
\hline Host & Species record & Genes used & References \\
\hline Tamarix & Cytospora chrysosperma & ITS & Fotouhifar et al. (2010) \\
\hline \multirow[t]{2}{*}{ Taxus } & Valsa ambiens & ITS & Adams et al. (2005), Défago (1942) \\
\hline & Valsa ceratophora & ITS & Adams et al. (2005), Défago (1942) \\
\hline \multirow{3}{*}{ Thuja } & Cytospora chrysosperma & ITS & Fotouhifar et al. (2010) \\
\hline & Cytospora ribis & ITS & Fotouhifar et al. (2010) \\
\hline & Cytospora schulzeri & ITS & Fotouhifar et al. (2010) \\
\hline \multirow[t]{2}{*}{ Tibouchina } & Valsa eugeniae (Cytospora state) & ITS & Adams et al. (2005) \\
\hline & Valsa myrtagena & ITS & Fotouhifar et al. (2010) \\
\hline Triticum & Cytospora tritici & ITS & Adams et al. (2006) \\
\hline \multirow[t]{4}{*}{ Ulmus } & Cytospora carbonacea & ITS & $\begin{array}{l}\text { Adams et al. (2002, 2005, 2006), Fotouhifar et al. } \\
\text { (2010), Singh et al. (2007) }\end{array}$ \\
\hline & Cytospora eutypelloides & ITS & Défago (1942) \\
\hline & Cytospora subclypeata & ITS & Adams et al. (2005) \\
\hline & Cytospora ulmi & ITS, LSU, RPB2, ACT & In this study \\
\hline \multirow{2}{*}{ Vitis } & Cytospora cincta & ITS & Fotouhifar et al. (2010) \\
\hline & Cytospora leucostoma & ITS & Fotouhifar et al. (2010) \\
\hline
\end{tabular}


Bulgakov TS. 2010 - Microfungi of Leucostoma and Valsa genera and their Cytospora anamorphs on arboreal plants in the steppe zone of Southern Russia // Actual problems of ecology: Mater. IV All-Russian Science Conference in Vladikavkaz, North Ossetian State University: 40-45 (in Russian).

Bull JJ, Huelsenbeck JP, Cunningham CW, Swofford DL, Waddell PJ. 1993 - Partitioning and combining data in phylogenetic analysis. Systematic Biology 42, 384-397.

Cai L, Hyde KD, Taylor PWJ, Weir BS et al. 2009 - A polyphasic approach for studying Colletotrichum. Fungal Diversity 39, 183-204.

Carbone I, Kohn LM. 1999 - A method for designing primer sets for speciation studies in filamentous ascomycetes. Mycologia 91, 553-556.

Castlebury, L.A., Rossman, A.Y., Jaklitsch, W.J. \& Vasilyeva, L.N. 2002 - A preliminary overview of Diaporthales based on large subunit nuclear ribosomal DNA sequences. Mycologia 94, 1017-1031.

Chomnunti P, Hongsanan S, Hudson BA, Tian Q et al. 2014 - The sooty moulds. Fungal Diversity $66,1-36$.

Cunningham CW. 1997 - Can three incongruence tests predict when data should be combined? Molecular Biology and Evolution 14, 733-740.

Dayarathne MC, Boonmee S, Braun U, Crous PW et al. 2016 -Taxonomic utility of old names in current fungal classification and nomenclature: Conflicts, confusion \& clarifications. Mycosphere 7, 1622-1648.

Défago G. 1942 - Seconde contributionále connaissance des Valśeesv. H. Phytopathologische Zeitschrift 14, 103-147.

Doilom M, Dissanayake AJ, Wanasinghe DN, Boonmee S et al. 2017 - Microfungi on Tectona grandis (teak) in Northern Thailand. Fungal Diversity 82, 107-182.

Ehrenberg CG. 1818 - Sylvae Mycologicae Berolinenses. Formis Theophili Bruschcke, Berlin, Germany. [In Latin]

Fan XL, Liang YM, Ma R, Tian CM. 2014 - Morphological and phylogenetic studies of Cytospora (Valsaceae, Diaporthales) isolates from Chinese scholar tree, with description of a new species. Mycoscience 55, 252-259.

Fan XL, Hyde KD, Liu M, Liang YM, Tian CM. 2015a - Cytospora species associated with walnut canker disease in China, with description of a new species C. gigalocus. Fungal Biology 119, 310-319.

Fan XL, Hyde KD, Yang Q, Liang YM et al. 2015b - Cytospora species associated with canker disease of three antidesertification plants in northwestern China. Phytotaxa 197, 227-244.

Farris JS, Källersjö M, Kluge AG, Bult C. 1995a - Constructing a significance test for incongruence. Systematic Biology 44, 570-572.

Farris JS, Källersjö M, Kluge AG, Bult C. 1995b - Testing significance of incongruence. Cladistics $10,315-319$.

Felsenstein J. 1985 - Confidence limits on phylogenies: An approach using the bootstrap. Evolution 39, 783-791.

Fotouhifar KB, Hedjaroude GA, Leuchtmann A. 2010 - ITS rDNA phylogeny of Iranian strains of Cytospora and associated teleomorphs. Mycologia 102, 1369-1382.

Fries EM. 1823 - Systema mycologicum vol 2. Greifswald, Germany. [In Latin]

Gvritishvili MN. 1973 - Cytospora kantschavelii Gvrit. Mikologia Fitopatologia 7, 547 (in Russia).

Gvritishvili MN. 1982 - The fungal genus Cytospora in the USSR. Sabchota Sakarstvelo, Tbilisi (in Russia).

Huang F, Chen GQ, Hou X, Fu YS, Cai L, Hyde KD, Li HY. 2013 - Colletotrichum species associated with cultivated citrus in China. Fungal Diversity 61, 61-74.

Hyde KD, Abd-Elsalam K, Cai L. 2010 - Morphology: still essential in a molecular world. Mycotaxon 114, 439-451.

Hyde KD, Cai L, Cannon PF, Crouch JA et al. 2009 - Colletotrichum - names in current use. Fungal Diversity 39, 147-183. 
Hyde KD, Nilsson RH, Alias SA, Ariyawansa HA et al. 2014 - One stop shop: backbones trees for important phytopathogenic genera: I. Fungal Diversity 67, 21-125.

Hyde KD, Hongsanan S, Jeewon R, Bhat DJ et al. 2016 - Fungal diversity notes 367-490: taxonomic and phylogenetic contributions to fungal taxa. Fungal Diversity 80, 1-270.

Index Fungorum 2017 - www.indexfungorum.org.

Jayasiri SC, Hyde KD, Abd-Elsalam KA, Abdel-Wahab MA et al. 2015 - The faces of fungi database: fungal names linked with morphology, molecular and human attributes. Fungal Diversity 74, 3-18.

Jeewon R, Hyde KD 2016 - Establishing species boundaries and new taxa among fungi: recommendations to resolve taxonomic ambiguities. Mycosphere 7, 1669-1677.

Kirk PM, Cannon PF, Minter DW, Stalpers JA. 2008 - Ainsworth \& Bisby's dictionary of the fungi, 10th edn. CABI, Wallingford.

Kishino H, Hasegawa M. 1989 - Evaluation of the maximum likelihood estimate of the evolutionary tree topologies from DNA sequence data, and the branching order in Hominoidea. Journal of Molecular Evolution 29, 170-179.

Kumar S, Stecher G, Tamura K. 2015 - MEGA7: Molecular Evolutionary Genetics Analysis version 7.0. Molecular Biology and Evolution 33, 1870-1874.

Li GJ, Hyde KD, Zhao RN, Hongsanan S et al. 2016 - Fungal Divers notes 253-366: taxonomic and phylogenetic contributions to fungal taxa. Fungal Diversity 78, 1-237.

Liu JK, Hyde KD, Jones EBG, Ariyawansa HA et al. 2015 - Fungal Diversity Notes 1-110: Taxonomic and phylogenetic contributions to fungal species. Fungal Diversity 72, 1-197.

Lombard L, Houbraken J, Decock C, Samson RA et al. 2016 - Generic hyper-diversity in Stachybotriaceae. Persoonia 36, 156-246.

Maharachchikumbura SSN, Guo LD, Chukeatirote E, Bahkali AH, Hyde KD. 2011 Pestalotiopsis-morphology, phylogeny, biochemistry and diversity. Fungal Diversity 50, 167-187

Maharachchikumbura SSN, Guo LD, Cai L et al. 2012 - A multi-locus backbone tree for Pestalotiopsis, with a polyphasic characterization of 14 new species. Fungal Diversity 56, 95-129

Maharachchikumbura SSN, Hyde KD, Jones EBG, McKenzie EHC et al. 2015 - Towards a natural classification and backbone tree for Sordariomycetes. Fungal Diversity 72, 199-301

Maharachchikumbura SSN, Hyde KD, Jones EBG, McKenzie EHC et al. 2016 - Families of Sordariomycetes. Fungal Diversity 72, 199-301.

Matheny PB. 2005 - Improving phylogenetic inference of mushrooms with RPB1 and RPB2 nucleotide sequences (Inocybe; Agaricales). Molecular Phylogenetics and Evolution 35, 120.

Mapook A, Boonmee S, Ariyawansa HA, Tibpromma S et al. 2016 - Taxonomic and phylogenetic placement of Nodulosphaeria. Mycological Progress 15, 34

McNeill J, Barrie FR, Buck WR, et al. 2012 - International code of nomenclature for Algae, Fungi, and Plants (Melbourne Code). Regnum Veg 154.

Mehrabi M, Mohammadi Goltapeh E, and Fotouhifar KB. 2011 - Studies on Cytospora canker disease of apple trees in Semirom region of Iran. Journal of Agricultural Technology 2011 Vol. 7, 967-982.

Norphanphoun C, Maharachchikumbura SSN, Daranagama A, Bulgakov TS et al. 2015 - Towards a backbone tree for Seimatosporium, with S. physocarpi sp. nov. Mycosphere 6, 385-400.

Norphanphoun C, Hongsanan S, Doilom M, Bhat DJ et al. 2016 - Lamproconiaceae fam. nov. to accommodate Lamproconium desmazieri. Phytotaxa 270, 089-102.

Nylander JAA. 2004 - MrModeltest 2.0. Program distributed by the author. Evolutionary Biology Centre, Uppsala University.

O’Donnell K. 1993 - Fusarium and its near relatives. Wallingford, UK.

Rambaut A. 2012 - Fig.Tree. Tree Figure Drawing Tool, version 1.4.0 [computer program]. Available from: http://tree.bio.ed.ac.uk/ software/figtree/ (Accessed 23 May 2016) 
Rambaut A, Suchard MA, Xie D, Drummond AJ. 2013 - Tracer v1.6, http://beast.bio.ed.ac.uk/software/tracer/ (Accessed 09 August 2016)

Ronquist F, Teslenko M, van der Mark P, Ayres DL et al. 2012 - MrBayes 3.2: efficient Bayesian phylogenetic inference and model choice across a large model space. Systematic Biology 61, 539-542.

Rossman AY, Adams GC, Cannon PF, Castlebury LA et al. 2015 - Recommendations of generic names in Diaporthales competing for protection or use. IMAFungus 6, 145-154.

Saccardo PA. 1884 - Sylloge Fungorum vol 3. Typis Seminarii, Italy. [In Latin]

Silvestro D, Michalak I. 2012 - raxmlGUI: a graphical front-end for RAxML. Organisms Diversity \& Evolution 12, 335-337.

Singh MP, Janso JE, Brady SF. 2007 - Cytoskyrins and Cytosporones produced by Cytospora sp. CR200: taxonomy, fermentation and biological activities. Marine Drugs 5, 71-84.

Sivanesan A, Holliday P. 1970 - Valsa eugeniae. In 'CMI Descriptions of Pathogenic Fungi and Bacteria', No. 230. (CAB International: Surrey)

Smith H, Wingfield MJ, Petrini O. 1996 - Botryosphaeria dothidea endophytic in Eucalyptus grandis and Eucalyptus nitens in South Africa. Forest Ecology and Management 89, 189195.

Spielman LJ. 1983 - Taxonomy and Biology of Valsa Species on Hardwoods in North America, with Special Reference to Species on Maples. Cornell University, NY, USA.

Spielman LJ. 1985 - A monograph of Valsa on hardwoods in North America. Canadian Journal of Botany 63, 1355-1378.

Stamatakis E. 2006 - RAxML-VI-HPC: maximum likelihood-based phylogenetic analyses with thousands of taxa and mixed models. Bioinformatics 22, 2688-2690.

Swofford DL. 2003 - PAUP: phylogenetic analysis using parsimony, (*and other methods). Version 4.0 b10. Sinauer Associates, Sunderland MA.

Udayanga D, Castlebury LA, Rossman AY, Chukeatirote E, Hyde KD. 2014 - Insights into the genus Diaporthe: phylogenetic species delimitation in the D. eres species complex. Fungal Diversity 67, 203-229.

Udayanga D, Castlebury LA, Rossman AY, Chukeatirote E, Hyde KD. 2015 - The Diaporthe sojae species complex: phylogenetic reassessment of pathogens associated with soybean, cucurbits and other field crops. Fungal Biology 119, 383-407.

Udayanga D, Liu XZ, McKenzie EHC, Chukeatirote E, Bahkali AHA, Hyde KD. 2011 - The genus Phomopsis: biology, applications, species concepts and names of common phytopathogens. Fungal Diversity 50, 189-225.

Wang XL, Kang ZS, Huang LL, Wei J. 2011 - Re-evaluation of pathogens causing Valsa canker on apple in China. Mycologia 103, 317-324.

Wang YL, Lu Q, Decock C, Li YX, Zhang XY. 2015 - Cytospora species from Populus and Salix in China with C. davidiana sp. nov. Fungal Biology 119, 420-432.

Wei JG, Phan CK, Wang L, Xu T et al. 2013 - Pestalotiopsis yunnanensis sp. nov., an endophyte from Podocarpus macrophyllus (Podocarpaceae) based on morphology and ITS sequence data. Mycological Progress 12, 563-568.

Wikee S, Udayanga D, Crous PW, Chukeatirote E et al. 2011 - Phyllosticta-an overview of current status of species recognition. Fungal Diversity 51, 43-61.

Yang Q, Fan ZL, Crous PW, Liang YM, Tian CM. 2015 - Cytospora from Ulmus pumila in Northern China. Mycological Progress 14, 74. 